\title{
O Patrocínio no Futebol Feminino
}

\author{
Mariana Bergier
}

TRABALHO DE CONCLUSÃO DO CURSO

CENTRO DE CIÊNCIAS SOCIAIS - CCS DEPARTAMENTO DE ADMINISTRAÇÃO

Graduação em Administração de Empresas 
Mariana Bergier

\section{O Patrocínio no Futebol Feminino}

\section{Trabalho de Conclusão de Curso}

Trabalho de Conclusão de Curso, apresentado ao programa de graduação em Administração da PUC-Rio, como requisito parcial para a obtenção do título de graduação em Administração.

Orientador (a): André Lacombe Penna da Rocha

Rio de Janeiro, junho de 2021 


\section{O Patrocínio no Futebol Feminino}

MARIANA ALENCAR BERGIER

André Lacombe Penna da Rocha

\section{Agradecimentos}

Primeiramente, gostaria de agradecer aos meus pais, Marcelo e Lucille, que me deram suporte e apoio para seguir todos os meus sonhos e atingir meus objetivos durante toda a minha trajetória como estudante da PUC Rio.

A minha família e amigos, que estiveram ao meu lado ao longo de toda essa jornada. Um agradecimento especial a Sharon Nigri, que me ajudou e motivou a escolher o tema, me passando todo o seu conhecimento como profissional da área.

Ao André Lacombe, orientador da pesquisa, que aceitou o desafio e me incentivou todos os dias a fazer um trabalho de excelência.

A todos os entrevistados, por doarem seu tempo para compartilhar os seus conhecimentos sobre o tema escolhido, sendo fundamentais para a realização dessa pesquisa e para enfatizar a importância do assunto.

Por fim, a PUC-Rio, por me fazer capaz de realizar esse estudo, me dar toda a base necessária e me preparar para o mercado com os melhores professores possíveis. 


\section{Resumo}

Este trabalho tem como objetivo encontrar explicações do porquê o futebol feminino brasileiro receber tão menos atenção e recursos em comparação com a modalidade masculina. Como resultado, pretende-se encontrar argumentos que auxiliem no aumento da visibilidade e competitividade da modalidade feminina no Brasil. Foi utilizado o método Delphi, com a finalidade de conhecer as opiniões dos especialistas e a partir das rodadas de interações encontrar algum nível de consenso entre suas visões, alcançando assim o objetivo do trabalho. Os resultados permitiram uma melhor compreensão do cenário do patrocínio no futebol feminino brasileiro, onde é possível visualizar uma grande evolução nos últimos anos, principalmente a partir da Copa do Mundo de 2019. No que diz respeito à comparação com a categoria masculina, a visibilidade e o retorno que cada uma categoria traz são as principais diferenças encontradas. Além disso, destaca-se que a diferença de oportunidades, recursos e infraestrutura que caracterizam a distância entre o futebol masculino e o feminino, no Brasil, é fruto de uma construção histórica, em parte com embasamento legal, em parte reflexo de uma sociedade machista há vários séculos.

Palavras-chave: Esporte, Futebol, Futebol feminino, Marketing Esportivo e Patrocínio esportivo. 


\begin{abstract}
This paper aims to find explanations for why Brazilian women's football receives so much less attention and resources compared to men's football. As a result, it is intended to find arguments that help to increase the visibility and competitiveness of the female sport in Brazil. The Delphi method was used in order to know the opinions of experts and from the rounds of interactions to find some level of consensus between their views, thus achieving the objective of the work. The results allowed a better understanding of the sponsorship scenario in Brazilian women's football, where it is possible to see a great evolution in recent years, especially since the 2019 World Cup. Regarding the comparison with the male category, visibility and the return that each category brings are the main differences found. In addition, it is noteworthy that the difference in opportunities, resources and infrastructure that characterize the distance between men's and women's football in Brazil is the result of a historical construction, in part with a legal basis, in part a reflection of a sexist society for several centuries.
\end{abstract}

Keywords: Sports, Football, Women's Football, Sports Marketing and Sports Sponsorship. 


\section{Sumário}

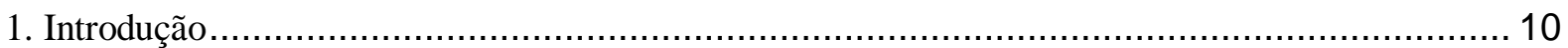

1.1 Introdução ao tema e ao problema do estudo................................................................. 10

1.2 Um breve histórico do futebol feminino no Brasil ............................................................... 10

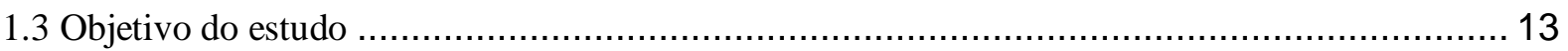

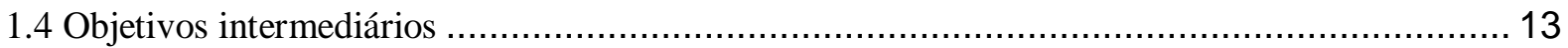

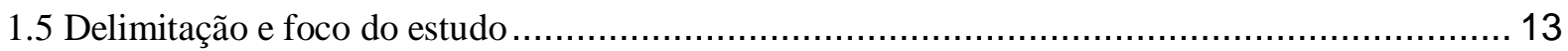

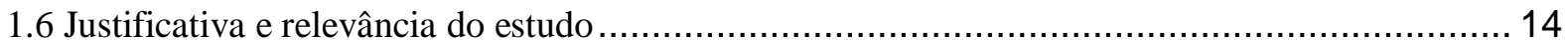

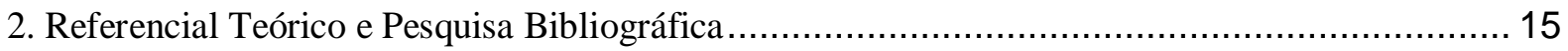

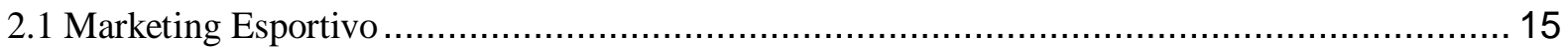

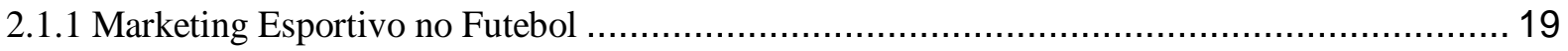

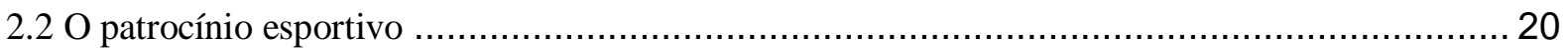

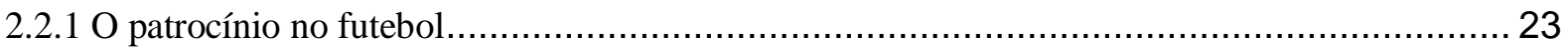

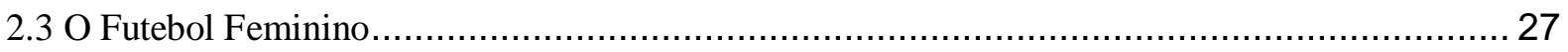

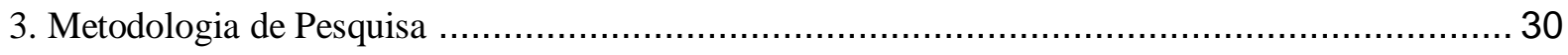

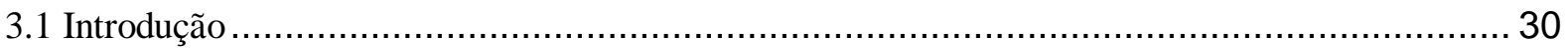

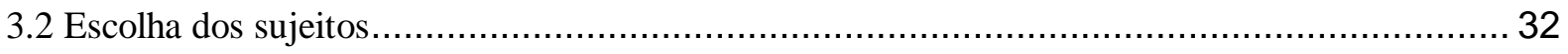

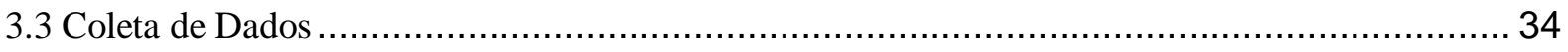

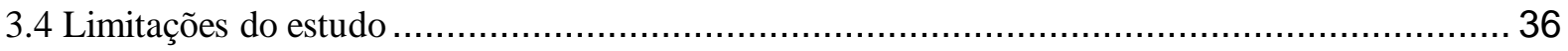

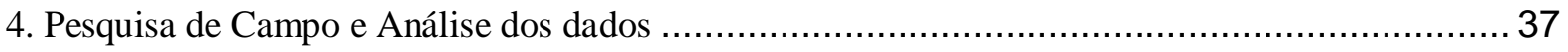

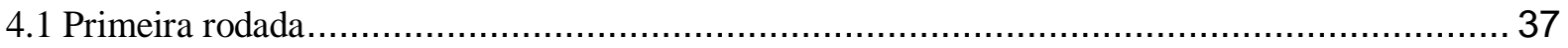

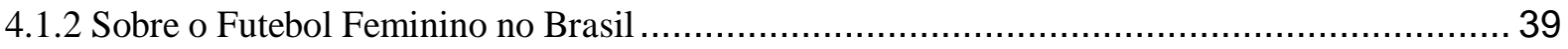

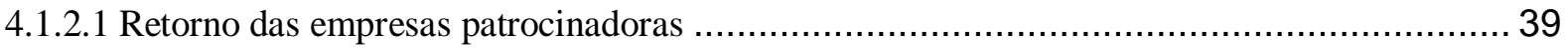

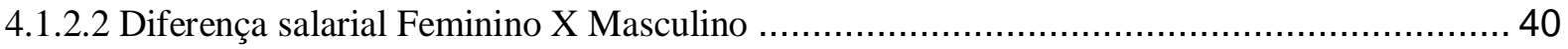

4.1.2.3 Papel da imprensa e dos veículos de comunicação........................................................ 44

4.1.2.4 Subvalorização dos patrocínios na modalidade feminina .............................................. 47

4.1.2.5 Ações de patrocínio por parte da iniciativa privada.................................................... 50

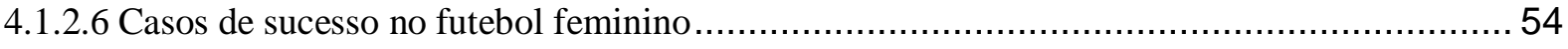

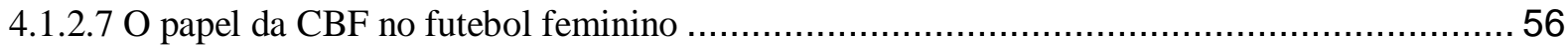

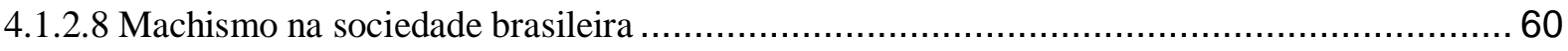

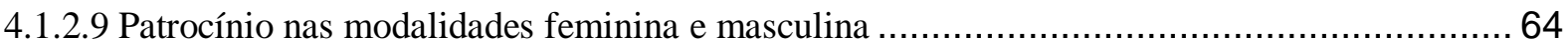

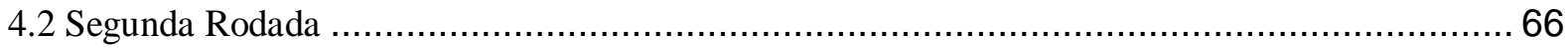

4.2.1 Diferença salarial entre atletas dos gêneros feminino e masculino.................................... 67

4.2.2 Subvalorização dos patrocínios na modalidade feminina................................................. 69 
4.2.3 Ações de patrocínio por parte da iniciativa privada 70

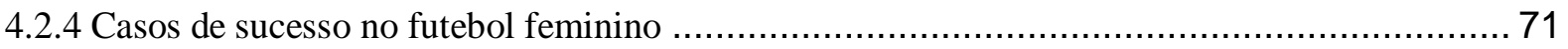

4.2.5 Patrocínio nas modalidades feminina e masculina de futebol ............................................. 73

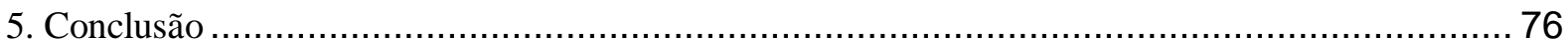

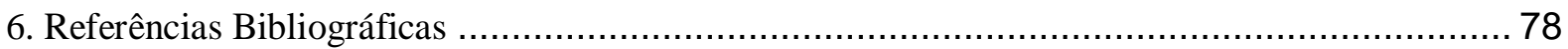

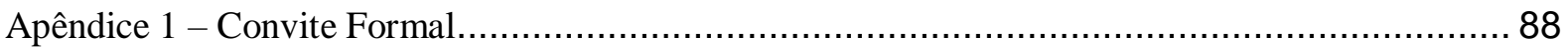

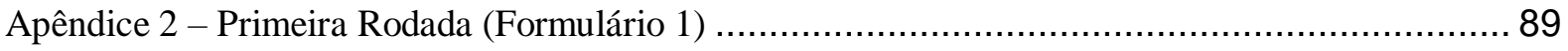

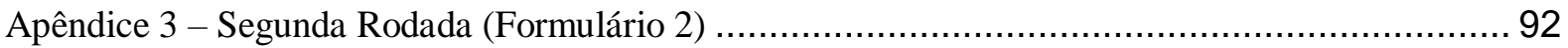




\section{Lista de Figuras}

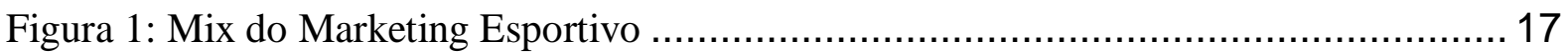

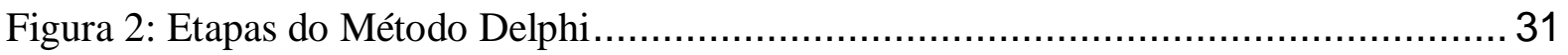




\section{Lista de Tabelas}

Tabela 1: Perfil do Respondente 38

Tabela 2: Tipos de retorno das empresas com patrocínio do futebol feminino ….......................... 40

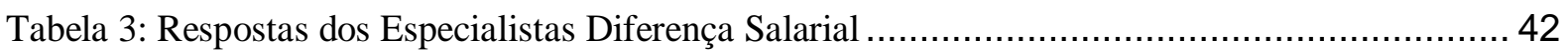

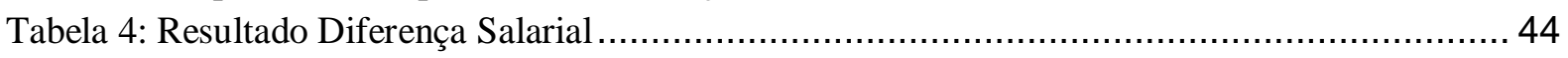

Tabela 5: Avaliação da cobertura da imprensa e veículos de comunicação em geral da modalidade

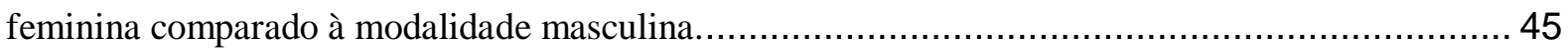

Tabela 6: Nível de Importância das mídias para o desenvolvimento da modalidade ....................... 46

Tabela 7: Evolução das mídias nos últimos anos............................................................. 47

Tabela 8: Respostas dos Especialistas sobre a Subvalorização dos Patrocínios na Modalidade

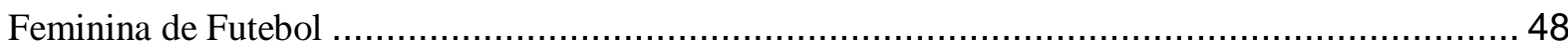

Tabela 9: Resultado Subvalorização dos Patrocínios ............................................................ 50

Tabela 10: Respostas dos Especialistas em Relação à Ações da Iniciativa Privada (Guaraná

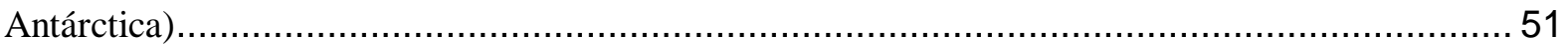

Tabela 11: Resultado dos Especialistas em Relação à Ações da Iniciativa Privada (Guaraná

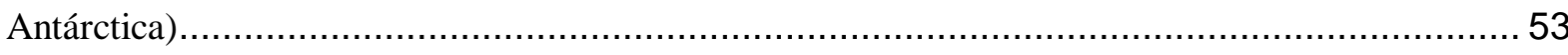

Tabela 12: Respostas dos Especialistas sobre os Casos de Sucesso Ferroviária e Corinthians. ......... 54

Tabela 13: Resultado dos Especialistas sobre os Casos de Sucesso Ferroviária e Corinthians. ......... 56

Tabela 14: Respostas dos Especialistas a respeito da Imposição feita pela CBF ..........................5 57

Tabela 15: Resultado dos Especialistas a respeito da Imposição feita pela CBF .............................60

Tabela 16: Respostas dos Especialistas sobre Existência de Machismo no Futebol......................... 61

Tabela 17: Resultado dos Especialistas sobre Existência de Machismo no Futebol........................ 63

Tabela 18: Respostas dos Especialistas sobre as Diferenças do Patrocínio entre as Modalidades

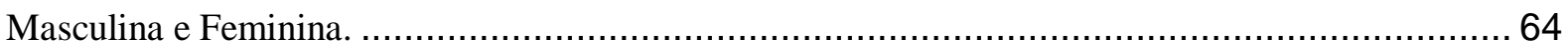

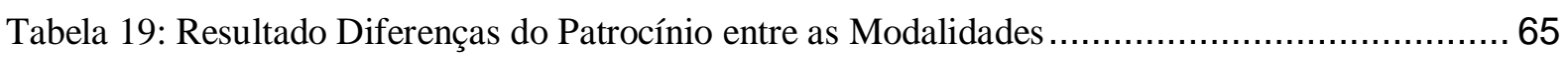

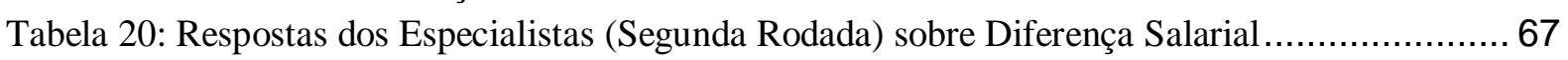

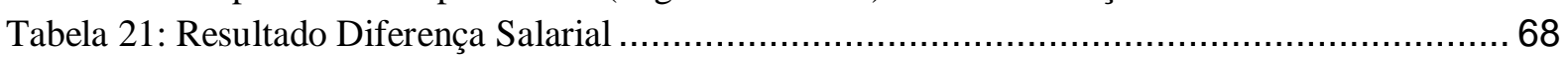

Tabela 22: Respostas dos Especialistas (Segunda Rodada) - Subvalorização dos Patrocínios .......... 69

Tabela 23: Resultado sobre a Subvalorização dos Patrocínios da Modalidade Feminina do Futebol . 70

Tabela 24: Respostas dos Especialistas (Segunda Rodada) -Ações Iniciativa Privada ..................... 71

Tabela 25: Respostas dos Especialistas (Segunda Rodada) - Casos de Sucesso ............................. 71

Tabela 26: Resultado sobre os Casos de Sucesso no Futebol Feminino no Brasil ............................ 72

Tabela 27: Respostas dos Especialistas (Segunda Rodada) - Diferenças do Patrocínio entre as

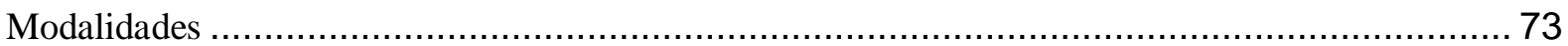

Tabela 28: Resultado Final sobre Diferenças do Patrocínio entre as Modalidades de Gênero............ 74 


\section{Introdução}

\subsection{Introdução ao tema e ao problema do estudo}

O futebol começou a ser praticado no Brasil em 1894, quando Charles Miller, vindo da Inglaterra, trouxe o esporte para o país. Considerado o país do futebol, ele é o único a disputar todas as 21 edições da Copa do Mundo, além de ser o país com o maior número de títulos da competição de seleções mais importante do mundo (FRANCO, 2017). Campeão em 1958, na Suécia; 1962, no Chile; 1970, no México; 1994, nos Estados Unidos, e 2002 na Copa da Coreia e Japão. Além disso, destaca-se o Rei do futebol brasileiro, Pelé, famoso por ter vencido três desses títulos, além de ter um recorde mundial de 1.281 gols em 1.363 jogos pelo clube (DUARTE, 2020).

O futebol no Brasil se desenvolveu como uma maneira de socialização tradicionalmente destinada à população masculina. Quando se trata do futebol feminino, no entanto, ele ainda caminha por um longo trajeto na busca por uma visibilidade merecida. A cultura do país, o apoio, o lucro, a inspiração e a paixão, estão ligados à modalidade masculina (PAIXÃO, 2017). Para se introduzir ao problema são trazidas algumas perguntas: Quantos já assistiram algum jogo da seleção feminina brasileira de futebol feminino? Quantos conhecem as jogadoras que jogam dentro e fora do país? E os times de futebol feminino? Para finalizar, o que explica a diferença de salário da Marta, seis vezes eleita pela FIFA como a melhor jogadora de futebol no mundo, com a de Neymar?

\subsection{Um breve histórico do futebol feminino no Brasil}

Getúlio Vargas, em 1941, assinou um decreto que afirmava que "às mulheres não se permitirá a prática de desportos incompatíveis com as condições de sua natureza" (FERRARI; CAIADO, 2019). Pois essas "condições de sua natureza" incluíam a prática do futebol. Foi apenas em 1979 que essa proibição deixou de existir e somente em 1993 começaram a surgir os primeiros times profissionais, como São Paulo, Santos e Rio de Janeiro. Dentro deles é possível constatar ainda, a carência de apoio, de infraestrutura, de patrocínio, as consequentes dificuldades financeiras e sua baixa visibilidade (PAIXÃO, 2017).

Entretanto, no Brasil, o futebol feminino é uma modalidade que vem ganhando mais espaço nas mídias de comunicação. Porém, ainda são visíveis as grandes e diversas diferenças quando comparado ao masculino (ALMEIDA, 2019). Antigamente, as meninas 
eram culturalmente educadas para praticar outras atividades esportivas, sendo geralmente o futebol o último dessa lista (SOUSA; ALTMANN, 1999). Atualmente, é possível identificar uma pequena evolução neste quadro, onde o futebol já faz parte da rotina de muitas meninas. Segundo dados do Ministério do Esporte (2019), a maioria dos meninos no Brasil começa a praticar esportes a partir dos 5 anos de idade. Para as meninas, esse primeiro contato acontece após os 11 anos (ELLER, 2019).

Em relação à Copa do Mundo, maior evento de futebol, a primeira edição do torneio feminino aconteceu em 1991, na China, com a participação de apenas 12 seleções (MONALISA CEOLIN, 2019). Já na modalidade masculina, o campeonato acontece desde 1930.

A última edição do campeonato mundial feminino ocorreu na França, em 2019, onde, por parte da FIFA, houve um aumento do prêmio geral a ser distribuído para as seleções participantes, assim como um aumento do prêmio das vencedoras da competição, pontos que serão abordados com uma maior atenção adiante. Ademais, neste evento houve o recorde de ingressos vendidos e a transmissão em canais nacionais ao vivo dos jogos, conforme também visto com maiores detalhes a seguir (CEOLIN, 2019).

Quando analisadas as diferenças entre as modalidades masculina e feminina no futebol, a primeira delas, e provavelmente a mais evidente, é relacionada aos salários. Enquanto no futebol masculino os homens podem ostentar e desfrutar de seus salários, as mulheres lutam para encontrar um time financeiramente sólido, fazendo com que muitas desistam da profissão ao longo dessa batalha.

Segundo dados da CBF Academy (2020), o prêmio geral para a Copa do Mundo feminina, em 2019, foi de 30 milhões de dólares, enquanto a masculina foi de 400 milhões de dólares. De acordo com Ceolin (2019), Entidade das Nações Unidas para a Igualdade de Gênero e o Empoderamento das Mulheres (UN WOMEN), o salário anual do renomado jogador argentino Lionel Messi em 2018 foi duas vezes superior à soma dos salários das 1693 jogadoras das sete principais ligas de futebol feminino mundiais naquele ano (CEOLIN, 2019).

Outro ponto a ser ressaltado se refere aos valores de contratos de patrocínio. Patrocínios têm assumido posições de destaque dentre as ferramentas de marketing esportivo. A partir deles empresas buscam ativar ações estratégicas como formas de melhorar o seu desempenho mercadológico: visibilidade, associações de imagem e reconhecimento, entre outros. O 
patrocínio é considerado uma das atividades promocionais de marketing que mais se desenvolveu nos últimos anos (IEG, 2018).

A título de ilustração, em 2017 os investimentos em patrocínio chegaram ao patamar de U\$62,7 bilhões no mundo, e nos Estados Unidos, principal mercado deste tipo de ação, alcançou o montante de U\$23,1 bilhões, sendo aproximadamente setenta por cento do total destinado ao esporte (IEG, 2018).

Segundo o site Marketing Esportivo (2021), em 2021 a Nike vai manter a liderança no ranking dos maiores patrocinadores esportivos no mundo, com um investimento estimado em U\$1,6 bilhão, distribuídos principalmente nas três principais ligas do mercado americano: NFL, NBA e MLB. Em segundo lugar estima-se ser a marca Adidas, que investirá algo como $\mathrm{R} \$ 1,3$ bilhão, sendo $73 \%$ deste total destinado ao futebol.

Segundo o International Events Group (IEG, 2018), no que tangem os investimentos em ações promocionais de marcas no mundo dos esportes, nos últimos anos a tendência tem sido um maior esforço em iniciativas envolvendo o patrocínio, enquanto a publicidade e a promoção de vendas têm ficado em segundo plano. Ainda segundo esta fonte, os principais objetivos almejados pelos patrocinadores ao realizarem um patrocínio esportivo são: dar visibilidade à marca, elevar lealdade à marca, alterar ou reforçar a imagem de marca, elevar a circulação de pessoas nos pontos-de-venda, estimular vendas e experimentações de produtos, demonstrar responsabilidade social, distribuir, exibir e demonstrar produtos e construir relacionamentos com os clientes.

A despeito das referências listadas acima, a crescente utilização do patrocínio esportivo parece que não acontece de maneira equânime entre as modalidades masculina e feminina (SHAW; AMIS, 2001). De fato, historicamente o esporte tem sido mais associado ao universo masculino, refletindo diretamente na esfera de negócios do esporte, especificamente em relação ao patrocínio esportivo e às premiações financeiras (UNITED NATIONS, 2007).

Para atenuar essa diferença, em 2019, a marca Guaraná Antarctica, patrocinadora das seleções brasileiras masculina e feminina de futebol há 18 anos, assumiu o papel de um bom treinador e iniciou uma busca por um time de empresas para apoiar o futebol feminino. Ou seja, a marca buscou incentivar outras empresas a abrirem suas portas para as jogadoras, convocando algumas atletas da seleção brasileira feminina para a campanha (BRANDÃO, 2019). Embora tal medida seja merecedora de reconhecimento e apreço, a questão é: por que, já no século XXI, 
ainda se fazem necessárias ações deste tipo para que o esporte e as atletas femininas tenham as devidas condições para prosperar em suas profissões? Esta e outras questões correlatas motivam o presente trabalho.

\subsection{Objetivo do estudo}

Com base no exposto, o objetivo do presente estudo é encontrar explicações do porquê o futebol feminino brasileiro receber tão menos atenção e recursos em comparação com a modalidade masculina. Como resultado, pretende-se encontrar argumentos que auxiliem no aumento da visibilidade e competitividade da modalidade feminina no Brasil.

\subsection{Objetivos intermediários}

Para se atingir o objetivo final proposto, este estudo prevê, como objetivos intermediários a serem alcançados o seguinte:

- Identificar quais são as marcas patrocinadoras do futebol feminino e do masculino e pontuar algumas ações realizadas por elas.

- Levantar quais são os papéis dos órgãos reguladores, como a CBF e a FIFA em relação ao auxílio na organização, realização, promoção/divulgação da modalidade feminina de futebol no Brasil e elencar quais medidas estão sendo tomadas ao longo dos anos para desenvolver a modalidade feminina.

\subsection{Delimitação e foco do estudo}

O futebol é considerado o esporte mais popular do planeta, com mais de 300 mil clubes de futebol oficializados, estimados 3 bilhões de praticantes e 3,5 bilhões de torcedores no mundo (MAIS BOLSAS, 2021). O trabalho terá como foco a modalidade esportiva do futebol feminino.

O foco do trabalho será limitado ao Brasil. Apesar do Brasil apresentar diversos times de futebol feminino, a falta de informações pode ser considerada um obstáculo para um estudo completo. Dessa forma, serão estudados dois times de relevância na modalidade feminina, além da seleção brasileira, com a finalidade de ter uma visão mais geral do esporte. 


\subsection{Justificativa e relevância do estudo}

Conforme falado anteriormente, este estudo tem como objetivo de encontrar explicações do porquê o futebol feminino brasileiro receber tão menos atenção e recursos em comparação com a modalidade masculina. Ou seja, levantar as razões pelas quais os experts acreditam que a modalidade feminina vem sendo menos privilegiada do que a masculina. Uma razão histórica de fundo legal, extinta. Outra histórica de fundo preconceituoso e machista. Ademais, há também uma explicação relacionada à "qualidade dos produtos", campeonatos pouco atraentes etc., além da questão da menor visibilidade e consequentemente um retorno inferior em comparação à modalidade masculina.

As informações que este estudo pretende produzir podem se mostrar de interesse para diversos públicos, a começar pelas marcas patrocinadoras. É muito importante que elas compreendam a situação do futebol feminino no Brasil, identificando o enorme potencial que essa modalidade possui. Sendo a maioria da população brasileira composta do gênero feminino, além da existência de jogadoras como referências e muitas outras atletas com excelentes performances no âmbito internacional, é evidente que esse mercado tem muito a ser desenvolvido e aproveitado pelas marcas.

As empresas que possuem o seu público-alvo vão conseguir visualizar a oportunidade de utilizarem o futebol feminino como uma forma de veiculação para a apresentação de novos produtos, por exemplo. Dessa forma, há muito a ser feito, o que representam oportunidades para aqueles que se envolverem na modalidade, podendo servir de estímulo, referência e inspiração a novas atletas, surgindo uma modalidade vencedora e popular.

Por fim, sob a ótica acadêmica, este trabalho pretende abrir novas frentes de análise para o patrocínio do futebol feminino no Brasil, ao estudar quais os principais fatores que influenciam no processo decisório de uma empresa patrocinar um time. É evidente a necessidade de ampliação de artigos acadêmicos abordando o patrocínio no futebol feminino. 


\section{Referencial Teórico e Pesquisa Bibliográfica}

Neste capítulo serão abordados os conceitos associados ao tema, começando pela definição de marketing esportivo, em seguida descrevendo a lógica do patrocínio, seu papel no esporte, no futebol e no futebol feminino em especial, sendo este o destaque neste trabalho.

\subsection{Marketing Esportivo}

$\mathrm{O}$ marketing tornou-se uma ferramenta fundamental para as organizações que desejam se inserir ou se manter em seus mercados atualmente, visto que o mundo está cada vez mais competitivo. De acordo com Kotler (1997), marketing implica o uso de recursos de uma organização objetivando suprir as necessidades e desejos do consumidor, a fim de criar valor e oferecer as satisfações desejadas, de forma mais eficiente que seus concorrentes. É a relação social de criação, oferta e negociação de um produto ou serviço no mercado, onde eles são adquiridos por indivíduos ou grupos.

De acordo com Rocha, Ferreira \& Silva (2012) marketing é uma orientação da administração, que reconhece que a tarefa primordial da organização é proporcionar maior satisfação ao consumidor, atendendo às suas necessidades, levando em conta seu bem-estar no longo prazo, respeitadas as exigências e limitações impostas pela sociedade e atendidas as necessidades de sobrevivência e continuidade da organização (Rocha et al. 2012, p. 4).

Para a Churchill e Peter (2000), o processo do marketing também está voltado para planejar e executar a concepção, as definições de preços, promoção e distribuição com o objetivo de criar trocas para satisfazer tanto a organização quanto os clientes.

Com a crescente exigência dos consumidores, e consequentemente uma concorrência cada vez maior, as empresas estão tendo de investir em estratégias para se diferenciarem dos seus concorrentes, além de buscarem meios para a consolidação de uma marca, elevando assim a probabilidade de vendas e do potencial fidelização de seus consumidores. Dentro desse cenário, destaca-se o marketing esportivo, ações relacionadas ao esporte e aos produtos e serviços ligados a ele (LORDELLO, 2013).

O marketing esportivo é o processo de formatação e implementação de atividades de produção, precificação, promoção, e distribuição de um produto esportivo para satisfazer os desejos de consumidores e alcançar os objetivos da organização (PITTS e STOTLAR, 2007). 
Segundo Afif (2000), as empresas utilizam o momento de lazer dos espectadores para fazerem promoções de seus produtos e serviços.

Marketing esportivo envolve tudo que está ligado a um evento esportivo, como divulgação de modalidades esportivas, clubes e associações, patrocínio de equipes, atletas e/ou de torneios, licenciamento e merchandising, propagandas, gestão de atletas, desenvolvimento de produtos esportivos, monitoramento de mídia esportiva, desenvolvimento de pesquisas de marketing esportivo, entre outras atividades (BERTOLDO, 2000). Ou seja, todas as atividades designadas a satisfazer as necessidades e desejos dos consumidores esportivos através de processos de troca, desenvolvendo dois eixos principais: o marketing de produtos e serviços esportivos, diretamente para os consumidores esportivos, e o marketing de outros produtos e serviços, através da utilização das promoções esportivas (MULLIN et al., 2004, p. 18).

Pitts e Stotlar (2002) complementam a lista dos produtos oferecidos pela indústria do esporte incluindo em sua descrição: esportes oferecidos como produto de participação (liga de basquete recreativo para mulheres), equipamentos e acessórios necessários ou desejados na prática de atividades esportivas (uniformes, joelheiras e demais acessórios), brindes promocionais usados para promover esportes, eventos esportivos ou atividades de fitness (bonés e toalhas de academias), serviços de uma forma geral (encordoamento de raquetes de tênis e limpeza de tacos de golfe), revistas sobre esportes específicos, etc.

Segundo Melo Neto (2003), seu principal objetivo está relacionado a estabelecer um diferencial capaz de aproximar o consumidor à imagem da marca e do produto com baixo risco, custo menor e margem de êxito ampliada. Além desses, o objetivo do aumento do reconhecimento do público de determinada marca, a intenção de reforçar a imagem da empresa, de estabelecer uma identificação com segmentos específicos do mercado, combater as ações da concorrência, fazer com que a empresa esteja mais envolvida com a sociedade, além de atribuir credibilidade ao produto com a associação à qualidade e emoção do evento (ARAÚJO, 2002).

Dessa forma, o marketing esportivo visa trabalhar com os conceitos de marketing dentro do esporte, ou seja, descreve diversas atividades associadas à promoção do esporte. Algumas vantagens atribuídas ao marketing esportivo relacionam-se a projeção da marca, incremento de credibilidade, ampliação da divulgação de produtos e serviços, 
rejuvenescimento da imagem e venda de produtos com a marca da equipe e do patrocinador (BERTOLDO, 2000).

Para Morgan e Summers (2004), o maior impulso no marketing esportivo foram as Olimpíadas de Los Angeles, em 1934. Essa foi a primeira edição a depender totalmente do dinheiro da iniciativa privada, tendo o patrocínio como uma das formas de investimento no evento. As empresas investiram nesse produto esportivo e fizeram o esporte olímpico virar lucrativo para as organizações.

No Brasil, pesquisas apontam que algumas empresas começaram a investir no esporte na tentativa de obter uma fonte de retorno em imagem e de vendas, no final da década de 70 e começo dos anos 80. A estratégia trouxe os resultados esperados, e atualmente grandes empresas têm seu nome associado ao esporte (CHVINDELMAN, 2001).

A figura abaixo apresenta uma síntese do mix de marketing esportivo na qual aborda que as variáveis produto, preço, promoção e praça estariam relacionadas ao esporte. De acordo com Pitts e Stotlar (2002), a área de marketing deve utilizar os chamados 4Ps para satisfazer o consumidor e atingir os objetivos das instituições envolvidas nas atividades.

Figura 1: Mix do Marketing Esportivo

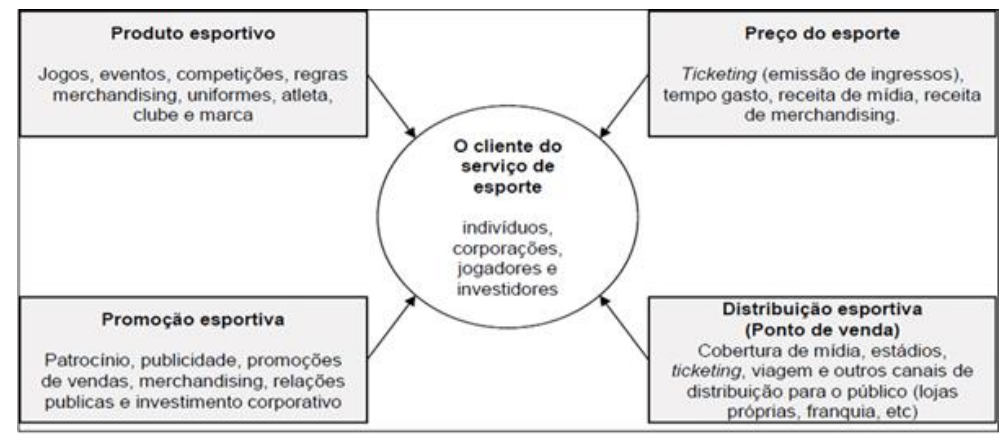

Fonte: Morgan, M. J. \& Summers, J. (2008)

Pitts (2002, p.20) define "o produto esportivo como qualquer bem, serviço, pessoa, lugar ou ideia, com atributos tangíveis e intangíveis, que satisfaz necessidades ou desejos do consumidor quanto a esporte, ginástica e recreação". Ou seja, é aquilo que satisfaz as necessidades dos consumidores. Inclui-se os jogos, eventos, competições, regras de merchandising, uniformes, atleta, clube e marca. 
Para Pozzi (1996, p. 89), o principal produto do marketing esportivo é o esporte em si. E como qualquer outro produto, apresenta aspectos tangíveis, que são o tipo de esporte (futebol, basquetebol, ginástica, entre outros), os participantes, os times e as competições. Além desses, apresenta aspectos intangíveis, como o orgulho, a vibração, a satisfação e a alegria. Em suma, as emoções que envolvem sua realização. Essas emoções movem multidões, o que ajuda a compreender o envolvimento de marcas com o esporte.

Durante o processo da busca pela satisfação das necessidades e desejos dos consumidores é avaliado o custo-benefício das ações a serem implantadas, fazendo com que o preço seja em muitos casos decisivo no momento do investimento. Segundo Pitts (2002, p.99), "a decisão de estabelecer preço para um produto é importante para o profissional de marketing esportivo, porque o preço afeta o sucesso do produto, o status do produto e a percepção do consumidor quanto ao produto". O preço é o que determina a construção da imagem da marca, além de ser a única ferramenta de marketing que gera receita. $\mathrm{O}$ preço no esporte pode ser traduzido como/expresso sob a forma de valor do ticket (ingresso), o tempo gasto, a receita proveniente de mídias (direitos de transmissão ao público) e receitas de merchandising (vendas de artigos complementares).

O ponto de venda está relacionado com os canais de distribuição e os pontos de venda, ou seja, onde e como o produto vai chegar até o consumidor. No esporte inclui-se a distribuição dos sinais de acesso em diferentes formas e coberturas geográficas dos meios de comunicação, escolha dos palcos de realização (estádios, ginásios, outros), acesso aos tickets de ingresso, no caso da presença física, as próprias lojas onde se obtêm os ingressos e os produtos complementares, entre outros. Para a definição desses pontos é necessário avaliar as idiossincrasias do tipo de produto/evento (um jogo de futebol ou a apresentação de um atleta), a infraestrutura necessária e as demandas logísticas, tanto dos consumidores finais, como dos fornecedores e atores (PITTS e STOTLAR, 2002, p. 100).

Por fim, a parte promocional, a que se refere às estratégias para estimular a demanda pelo produto junto ao público-alvo, ou seja, mensagens promocionais para informar e estimular os clientes para realizarem a compra do produto. Patrocínio, publicidade, promoções de vendas, merchandising, relações públicas e investimento corporativo são alguns exemplos de formas de promoção dentro do esporte. 


\subsubsection{Marketing Esportivo no Futebol}

O futebol nasceu na Inglaterra, em meados do século XIX, e foi introduzido no Brasil em 1894, por Charles Muller (MOUTINHO, 2008). De início, o esporte era destinado apenas à elite, sendo considerado uma atividade cultural típica da burguesia. Com o passar dos anos a sua prática foi se popularizando e ganhando espaço entre todos, tornando-se o esporte mais popular do mundo (MOUTINHO, 2008). De acordo com Roche (2002), o que vem acontecendo com o futebol nos últimos anos é a transformação deste esporte em um objeto de consumo.

No Brasil, o futebol se firmou como um esporte de massas. Devido à campanha da Copa de 1938, o esporte começou a ficar mais popularizado e ao mesmo tempo começaram a ser desenvolvidos os primeiros estádios, como São Januário, no Rio de Janeiro, e o Pacaembu, na cidade de São Paulo (TRIVELA, 2021).

Segundo Neto (2000), a partir da década de 1980, no entanto, o futebol se consolidou como um negócio. As emissoras de televisão compraram os direitos de transmissão dos eventos esportivos e integrou a essas empresas a publicidade e a gestão de várias ações de marketing (NETO, 2000). A imagem dos clubes começou a atingir outras pessoas com a transmissão dos jogos.

Diversas ações são utilizadas dentro do marketing esportivo pelos times de futebol, seja para aumentar a quantidade de torcedores, fidelizar os que já são adeptos e conseguir mais prestígio (GASPAR, 2012). Algumas dessas são: reformas ou construções de estádios , lançamento de terceiro uniforme, lançamento de filmes e livros, desenvolvimento de memoriais de clubes, construção de lojas oficiais de clube, programas sócio torcedor, investimentos em outros esportes e patrocínios.

Atualmente o futebol mundial chega à sua $21^{\mathrm{a}}$ edição da Copa do Mundo. Dados divulgados em 2021 pela consultoria Deloitte apontam que o mercado do futebol na Europa atinge a marca $\mathrm{R} \$ 112$ bilhões. As cinco grandes ligas europeias - Inglaterra, Itália, Alemanha, Espanha e França - geraram uma receita recorde de 14,7 bilhões de euros em 2018, um aumento de $9 \%$ em comparação ao ano anterior.

Em 2018 no Brasil foram jogadas mais de 19 mil partidas, 29 mil horas de futebol, com uma média de 50 jogos por dia feminino (CBF, 2019). São mais de 7 mil clubes registrados, 
mais de 360 mil atletas, mais de 250 competições realizadas e 798 estádios cadastrados. Dentro desses 360 mil atletas, aproximadamente 347 mil são do gênero masculino enquanto 13 mil do gênero feminino (CBF, 2019). Em contraste, segundo estimativas da PNAD Contínua (Pesquisa Nacional por Amostra de Domicílios Contínua) 2019, a população brasileira é composta por $51,8 \%$ do gênero feminino e $48,2 \%$ do gênero masculino.

Em 2018 a indústria do futebol representou 0,72\% do PIB nacional, representando um valor total de $\mathrm{R} \$ 52,9$ bilhões, sendo $\mathrm{R} \$ 48,8$ bilhões o valor movimentado pelo futebol na economia, R \$ 3,34 bilhões em salários e encargos sociais e R 761 mil em impostos (CBF, 2018).

Os clubes de futebol representam $72 \%$ do total, seguidos pela $\mathrm{CBF}$, com $14 \%$, os Grupos de Mídia, com 7\%. O mercado externo, que é responsável pelas aquisições dos jovens talentos brasileiros, aparece com $2 \%$ de impacto no PIB, enquanto o setor de logística e serviços, investimentos em atletas e infraestrutura, Governo Federal com loterias e arenas, além dos estádios, contribuem com $1 \%$ cada (CBF, 2018).

\subsection{O patrocínio esportivo}

O patrocínio é um investimento na marca esportiva dentro de competições, campeonatos e eventos que apoia as estratégias de marketing utilizadas. Ou seja, é a modalidade de marketing em que uma marca apoia algo ou alguém, geralmente em troca de uma grande visibilidade (PETROCCHI, 2019).

Antigamente o patrocínio tinha como objetivo principal era amparar atividades, normalmente com auxílio financeiro. Atualmente, o conceito está mais amplo e atualizado, onde as empresas compram pacotes de patrocínio com objetivos diversos, olhando os benefícios que a atividade pode trazer para as organizações (MICHAELIS, 2002).

Segundo Javalgi et al. (1994) o patrocínio é a subscrição ou a assinatura de um evento especial para apoiar objetivos da empresa, seja através do aumento da imagem corporativa, do aumento do conhecimento de sua marca ou diretamente estimulando vendas de produtos e serviços. Ele pode ser de duas naturezas, sendo a primeira o patrocínio filantrópico, implicando no suporte a uma causa social ou cultural, e a segunda o patrocínio com natureza comercial visando benefícios mercadológicos. 
Além dessa classificação, o patrocínio pode ser contínuo ou pontual (GWINNER, 1997). O contínuo ocorre quando o evento acontece de uma forma frequente e a empresa segue sendo sua patrocinadora, já o patrocínio pontual ocorre quando a empresa patrocina um evento que acontece uma única vez (D’ASTOUS ET AL., 1995).

Segundo a International Events Group (IEG, 2018), os principais objetivos dos patrocinadores ao realizarem um patrocínio esportivo são: dar visibilidade à marca, elevar lealdade à marca, alterar / reforçar imagem de marca, elevar circulação no ponto-de-venda, estimular vendas e experimentação de produto, demonstrar responsabilidade social, distribuir / exibir / demonstrar produto e fomentar relacionamentos com clientes ou fornecedores.

Para Sandler e Shani (1993), o patrocínio possui vários objetivos, podendo ser divididos em três grupos. O primeiro, os objetivos de mídia, gerando visibilidade e publicidade. $\mathrm{O}$ segundo, objetivos de marketing como o aumento das vendas e novos negócios. Por fim, objetivos organizacionais como a ampliação da imagem corporativa, lembrança da marca, melhora na percepção da marca, envolvimento com seus públicos de interesse e entretenimento.

Sob o ponto de vista de marketing, o patrocínio é um elemento do mix de comunicação que busca conseguir publicidade favorável para a empresa ou suas marcas, dentro de um público-alvo determinado (BENNETT, 1999). A partir dele a empresa pode promover algum suporte a uma pessoa, organização ou um grupo, permitindo-as desenvolver suas atividades e ao mesmo tempo obter benefícios em termos de imagem e conhecimento pelo consumidor daquilo que a empresa oferta no mercado.

Shimp (2001) mostra que um dos aspectos da comunicação de marketing com maior crescimento tem sido o patrocínio. Com a crescente evolução, empresas entendem esta ação estratégica como uma abordagem adequada para melhorar o seu desempenho mercadológico, aumentando a exposição da sua marca e o número de consumidores (SCHARF,2017). Já os clubes, utilizam esse meio como uma importante fonte de receita. $\mathrm{O}$ patrocínio permite a promoção da marca, o aumento das vendas, a ampliação da imagem corporativa e a obtenção de maior visibilidade (CORNWELL et al., 2005; MEENAGHAN, 1991; SANDLER; SHANI, 1993; SANTOMIER, 2008; SHAW; AMIS, 2001).

De acordo com Contursi (2003), o patrocínio pode incluir os direitos de utilização de logotipos, nomes, marcas ou representações gráficas, o direito de exclusividade na associação 
de um produto ou categoria de serviços, o direito de intitular um evento ou instalação esportiva, a vantagem de utilizar várias designações na conexão com um produto ou evento, o direito sobre a utilização de um serviço ou produto, ou o direito do proprietário do produto em deliberar sobre o evento ou produto e o direito de conduzir determinadas ações promocionais.

Segundo relatório apresentado pela IEG, em 2018, os gastos das marcas com esporte aumentaram 4.9\% em relação a 2017 e alcançaram um total de US $\$ 65.8$ bilhões. Por outro lado, ainda no âmbito da comunicação, o orçamento para publicidade aumentou $4.3 \%$ e o investimento em ações de marketing e promoção em $4.1 \%$. Dessa forma, vimos nos últimos tempos um esforço maior em iniciativas envolvendo o patrocínio, enquanto a promoção tem ficado em segundo plano. Foram investidos, em 2018, US\$ 24.2 bilhões na América do Norte (aumento de $4.5 \%$ em relação a 2017), US\$ 17.6 bilhões na Europa, US\$ 16.6 bilhões na Ásia e US\$ 4.6 bilhões na América Latina. Entre os segmentos que mais investiram, destacam-se: seguradoras, montadoras, cervejarias e instituições financeiras.

Segundo dados da Two Circles e IEG (2018), os patrocínios globais sofreram uma grande queda em 2020, reduzindo aproximadamente 37\%, passando de US \$66 bilhões em 2019 para US \$42 bilhões naquele ano por conta da pandemia (SPORTS VALUE, 2021). Os grandes patrocinadores nos últimos anos, como as indústrias financeira, automotiva, de energia e as companhias aéreas foram muitos afetados pela pandemia, reduzindo assim os seus investimentos no patrocínio (MARKETING ESPORTIVO, 2020).

"Com o esporte ao vivo interrompido globalmente desde março, o valor que as propriedades esportivas conseguiram oferecer às marcas parceiras foi limitado. Houve cortes de custos em setores que investem fortemente em patrocínios, apresentando também um desafio significativo na assinatura de novos negócios”, explica Gareth Balch, executivo-chefe da Two Circles (in MARKETING ESPORTIVO, 2020).

Estudo conduzido com a Associação Europeia de Patrocínios (ESA), mostrou importantes tendências para marcas patrocinadoras. A análise dos dados, a inovação tecnológica, a melhora da mensuração do investimento, marketing de conteúdo e criatividade tornam-se essenciais para os patrocínios na atualidade (in SPORTS VALUE, 2021). Segundo a European Sponsorship Association-ESA, os fatores prioritários no pós-pandemia para patrocinadoras na Europa são: análise de dados (73\%), inovação tecnológica (54\%), mensuração do investimento (53\%), marketing de conteúdo (50\%) e criatividade (48\%). Dessa forma, é visível perceber que 
o COVID-19 trouxe mudanças para o mercado de patrocínios. Novos hábitos foram criados mudando a forma como as empresas enxergam as cotas de patrocínio adquiridas (in SPORTS VALUE, 2021).

\subsubsection{O patrocínio no futebol}

O patrocínio no futebol surgiu na Alemanha, em 1973, quando o time Eintracht Braunschweig resolveu colocar a cervejaria Jagermeister em seu uniforme para um projeto de marketing, apesar de ser proibido na época (BELLON, 2020). A partir do sucesso da experiência, e com a liberação da FIFA para os clubes exibirem as marcas de seus patrocinadores nos uniformes de jogo, nos anos 1980, vários outros times começaram a incluir em seus uniformes logomarcas de seus patrocinadores. Um exemplo disso foi o Bayern de Munique, quando passou a exibir a marca Adidas em seu uniforme, sua patrocinadora até os dias atuais (BELLON, 2020).

No Brasil, o primeiro clube a exibir um patrocinador oficialmente em seus uniformes foi o Democratas de Sete Lagoas, em Minas Gerais. Ademais, um dos momentos mais icônicos no futebol nacional foi quando o Vasco da Gama divulgou em seu uniforme a logomarca do Sistema Brasileiro de Televisão (SBT) como forma de afrontar a detentora dos direitos de transmissão da então Copa João Havelange, a Rede Globo de Televisão (BELLON, 2020).

Destaca-se também o sucesso do Fluminense Football Club e a empresa Unimed, o Sport Club Corinthians Paulista e a marca Suvinil, a Sociedade Esportiva Palmeiras e a Parmalat, além do São Paulo Futebol Clube e a coreana LG.

Segundo Afif (2000), no Brasil o futebol é a modalidade que possui os maiores investimentos em patrocínio esportivo. Segundo um estudo realizado por Bennett (2007), mais de $20 \%$ dos torcedores estão dispostos a adquirir produtos da empresa patrocinadora. No futebol, o patrocínio esportivo apresenta-se principalmente através da publicidade e da propaganda nos vestuários, nos estádios, centros de treinamento e nos equipamentos esportivos, além dos jogadores individualmente (ZUNINO, 2006).

Os clubes de futebol são excelentes veículos de comunicação, visto que geram mais tempo de imagem do que se iguais valores fossem pagos para as emissoras na forma de comerciais (BUDOLLA e SOUZA, 2005). Assim, um motivo para o interesse das empresas em ter seu nome vinculado a um time de futebol é a exposição que o esporte possui na mídia. 
Tanto o time de futebol quanto a marca patrocinadora se beneficiam do patrocínio, pois de um lado há ingresso de recursos no time e, de outro, destaca-se a grande visibilidade de marca junto ao público. Esse é uma ferramenta que o marketing disponibiliza às organizações que pretendem utilizar-se de estratégias diferenciadas e capazes de atingir um público específico (FERRARI, 2011).

Ao longo dos anos observam-se épocas marcadas por patrocínios em áreas específicas. A primeira delas pode ser considerada a fase das bebidas não alcoólicas (Coca-Cola) e depois a alimentação (Parmalat). Logo após, vieram os patrocínios da área de construção, imobiliário e acabamento (Suvinil), seguidos de empresas dos setores automobilístico, eletroeletrônico e, então, os bancos. Com a Caixa Econômica Federal fora dos patrocínios, conforme será abordado adiante, os bancos digitais passaram a se destacar (NOVO ESPORTE, 2020).

Segundo José Colagrossi, diretor executivo do IBOPE Repucom (2019), o início de 2019 foi marcado pela saída do maior patrocinador do futebol naquele momento, a Caixa, o que gerou um cenário de enorme preocupação e instabilidade entre os muitos clubes patrocinados pela estatal brasileira. $\mathrm{O}$ vácuo gerado pela saída acabou cedendo espaço para novos entrantes, como os bancos digitais e sites de apostas esportivas. O setor financeiro, que foi o $5^{\circ} \mathrm{em}$ volume de marcas em 2017, passando para $2^{\circ}$ em volume de marcas em 2018, se tornou em 2019 o setor com maior volume de marcas investindo em patrocínio em camisas na Série A do futebol brasileiro. Ainda segundo José Colagrossi, ele aposta que os contratos de patrocínio se caracterizam pela consolidação da combinação "visibilidade-engajamento" como moeda de avaliação de retorno de patrocínio, além de uma tendência das marcas próprias de material esportivo e segmento de apostas (IBOPE REPUCOM, 2019).

A Caixa esteve como patrocinadora master (à frente) de 14 dos 20 clubes que disputaram a série A do campeonato brasileiro de futebol em 2018. Após sua saída, em 2019, os bancos digitais ganharam destaque, ocupando posição em 8 clubes, até o final de 2019. No final daquele ano o setor financeiro dominava esta propriedade (posição de maior destaque). Destaca-se o patrocínio nos uniformes na parte frontal, no centro, abaixo do peito, é a posição de propriedade de maior valor em relação a uniformes de jogos (IBOPE REPUCOM 2019).

Ainda segundo o Relatório IBOPE REPUCOM (2019), os segmentos mais presentes entre os patrocinadores no futebol profissional brasileiro de 2019 foram os setores "Financeiro", "Alimentação" e "Imobiliário, construção e acabamento". O setor "Financeiro" liderou em 
volume de marcas. Foram 23 marcas diferentes que patrocinaram clubes da série A em 2019. O setor "Imobiliário, construção e acabamento" e "Alimentação" empataram em segundo lugar em volume, com 16 marcas diferentes cada uma. O setor de apostas esportivas aparece pela primeira vez neste ano (IBOPE REPUCOM, 2019).

Em 2019, as marcas próprias também ganham destaque. O Campeonato Brasileiro de 2019 apresentou um recorde de clubes que optaram por marcas próprias para fabricação e distribuição de seus materiais esportivos. Segundo Alberto Maia, ex-presidente do Paysandu e atual diretor executivo da MM Manager Sport, tal mudança tem como principal vantagem otimizar a cadeia de produção e distribuição dos produtos. Este tipo de gestão tem sido mais comum em times com concentração regional de torcedores, viabilizando a distribuição e gerando acréscimo de receita graças aos royalties maiores e acréscimo nas vendas, sobretudo pela possibilidade de oferecer um preço final menor aos consumidores (IBOPE REPUCOM, 2019).

No Brasil, alguns casos de patrocínio no futebol masculino mais recente que chamam a atenção são: Flamengo, com o Banco Regional de Brasília (BRB), recebendo R \$ 35 milhões anuais; Corinthians, com a Neo Química, anunciando que receberá $\mathrm{R} \$ 17$ milhões fixos por ano com o acordo e Palmeiras e Crefisa, que renovaram acordo por três temporadas no início de 2019. Anunciado como o "maior patrocínio da América Latina" à época, o contrato prevê pagamento de R \$ 81 milhões anuais pela exclusividade da marca na camisa, bonificações por metas que poderiam chegar a $\mathrm{R} \$ 34$ milhões por ano e outros $\mathrm{R} \$ 6,8$ milhões por "propriedades de marketing" (REDAÇÃO GOAL, 2021).

No exterior, os contratos na modalidade masculina são maiores ainda. O Manchester United tem um patrocínio anual de US \$80 milhões em uma parceria com Chevrolet. Já o Real Madrid fechou um acordo de $€ 110$ milhões com a Adidas até 2030. Além desses, destaca-se a Bet365, firmando um patrocínio com 10 clubes da LaLiga, como Villarreal, RCD Espanyol, Atlético, Real Betis e Getafe (SPORTBUZZ, 2021).

Segundo Gustavo Oliveira, vice-presidente de marketing e comunicação do Flamengo, o COVID-19 fez com que o patrocínio no mundo do futebol mudasse (MURAD, 2020). Ainda segundo ele, antes as empresas buscavam apenas a visibilidade da marca e realizavam patrocínios pontuais. Atualmente elas buscam a aproximação e um engajamento forte com o torcedor (MURAD, 2020). 
Na modalidade feminina, no Brasil, destaca-se primeiramente a marca Guaraná Antártica, quando se tornou, em 2019, o patrocinador oficial do Campeonato Brasileiro Feminino de Futebol. A partir de então, a marca terá direitos de exposição nas placas de publicidade durante as partidas, poderá fazer ativação durante os intervalos dos jogos, além de realizar posts nas redes sociais da competição. A empresa já promoveu algumas campanhas e manifesto de apoio à modalidade, convocando outras marcas a valorizarem o esporte e as jogadoras em suas publicidades. A agência de publicidade Almap BBDO, o Boticário, o DMCard, a GOL, o Itaú e a Lay's foram algumas empresas que aceitaram o convite (BENTES, 2020)

Outra marca que merece destaque é a Nike, patrocinadora oficial da seleção brasileira, onde também têm realizado diversas ações que promovem a inclusão e incentivam as mulheres no esporte. A marca desenvolveu, pela primeira vez na história, uniformes pensados exclusivamente para as mulheres, em 2019 com a inscrição "Mulheres Guerreiras do Brasil” nas costas da gola da camisa. Segundo David Haigh, CEO da Brand Finance, o patrocínio no futebol feminino traz a possibilidade de muitas marcas se exporem a um público de mulheres jovens e ambiciosas que podem ter ficado inacessíveis por meio do futebol masculino (BRAND FINANCE, 2019).

É possível citar também a Riachuelo, empresa varejista de moda, que assinou em 2020 contrato com a CBF, patrocinando o Campeonato Brasileiro Feminino A-1 atpe 2023. Está prevista a exibição da marca nas placas de publicidade colocadas no entorno dos gramados de todos os jogos e nas redes sociais oficiais da competição (PROMOVIEW, 2019).

A empresa Uber também assinou um contrato com a Confederação Brasileira de Futebol (CBF) e a agência de marketing esportivo Sport Promotion até o final de 2019, tornando-se também patrocinadora da competição. "Neste ano, a Copa do Mundo comprovou que o brasileiro é fã do futebol feminino. A chegada da Uber auxiliará ainda mais na popularização do esporte e das nossas atletas no País, com ações para estimular ainda mais a presença do público nos games", diz Alfredo Carvalho Filho, diretor comercial da SportPromotion, a agência que detém os direitos de comercialização da publicidade do Brasileirão (PROMOVIEW, 2019). 


\subsection{O Futebol Feminino}

O futebol feminino vem ganhando espaço no mercado nos últimos anos, tanto em relação à prática quanto ao consumo, como esporte. De acordo com o Ibope (2019), entre 2014 e 2018 houve aumento de $30 \%$ no tempo médio consumido do futebol por mulheres. Somado a isso, houve um salto de $51 \%$ no tempo médio consumido pelos jogos femininos pela população em geral (FERA, 2019).

Um acontecimento que pode explicar esses números foi a Copa do Mundo na França, em 2019, quando aproximadamente 1,12 bilhão de pessoas assistiram ao torneio, significando um aumento de 30\% em relação à edição de 2015. Segundo Bryan Anderson, diretor de avaliação da Brand Finance, a Copa do Mundo quebrou vários recordes em termos de audiência, seguidores on-line e cobertura geral, sendo um catalisador para uma revolução empresarial nos negócios das mulheres (BRAND FINANCE, 2019). Marcas como Visa (patrocinadora oficial), O Boticário, Guaraná Antarctica, Unilever Brasil, Votorantim S.A., Corteva, Athié Wohnrath e Votorantim Cimentos foram as patrocinadoras da competição (SITE GLOBO, 2019).

Dentro dessa competição, vale ressaltar o prêmio obtido pelas campeãs da Copa do Mundo Feminina. Em 2019 elas receberam o dobro do prêmio em dinheiro em comparação com as vencedoras de 2015, com US \$4 milhões em disputa, e o fundo geral de prêmios também dobrou para US \$30 milhões (BRAND FINANCE, 2019). Apesar do avanço, há ainda uma grande discrepância de recursos destinados à esta modalidade quando comparada à Copa do Mundo Masculina, onde os vencedores levaram US\$ 40 milhões, com um prêmio total em dinheiro chegando a US\$ 440 milhões. (BRAND FINANCE, 2019).

Outro marco do ano de 2019 foi o novo regulamento publicado pela CBF, determinando que todas as equipes da primeira divisão do Campeonato Brasileiro Masculino precisam ter um time feminino adulto e, pelo menos, uma categoria de base da modalidade. Tal medida obriga os clubes a investirem no futebol feminino, além de estimularem a formação de jogadoras nas suas categorias de base (CBF, 2020).

Neste mesmo ano observou-se também o aumento no consumo de equipamentos esportivos. Segundo informações divulgadas pela Nike, as vendas das camisetas da seleção feminina dos Estados Unidos, que ficaram com o título da Copa, bateram o recorde histórico de vendas, superando os times masculinos e femininos (TINGA, 2020). 
Outro marco histórico para o futebol feminino internacional foi o contrato de patrocínio da marca britânica Barclays com a Football Association Women's Super League (FA WSL) a partir do início da temporada 2019/20. O contrato de três anos ultrapassa $£ 10$ milhões, o que inclui um prêmio de $£ 500.000$ para os campeões da liga, o primeiro de sua história. A FA descreveu o acordo como "o maior investimento de uma marca no esporte feminino do Reino Unido" (BRAND FINANCE, 2019).

Segundo o relatório anual publicado pela Brand Finance em 2019, o valor potencial total de patrocínio no futebol feminino globalmente é subestimado em mais de US \$ 1,2 bilhão. A análise que modela as diferenças entre as visualizações e prêmios em dinheiro da Copa do Mundo de futebol masculino e feminino, bem como o patrocínio atual dentro do futebol masculino, estima o valor do patrocínio do futebol feminino globalmente em US \$ 1,2 bilhão a mais do que o atual. Segundo o relatório, a prática atual de agrupar patrocínios masculinos e femininos em um pacote é uma das principais causas de perda de receita para detentores de direitos e de perda de marketing para marcas corporativas (BRAND FINANCE, 2019).

A FIFA anunciou que seguirá com o investimento de US\$1 bilhão no futebol feminino, mesmo com a paralisação do esporte mundial por conta da Covid-19 (MKT ESPORTIVO, 2020). Segundo um porta-voz da FIFA, o dinheiro será direcionado para as diversas áreas do futebol, incluindo competições, capacitação, programas de desenvolvimento, governança, liderança, profissionalização e programas técnicos (MKT ESPORTIVO, 2020).

Em 2020, mesmo com a pandemia, o engajamento da modalidade só aumentou, principalmente no quesito audiência. Diversas partidas de futebol tiveram transmissões espalhadas por TV aberta, TV fechada, redes sociais e streaming. No Twitter, por exemplo, a audiência das transmissões do Brasileirão em 2020 mais que triplicou em relação a 2019: foram mais de 5 milhões de pessoas que assistiram aos jogos neste ano, contra 1,5 milhão no ano anterior. Além disso, a final do Campeonato Brasileiro de 2020 foi transmitida por rádio, televisão aberta e internet (RODRIGO ALCÂNTARA, 2020 in SITE BOLA VIP)

Ainda em 2020, um acontecimento importante para dar visibilidade ao futebol feminino foi a apresentação pela Confederação Brasileira de Futebol (CBF) dos cargos de coordenadoras de competições femininas e da seleção brasileira, dados à Aline Pellegrino (ex-jogadora) e Duda Luizelli, respectivamente. Ambas são as primeiras mulheres a comandarem o futebol feminino na CBF. A partir disso, a CBF igualou o pagamento de treinos para homens e 
mulheres, colocou as fases finais do Brasileirão em grandes estádios e anunciou o uniforme próprio da seleção feminina pela primeira vez na história. Além disso, as novas gestoras foram responsáveis por implementar o uso do VAR, o troféu para a "craque da partida", jogos nos grandes estádios, entre outras ações (CBF, 2021).

Em relação aos campeonatos disputados pelas mulheres no Brasil, a principal competição é o Campeonato Brasileiro de Futebol Feminino, disputado desde 2013. Em 2019, a Band adquiriu os direitos de transmissão da CBF e em novembro de 2020, a ESPN Brasil passou a transmitir a competição (CBF, 2021).Segundo dados divulgados pela $\mathrm{CBF}$, além do Brasileirão A-1 e A2, o futebol feminino vai ter o seguinte calendário: Jogos Olímpicos de Tóquio 2020 (adiados para 2021), Campeonato Brasileiro Feminino Sub-18 e 16, Copa Libertadores da América Feminina, Torneio de Desenvolvimento Conmebol Sub-14 e Sub-16 e os vários Campeonatos Estaduais. Destaca-se os times paulistas, Centro Olímpico, Corinthians, Ferroviária, Rio Preto e Santos, campeões em 6 das 7 edições realizadas (CBF, 2021).

Assim, nota-se que o futebol feminino vem ganhando espaço e visibilidade dentro do mercado de futebol, especialmente no Brasil. O aumento do público nos estádios, o aumento nos valores dos prêmios nas competições, as camisas com patrocinadores próprios, os contratos milionários com grandes jogadoras, o aumento no número de jogadoras profissionais e a venda de direitos de transmissão são apenas alguns pontos que retratam o avanço da modalidade no mercado.

Em relação ao patrocínio propriamente dito, ele vem avançando, principalmente nos últimos 3 anos, porém está longe de chegar perto da modalidade masculina. Marta, eleita seis vezes como melhor jogadora do mundo pela FIFA, recebe de salário anual cerca de US\$ 400 mil, contra US\$ 17 milhões de Neymar, vindos de publicidade e patrocínio, segundo dados divulgados pela revista americana Forbes em 2019 (SANTOS, 2019). Segundo David Haigh, CEO da Brand Finance, acordos recentes, incluindo o contrato de sete anos da Visa com a UEFA e o apoio da Lucozade às Lionesses inglesas, esses são passos na direção certa para aproveitar o aumento da popularidade do esporte (BRAND FINANCE, 2019). 


\section{Metodologia de Pesquisa}

\subsection{Introdução}

Como meio de alcançar os objetivos propostos no capítulo 1, foi escolhido o método Delphi, que oferece respostas com base em opiniões consensuais de experts atuantes na área de interesse: esportes, patrocínios e futebol, em especial.

Segundo Hsu e Sandford (2007),

“O método Delphi é amplamente utilizado e aceito como forma de coletar dados de respondentes dentro de seu domínio de especialização. Essa técnica é projetada como um processo de comunicação em grupo que visa alcançar uma convergência de opiniões sobre uma questão específica do mundo real. O processo Delphi tem sido usado em vários campos de estudo, como planejamento de programas, avaliação de necessidades, determinação de políticas e utilização de recursos para desenvolver uma gama completa de alternativas, explorar ou expor suposições subjacentes, bem como correlacionar julgamentos sobre um tópico abrangendo uma ampla gama de variedade de disciplinas (p.1)".

Dessa forma, ele se mostra como um método válido, ao possibilitar que especialistas colaborem através de procedimentos sistemáticos para obter, trocar e desenvolver opiniões informadas sobre um tópico específico (RAYENS; HAHN, 2000; FRANKLIN; HART, 2007; DUNN, 2015). A técnica se baseia no uso estruturado do conhecimento, da experiência e da criatividade de um painel de especialistas, pressupondo que o julgamento coletivo, quando organizado adequadamente, é melhor que a opinião individualizada (TUROFF, 1975).

De acordo com seus precursores, Dalkey e Helmer (1963), o método Delphi tem como objetivo obter o mais confiável consenso de um grupo de especialistas, por meio de uma série de questionários intensos, intercalados por feedbacks controlados de opiniões. Esse consenso pode ser obtido após "rodadas" de envio das respostas de todos os participantes a cada participante, com a possibilidade de manterem ou alterarem seus julgamentos prévios.

Dessa forma, o método tem quatro características fundamentais. A primeira delas é o anonimato dos participantes da pesquisa, a consulta aos especialistas para a coleta de dados, a aplicação de rodadas interativas e com feedback, de forma que os participantes possam rever 
suas opiniões e refletir sobre elas e a busca por consenso (SÁFADI, 2001). A seguir uma ilustração do modelo esquemático do método com a descrição de suas etapas.

Figura 2: Etapas do Método Delphi

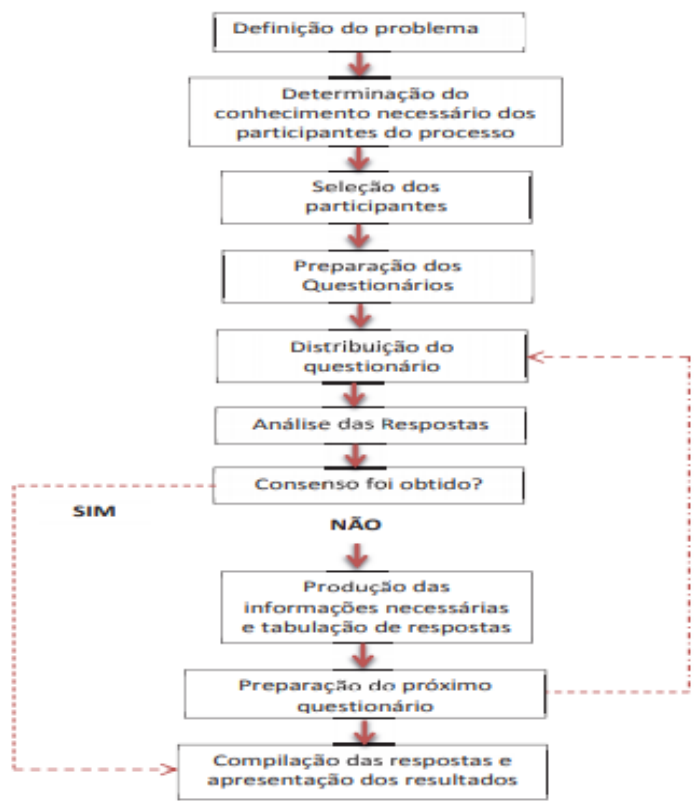

Fonte: OLIVEIRA, J. S. P. COSTA, M. M.; WILLE, M. F.C.; MARCHIORI, P. Z.

Conforme as etapas propostas na Figura 3, o método começa com a definição do problema. Após esta definição são determinados os conhecimentos necessários dos participantes que farão parte do processo, gerando assim uma lista de perfis que serão alvo dos convites para participação os chamados especialistas. Na sequência, preparam-se os questionários, que são distribuídos aos especialistas, tendo em vista obter o seu parecer, com base em sua experiência e conhecimento. O questionário inicial fornece aos participantes um ponto de origem para os seus pensamentos/ suas considerações e possibilita a coleta de dados de forma estruturada (FRANKLIN e HART, 2007). A partir das respostas dos questionários, iniciam-se as análises por parte do pesquisador, buscando encontrar os pontos de vista onde haja consenso em relação ao assunto abordado.

Nesta etapa duas situações podem ocorrer: (i) haver consenso (concordância) entre os especialistas, através da compilação de respostas e apresentação dos resultados do estudo, ou, (ii) divergências entre as respostas dos especialistas. No caso de haver divergências, preparase o próximo questionário com foco nos pontos divergentes $\left(2^{\circ}\right.$ round), e encaminha-se novamente o questionário aos especialistas para que tomem conhecimento dos argumentos 
apresentados pelo grupo de experts e possam, com base nas respostas dos demais, manter, melhor detalhar ou alterar suas considerações. Assim, sucessivamente, busca-se, através de rodadas de questionários a eventual obtenção de consensos em relação aos assuntos tratados.

Franklin e Hart (2007) ressaltam que o objetivo do Delphi não é alcançar necessariamente o consenso ou uma resposta única. A sua função é obter o maior número possível de respostas e opiniões de grande qualidade, de um grupo de especialistas, de modo a subsidiar tomadas de decisão. Eles ressaltam ainda que as características que distingue este método de outras técnicas são: o anonimato, o feedback das contribuições individuais, a construção e a apresentação das respostas do grupo comuns a todos e a possibilidade de revisão e alteração das respostas.

\subsection{Escolha dos sujeitos}

No método Delphi, os participantes são um grupo composto por “especialistas" dentro do tema pesquisado. A definição do quadro de especialistas é vital para a execução do método, de modo a assegurar que todas as opções relacionadas à temática investigada sejam passíveis de serem exploradas (YAU e CHIU, 2015; HUMPHREY-MURTO et al., 2017)

A quantidade de especialistas envolvidos num grupo Delphi tem efeito direto no potencial de ideias a serem consideradas na geração de informações e na quantidade de informações com que o pesquisador pretende trabalhar (HASSON et al., 2000). Todavia, não existe um consenso na academia sobre a quantidade ideal de participantes num grupo Delphi, porque essa quantidade depende do escopo e contexto da pesquisa (VERGARA, 2008) e de fatores extrínsecos ao pesquisador, como, por exemplo, a disponibilidade de especialistas para participar.

Através de contatos pessoais, Instagram e LinkedIn, foi possível encontrar um número considerável de especialistas da área. De forma anônima entre os respondentes participaram da pesquisa os seguintes experts:

- Marinus de Vries- Em 2019 trabalhou na área de patrocínio do Flamengo como Trainee, sendo responsável pelo suporte no atendimento aos principais patrocinadores nacionais e internacionais do clube, captação e negociação de novos patrocínios e estruturação e planejamento de ativações para as marcas patrocinadoras. Recentemente fundou uma agência que conecta marcas patrocinadoras com o esporte, Cinza Ink. 
- Fernando Paz - Atualmente é responsável pela área de patrocínios da Klefer Marketing Esportivo, trabalhando diretamente na Copa do Mundo de 2022. Possui vasta experiência em Estratégia Digital, Gestão de Marketing, Marketing Integrado, Publicidade e Patrocínio.

- Gustavo Machado - Diretor de Marketing na Agita Marketing Criativo. Experiência pautada nas atividades de Gestão de Projetos e Planejamento de Comunicação Integrada, Marketing, Branding, Patrocínio e Marketing Esportivo.

- Thiago Junqueira - Gerente de Patrocínios na DL7 Sports Marketing e na Klefer Marketing Esportivo, trabalhando em conjunto com o Fernando Paz. Thiago está trabalhando diretamente na Copa do Brasil de Futebol.

- Valentina Monteiro - Analista de Comunicação na CBF Academy, tendo já atuado no Comitê Olímpico Esportivo Francês como assistente de comunicação.

- Carol Almirón - Além de coordenadora adjunta e professora da CBF Academy, Carol trabalha há mais de oito anos na FIFA, sendo atualmente responsável por Relações com a Mídia e Operações de Mídia (em coordenação com o Departamento de Mídia da FIFA em Zurique). No seu currículo também já teve uma passagem na Conmebol, atuando diretamente na Libertadores, tendo contato direto com dirigentes e clubes da Conmebol, Federações e seleções.

- Valesca Araújo - Com experiência a mais de 25 anos em organização de eventos esportivos, já trabalhou no COB, FIFA, CBF, estando atualmente na CONMEBOL.

- Erich Beting - Erich já trabalhou na Lance, Bandsports, UOL, TK10 Marketing Esportivo, Sportv e atualmente é o CEO da empresa Máquina do Esporte, totalizando mais de 20 anos de experiência no mundo do esporte.

- Bruno Maia - VP de Marketing no Vasco da Gama e atualmente é o fundador e CEO da Agência 14 (Agência de conteúdo estratégico com foco no esporte).

- Bernardo Pontes - Gerente de Marketing no Fluminense, Diretor de Marketing do Vasco, Comitê Organizador da FIFA em 2014, Diretor de Marketing do Cruzeiro. Atualmente é o gerente de marketing do Flamengo.

- Alessandro Rodrigues - Já foi executivo de futebol feminino no Santos FC nos últimos 3 anos e recentemente constituiu uma empresa chamada Matchday Brasil voltada 100\% ao futebol feminino cuja atuação central é justamente em solucionar a lacuna entre as marcas e os clubes e atletas. 
- Gil Rezende Cruz - Desde 2015 atua no mercado de marketing esportivo, passando por algumas empresas, como: BFV Marketing Esportivo, Botafogo e atualmente é o Cofundador da Go! Marketing Esportivo.

- Cesar Reis - Analista de Performance no Futebol Profissional Masculino. Já foi coordenador do departamento de análise de desempenho do Fluminense, coordenador na área de tecnologia esportiva para o Comitê Olímpico Brasileiro por 8 anos e Coordenador da Olé Brasil Academy.

- Danielle Vilhena - Líder de Projetos na Agência 14, sendo responsável por desenvolver e gerenciar conteúdo de marca, estratégias digitais e produção executiva para importantes marcas e eventos como: COB (Comitê Olímpico Brasileiro) e Time Brasil, Facebook, Globo, Mercado Bitcoin (Vasco da Gama) e outros.

- Manuelle Pires - Profissional de mídia com mais de 6 anos de experiência em Produção de Conteúdo, Marketing Digital, Mídia Social e Desenvolvimento / Crescimento de Produto. Atualmente está trabalhando no Facebook e Instagram atendendo o mercado esportivo brasileiro, sendo a líder da estratégia Mulheres no Esporte na América Latina.

\subsection{Coleta de Dados}

O primeiro contato com os especialistas listados acima se deu através do Instagram, do LinkedIn e do WhatsApp, sondando sobre o interesse e a disponibilidade em participar da pesquisa. Após a confirmação, foi enviado um convite formal por e-mail (Apêndice 1) explicando a cada especialista o objetivo da pesquisa, o passo a passo do processo, datas esperadas e o compartilhamento dos resultados.

Neste trabalho, a primeira etapa para a aplicação do método Delphi incluiu uma fase de natureza qualitativa, a partir de pesquisas bibliográficas e documentais, nas quais foram levantados dados sobre o patrocínio no futebol e, especificamente, da modalidade feminina.

A coleta de dados se deu através do envio de questionários estruturados, com perguntas predeterminadas, com o objetivo de obter respostas dos experts à mesma pergunta e assim realizar comparações. As questões foram de duas naturezas: perguntas abertas e fechadas, as quais os especialistas eram obrigados a responder. As perguntas fechadas facilitam a identificação de consensos de forma mais objetiva sobre alguns pontos pesquisados, enquanto as perguntas abertas fornecem as explicações ou seus argumentos sobre esses mesmos pontos. A vantagem dessa estratégia é que o questionário inicial fornece aos participantes um ponto de 
origem para suas colocações e com a possibilidade de discorrer sobre seus pensamentos, o que possibilita dirigir a coleta de dados de forma estruturada (FRANKLIN e HART, 2007).

O primeiro questionário foi disponibilizado na plataforma online Google Forms. Todos os especialistas receberam o questionário simultaneamente em seus e-mails e tiveram um período de 5 dias estabelecido para responderem as perguntas (Apêndice 2). Este instrumento de coleta (questionário) passou por um processo de pré-teste para verificar o entendimento completo de todas as perguntas. Após a identificação dos pontos a serem melhorados foi finalizada a versão do questionário para esta primeira rodada.

Conforme pode ser visualizado no Apêndice 2, em algumas questões foi solicitado aos especialistas que respondessem utilizando uma escala do tipo "Muito Importante", "Importante", "Indiferente", "Alguma Importância" e "Nada Importante", além de questões com opções onde os especialistas tinham a possibilidade de escolher mais de um item e diversas perguntas abertas, com a finalidade deles apresentarem as suas respectivas opiniões.

A primeira etapa tinha como objetivo respostas a questionamentos levantados na fase anterior - pesquisa bibliográfica - em especial sobre patrocínio e suas opiniões acerca das discrepâncias entre as modalidades masculina e feminina no futebol brasileiro. Fazer com que os especialistas descrevam cada questão é essencial neste estágio, pois vários entrevistados provavelmente poderão mencionar o mesmo problema usando diferentes termos, como observado por Schmidt (1997).

Na segunda rodada do método foi enviado aos especialistas um novo questionário com o sumário dos resultados obtidos na primeira rodada, enfatizando as perguntas, ou explicações, que não obtiveram consenso, além de um breve comparativo entre as respostas (Apêndice 3). Para gerar esta segunda versão do questionário foi utilizada a análise de conteúdo, criando categorias a partir das respostas recebidas, agrupando-as sob a forma de itens de respostas semelhantes, com o propósito de verificar os níveis de convergência e divergência das respostas dos especialistas. As respostas foram analisadas para remoção de duplicidades e a unificação de todas em categorias.

O método de análise de conteúdo constitui-se em um conjunto de técnicas utilizadas na análise de dados qualitativos (MORAES, 1999). É uma técnica de investigação que tem por finalidade a descrição objetiva, sistemática e qualitativa do conteúdo manifesto da comunicação. Durante o método, é necessário classificar os elementos constitutivos de um 
conjunto de diferenciação, onde o pesquisador vai olhar para as suas unidades de registro e transformá-las em categorias. O agrupamento pode ser semântico, sintático, léxico ou expressivo (MORETTI, 2021).

Vale ressaltar que todos esses itens foram apresentados ao grupo de especialistas com o propósito de se posicionarem novamente, tendo a opção de manterem inalteradas suas posições originais (primeira rodada), acrescentarem considerações ou alterarem suas posições. Em suma, os especialistas poderiam modificar suas respostas ou mantê-las, considerando as respostas apresentadas pelos grupos investigados e os argumentos apresentados nos comentários adicionais. Eles tiveram 5 dias para realizarem essa fase. Após o fim dessa fase, novamente foi utilizado o método de análise de conteúdo para gerar os resultados, a fim de verificar se o consenso foi alcançado.

A identificação dos níveis de consenso foi resultado de análises estatísticas simples, por meio de cálculos proporcionais dos tipos de resposta considerando o número total das respostas. O procedimento adotado por outros autores sugere que uma posição com $2 / 3$ do total das respostas, aproximadamente 67\%, já revela um nível de consenso aceitável (OLIVEIRA, 2019).

\subsection{Limitações do estudo}

As limitações do estudo apontam para os pontos fracos aos quais o pesquisador deve se atentar nas diferentes etapas da realização da pesquisa, desde a formulação das questões até a análise dos resultados obtidos, para fins de restrições às conclusões e a geração de novas hipóteses (VERGARA, 2009).

Quanto às limitações do método Delphi, elas estão associadas à importância das perguntas feitas no primeiro questionário, sendo essencial que reflitam os elementos-chave do tema da pesquisa, além da falta de resultados que não sejam o perfil estatístico de opiniões e percepções expressas dos participantes do painel (FRANKLIN e HART, 2007).

O método Delphi, conforme abordado anteriormente, não tem necessariamente o objetivo de alcançar o consenso ou resposta única. A sua função é obter o maior número possível de respostas e opiniões de grande qualidade, de um grupo de especialistas, de modo a contribuir com as tomadas de decisão. Desta forma, a variante aqui utilizada não produz como resultado uma concordância completamente plena. 
Outro ponto a ser considerado é a respeito da maior tendência de desistências ao longo das etapas, por se tratar de um método mais demorado, necessitando mais paciência e tempo por parte dos especialistas participantes. Essa desistência ao longo do processo reduz a representatividade dos sujeitos e, consequentemente, a identificação do consenso nas últimas rodadas sobre pontos em aberto.

\section{Pesquisa de Campo e Análise dos dados}

Neste capítulo serão apresentados os resultados da pesquisa, bem como a análise e a discussão acerca dos dados levantados na etapa de campo, levando em consideração os traçados no capítulo 1. Esta parte do trabalho foi dividida em 2 seções, de acordo com as 2 fases (rodadas) do levantamento de campo, conforme apresentadas no capítulo anterior. Na primeira seção serão apresentadas as respostas dos especialistas a partir do primeiro formulário enviado, analisando as respostas de maneira a realizar grupamentos das respostas/posições/opiniões semelhantes, com o propósito de verificar os níveis de convergência e divergência. Na segunda seção são apresentados os resultados da primeira rodada. Um e-mail foi enviado para cada especialista listando as suas respectivas respostas frente ao resultado geral, sinalizando aquelas questões onde não alcançaram um consenso, assim como os comentários feitos pelo conjunto dos respondentes. O objetivo era que todos ficassem cientes do resultado, tivessem a oportunidade de visualizar todas as justificativas apresentadas pelos outros especialistas e assim terem a possibilidade de manter ou alterar suas respostas, caso desejassem.

\subsection{Primeira rodada}

A primeira rodada do Método de Delphi foi realizada através formulário 1 enviado aos especialistas via Google Forms. O Formulário enviado foi composto de duas seções, sendo a 
primeira chamada de "Perfil do Respondente" e a segunda "Sobre o Futebol Feminino no Brasil".

O convite formal foi enviado para 21 especialistas, após a confirmação de participação via LinkedIn, WhatsApp e Instagram. Desses 21 especialistas, 15 responderam o formulário 1. Os respondentes foram identificados por números.

\subsubsection{Perfil do Respondente}

A primeira seção do questionário tinha como objetivo descrever o perfil dos respondentes. Foram realizadas perguntas curtas. Todas as perguntas tinham a finalidade de identificar quantos anos de atividade profissional o especialista tem relacionado ao esporte (pergunta 1), ao futebol (pergunta 2), ao patrocínio (pergunta 3) e especificamente ao patrocínio no futebol feminino (pergunta 4). O perfil dos respondentes pode ser observado na tabela 1 abaixo, onde os números indicam a quantidade de anos nas respectivas áreas de atuação. Os nomes dos entrevistados foram ocultados, garantindo o anonimato de todas as respostas.

Tabela 1: Perfil do Respondente

\begin{tabular}{|c|c|c|c|c|c|}
\hline Entrevistado & Pergunta 1 & Pergunta 2 & Pergunta 3 & Pergunta 4 & Pergunta 5 \\
\hline ENT 1 & 5 & 5 & 3 & 0 & 0 \\
\hline ENT 2 & 10 & 10 & 5 & 5 & 5 \\
\hline ENT 3 & 33 & 10 & 0 & 0 & 0 \\
\hline ENT 4 & 9 & 9 & 1 & 0,5 & 0 \\
\hline ENT 5 & 10 & 10 & 10 & 2 & 2 \\
\hline ENT 6 & 12 & 12 & 12 & 1 & 1 \\
\hline ENT 7 & 16 & 3 & 3 & 0 & 0 \\
\hline ENT 8 & 15 & 15 & 6 & 0 & 0 \\
\hline ENT 9 & 8 & 8 & 5 & 8 & 3 \\
\hline ENT 10 & 20 & 17 & 4 & 0 & 0 \\
\hline ENT 11 & 4 & 2 & 4 & 2 & 2 \\
\hline ENT 12 & 8 & 8 & 6 & 0 & 0 \\
\hline ENT 13 & 20 & 20 & 2 & 2 & 0 \\
\hline ENT 14 & 1 & 1 & 0 & 0 & 0 \\
\hline ENT 15 & 22 & 22 & 22 & 15 & 15 \\
\hline MÉDIA & $\mathbf{1 3}$ & $\mathbf{1 0}$ & $\mathbf{6}$ & $\mathbf{2}$ & $\mathbf{2}$ \\
\hline
\end{tabular}

Fonte: Elaboração própria. Dados da pesquisa de campo. 


\subsubsection{Sobre o Futebol Feminino no Brasil}

A segunda sessão foi composta por 11 perguntas, sendo algumas de múltipla escolha, caixa de seleção e com texto de resposta longa, com o objetivo de os especialistas expressarem suas opiniões, bem como suas experiências no assunto.

\subsubsection{Retorno das empresas patrocinadoras}

Compreender a expectativa de retorno das empresas ao patrocinarem o futebol é fundamental para entender o que elas estão buscando ao realizarem essa atividade. Assim, foi apresentada uma lista de determinantes aos especialistas, baseada em artigos científicos publicados, para que esses selecionassem aquelas que considerassem relevantes. Através da leitura de artigos destacam-se os autores Meenaghan (1991), Pope e Voges (2000), Cornwell et al. (2005a), Cornwell et al. (2005b), Santomier (2008) e Kim et al. (2015).

De acordo com as respostas, destaca-se o estreitamento de relacionamento com o público, com 100\% das respostas, seguido da busca de associações à imagem da marca (73,3\%), obtenção de visibilidade com exposição da marca $(73,3 \%)$, possibilidade de aumento das vendas $(53,3 \%)$ e o atendimento de desejos pessoais dos executivos $(46,7 \%)$. O estreitamento de relacionamento com outras empresas, diferenciação da concorrência, obtenção de vantagens fiscais ficaram com 13,3\% cada um e por fim, a associação com causas de inclusão e de empoderamento feminino com 6,70\%. Estreitamento de relacionamento com os clubes não foi selecionado por nenhum participante. 
Tabela 2: Tipos de retorno das empresas com patrocínio do futebol feminino

\begin{tabular}{|c|c|c|c|c|c|c|c|c|c|c|}
\hline Entrevistado & $\begin{array}{c}\text { Buscar } \\
\text { associações } \\
\text { à imagem } \\
\text { da marca }\end{array}$ & $\begin{array}{l}\text { Estreitame } \\
\text { nto de } \\
\text { relacionam } \\
\text { ento com } \\
\text { os clubes }\end{array}$ & $\begin{array}{c}\text { Estreitament } \\
\text { o de } \\
\text { relacionamen } \\
\text { to com outras } \\
\text { empresas }\end{array}$ & $\mid \begin{array}{c}\text { Estreitamento } \\
\text { de } \\
\text { relacionament } \\
\text { o com o } \\
\text { público }\end{array}$ & $\begin{array}{c}\text { Obter } \\
\text { visibilidade } \\
\text { com } \\
\text { exposição da } \\
\text { marca }\end{array}$ & $\begin{array}{l}\text { Possibilidad } \\
\text { e de } \\
\text { aumento } \\
\text { nas vendas }\end{array}$ & $\begin{array}{c}\text { Se diferenciar } \\
\mathrm{da} \\
\text { concorrência }\end{array}$ & $\begin{array}{c}\text { Obter } \\
\text { vantagens } \\
\text { fiscais }\end{array}$ & $\begin{array}{c}\text { Atender } \\
\text { desejos } \\
\text { pessoais dos } \\
\text { executivos }\end{array}$ & $\begin{array}{c}\text { Outro: } \\
\text { Associação } \\
\text { com causas de } \\
\text { inclusão e de } \\
\text { empoderament } \\
\text { ofeminino }\end{array}$ \\
\hline ENT 1 & & & & $\mathrm{x}$ & & & & & & $\mathrm{x}$ \\
\hline ENT 2 & $\mathrm{x}$ & & & $\mathrm{x}$ & $\mathrm{x}$ & $\mathrm{x}$ & $\mathrm{x}$ & $\mathrm{x}$ & & \\
\hline ENT 3 & $\mathrm{x}$ & & & $\mathrm{x}$ & $\mathrm{x}$ & $\mathrm{x}$ & & & $\mathrm{x}$ & \\
\hline ENT 4 & $\mathrm{x}$ & & & $\mathrm{X}$ & $\mathrm{X}$ & $\mathrm{x}$ & & & $\mathrm{x}$ & \\
\hline ENT 5 & $\mathrm{x}$ & & & $\mathrm{x}$ & & & & & & \\
\hline ENT 6 & $\mathrm{x}$ & & $\mathrm{X}$ & $\mathrm{X}$ & & & & & $\mathrm{x}$ & \\
\hline ENT 7 & & & & $\mathrm{X}$ & $\mathrm{x}$ & $\mathrm{X}$ & & & & \\
\hline ENT 8 & $\mathrm{x}$ & & $\mathrm{x}$ & $\mathrm{X}$ & $\mathrm{x}$ & & & & $\mathrm{x}$ & \\
\hline ENT 9 & & & & $\mathrm{X}$ & $\mathrm{x}$ & $\mathrm{x}$ & & & $\mathrm{x}$ & \\
\hline ENT 10 & $\mathrm{x}$ & & & $\mathrm{x}$ & $\mathrm{x}$ & & & & $\mathrm{x}$ & \\
\hline ENT 11 & $\mathrm{x}$ & & & $\mathrm{x}$ & & & $\mathrm{x}$ & $\mathrm{x}$ & & \\
\hline ENT 12 & & & & $\mathrm{X}$ & $\mathrm{x}$ & $\mathrm{x}$ & & & $\mathrm{x}$ & \\
\hline ENT 13 & $\mathrm{x}$ & & & $\mathrm{X}$ & $\mathrm{X}$ & & & & & \\
\hline ENT 14 & $\mathrm{x}$ & & & $\mathrm{x}$ & $\mathrm{x}$ & $\mathrm{X}$ & & & & \\
\hline ENT 15 & $\mathrm{x}$ & & & $\mathrm{x}$ & $\mathrm{x}$ & $\mathrm{x}$ & & & & \\
\hline & $73,30 \%$ & $0,00 \%$ & $13,30 \%$ & $100,00 \%$ & $73,30 \%$ & $53,30 \%$ & $13,30 \%$ & $13,30 \%$ & $46,70 \%$ & $6,70 \%$ \\
\hline
\end{tabular}

Fonte: Elaboração própria. Dados da pesquisa de campo

Com esses dados pode-se concluir, com base nos índices que apontam um maior índice de consenso, que as marcas/empresas, ao patrocinarem o futebol feminino, buscam diferentes objetivos: primeiramente, o estreitamento com o público, a associação da imagem de sua marca ao evento ou público-alvo e a obtenção de visibilidade com exposição da marca, todos com nível de concordância acima de $67 \%$. Os outros objetivos foram poucos citados entre os especialistas. Diante dos consensos identificados, a questão foi encerrada e não levada para a segunda rodada.

\subsubsection{Diferença salarial Feminino X Masculino}

Conforme visto no capítulo 2, é clara a discrepância salarial entre os dois maiores ícones do futebol brasileiro, Neymar e Marta. Segundo dados divulgados pela revista americana Forbes, em 2019, Marta, eleita pela FIFA seis vezes como a melhor jogadora de futebol do mundo, recebe de salário anual cerca de US\$400 mil. Neymar, jogador brasileiro com maior projeção internacional, embora não tenha sido eleito pela FIFA ainda como melhor jogador do mundo, recebe US\$17 milhões, vindos apenas de publicidade e patrocínio. Através dessas informações, foi solicitado que os especialistas se posicionassem a cerca desse tópico com a 
finalidade de exporem a suas respectivas opiniões que explicassem essa diferença. Destacamse as seguintes respostas:

"Por conta de um contexto histórico de exclusão das meninas do esporte, hoje temos um passivo relevante. A diferença dos casos específicos tem a ver com a diferença de maturidade entre os dois mercados. A Marta, por sua vez, recebe muito mais que estrelas de esportes sem demanda de atenção. Há uma relação direta entre esses fatos, ainda que a distância do futebol masculino e feminino seja fruto de uma construção machista de um século." ENT 1

"O retorno de visibilidade que cada um entrega. Só no Instagram, o Neymar é 62x maior que a Marta, fora a visibilidade dos torneios que ele disputa ao longo do ano. Acredito que essa seja a diferença. Em outros esportes, temos uma maior importância do feminino em relação ao masculino" ENT 6

"A diferença, a meu ver, é a enorme diferença entre a geração de receita do futebol masculino em relação ao feminino. Com competições centenárias, clubes e fãs fortes, o futebol masculino movimenta mais dinheiro, dando maior retorno financeiro a toda cadeia." ENT 10

"Essa diferença é reflexo de anos em que o futebol feminino foi preterido culturalmente, alijado de políticas públicas e até proibido. O futebol masculino evoluiu como um negócio global, movimentando cifras vultosas e gerando negócios para marcas de grande porte. As mulheres passaram décadas apartadas desse processo, como se o futebol não fosse para elas, e uma das consequências diretas é a capacidade de geração de receita". ENT 15

Para cada resposta obtida de cada especialista, foi realizada uma síntese com base no método da análise de conteúdo, conforme é possível visualizar na tabela 3. A partir disso, agrupamentos foram realizados com o objetivo de facilitar a análise, conforme visto na tabela 4. Machismo, discriminação e preconceito, visibilidade, receita/retornos diferentes entre as modalidades e herança histórica foram aquelas encontradas. 
Tabela 3: Respostas dos Especialistas Diferença Salarial 


\begin{tabular}{|c|c|c|}
\hline & Respostas & $\begin{array}{l}\text { Síntese da resposta com base no método } \\
\text { da análise de conteúdo }\end{array}$ \\
\hline $\begin{array}{c}\text { ENT } \\
1\end{array}$ & $\begin{array}{l}\text { Por conta de um contexto histórico de exclusão das meninas do esporte, hoje temos } \\
\text { um passivo relevante. A diferença dos casos específicos tem a ver com a diferença de } \\
\text { maturidade entre os dois mercados. A Marta, por sua vez, recebe muito mais que } \\
\text { estrelas de esportes sem demanda de atenção. Há uma relação direta entre esses } \\
\text { fatos, ainda que a distância do futebol masculino e feminino seja fruto de uma } \\
\text { construção machista de um século. }\end{array}$ & $\begin{array}{l}\text { Machismo de um lado e consequente } \\
\text { diferença de maturidade entre as duas } \\
\text { modalidades (masculino em maior } \\
\text { evidência, mais popular, por herança } \\
\text { histórica) }\end{array}$ \\
\hline $\begin{array}{c}\text { ENT } \\
2\end{array}$ & $\begin{array}{l}\text { Os meios de comunicação apenas dão visibilidade para o esporte masculino e o que } \\
\text { as marcas querem é visibilidade. }\end{array}$ & $\begin{array}{l}\text { Visibilidade desproporcional dada pelos } \\
\text { meios de comunicação }\end{array}$ \\
\hline $\begin{array}{l}\text { ENT } \\
3\end{array}$ & $\begin{array}{l}\text { A menor visibilidade do futebol feminino, que não atinge o mesmo número de fãs nem } \\
\text { de consumo de produtos. isso decorrente de se ter um produto (torneios, jogadoras, } \\
\text { ações extracampo) menos cuidado por parte de clubes e instituições }\end{array}$ & $\begin{array}{l}\text { Visibilidade desproporcional dada pelos } \\
\text { meios de comunicação; descuido por parte } \\
\text { de clubes e outras instituições correlatas. }\end{array}$ \\
\hline $\begin{array}{c}\text { ENT } \\
4\end{array}$ & O retorno que cada mercado trás pra eles. & $\begin{array}{l}\text { Retorno do mercado que pode estar ligado } \\
\text { a visibilidade (números de fãs) }\end{array}$ \\
\hline $\begin{array}{l}\text { ENT } \\
5\end{array}$ & $\begin{array}{l}\text { Normal. A diferença de alcance e engajamento entre eles é proporcional ao valor que } \\
\text { recebem. }\end{array}$ & Alcance e engajamento (visibilidade) \\
\hline $\begin{array}{c}\text { ENT } \\
6\end{array}$ & $\begin{array}{c}\text { O retorno de visibilidade que cada um entrega. Só no Instagram, o Neymar é 62x } \\
\text { maior que a Marta, fora a visibilidade dos torneios que ele disputa ao longo do ano. } \\
\text { Acredito que essa seja a diferença. Em outros esportes, temos uma maior importância } \\
\text { do feminino em relação ao masculino. }\end{array}$ & $\begin{array}{l}\text { Visibilidade de cada um e a visibilidade dos } \\
\text { torneios dos quais participam. }\end{array}$ \\
\hline $\begin{array}{c}\text { ENT } \\
7\end{array}$ & $\begin{array}{l}\text { A exposição do futebol masculino ainda é mais de } 40 x \text { superior ao feminino. Isso está } \\
\text { caindo vertiginosamente. }\end{array}$ & $\begin{array}{l}\text { Visibilidade das modalidades (masculino e } \\
\text { feminino) é desproporcional }\end{array}$ \\
\hline $\begin{array}{l}\text { ENT } \\
8\end{array}$ & Visibilidade e retorno financeiro & $\begin{array}{l}\text { Visibilidade e retorno financeiro. (Dois } \\
\text { fenômenos que caminham juntos) }\end{array}$ \\
\hline $\begin{array}{l}\text { ENT } \\
9\end{array}$ & $\begin{array}{l}\text { Embora se trate da mesma modalidade - futebol - São mercados muito diferentes. O } \\
\text { futebol feminino ainda não conta com receitas tradicionais no masculino, tais como } \\
\text { receitas com transmissão e direitos econômicos de atletas. } \\
\text { Assim a comparação nesse momento ainda não faz sentido }\end{array}$ & $\begin{array}{l}\text { Receitas diferentes por decorrência de } \\
\text { visibilidade desproporcional às duas } \\
\text { modalidades (masculino e fem). }\end{array}$ \\
\hline $\begin{array}{c}\text { ENT } \\
10\end{array}$ & $\begin{array}{c}\text { A diferença, a meu ver, é a enorme diferença entre a geração de receita do futebol } \\
\text { masculino em relação ao feminino. Com competições centenárias, clubes e fãs fortes, } \\
\text { o futebol masculino movimenta mais dinheiro, dando maior retorno financeiro a toda } \\
\text { cadeia. }\end{array}$ & $\begin{array}{l}\text { Receitas diferentes por decorrência da } \\
\text { história, diferença da tradição das } \\
\text { competições e consequente número de } \\
\text { torcedores. }\end{array}$ \\
\hline $\begin{array}{c}\text { ENT } \\
11\end{array}$ & $\begin{array}{l}\text { O mercado de patrocínios no futebol brasileiro, e mundial, é muito mais ligado a um } \\
\text { mercado de mídia do que de experiências. Essas remunerações só são possíveis } \\
\text { devido ao grande número de views associados a esses contratos. Infelizmente o meio } \\
\text { do futebol, assim como a sociedade e os executivos “boleiros" são extremamente } \\
\text { machistas e se recusam a enxergar o futebol feminino como uma oportunidade enorme } \\
\text { de ampliação de mercado. Com isso esse problema acaba se tornando perpétuo. O } \\
\text { ambiente do futebol é negacionista, conservador e atrasado em relação a todos os } \\
\text { outros setores do entretenimento. }\end{array}$ & $\begin{array}{l}\text { Menor visibilidade, e consequente renda, } \\
\text { como consequência de preconceito } \\
\text { (machismo) e herança histórica deste tipo } \\
\text { de postura. Setor conservador. }\end{array}$ \\
\hline $\begin{array}{c}\text { ENT } \\
12\end{array}$ & $\begin{array}{l}\text { Visibilidade da modalidade é infinitamente menor que o futebol masculino, por } \\
\text { questões estruturais de federação, de falta de incentivo à prática e desenvolvimento da } \\
\text { modalidade, muito por conta de problemas culturais históricos (machismo). }\end{array}$ & $\begin{array}{l}\text { Visibilidade, consequência de preconceito } \\
\text { (machismo), diferenças estruturais, de } \\
\text { incentivo, herança histórica. }\end{array}$ \\
\hline $\begin{array}{c}\text { ENT } \\
13\end{array}$ & Pouca visibilidade do esporte feminino e discriminação & Visibilidade e preconceito \\
\hline $\begin{array}{l}\text { ENT } \\
14\end{array}$ & $\begin{array}{l}\text { O Futebol Feminino, por ter menos visibilidade, também recebe menos investimento e, } \\
\text { consequentemente, lucra e paga menos do que o masculino }\end{array}$ & $\begin{array}{l}\text { Visibilidade como consequência de } \\
\text { menores investimentos e resultando em } \\
\text { menor receita. }\end{array}$ \\
\hline $\begin{array}{c}\text { ENT } \\
15\end{array}$ & $\begin{array}{l}\text { Essa diferença é reflexo de anos em que o futebol feminino foi preterido culturalmente, } \\
\text { alijado de políticas públicas e até proibido. O futebol masculino evoluiu como um } \\
\text { negócio global, movimentando cifras vultosas e gerando negócios para marcas de } \\
\text { grande porte. As mulheres passaram décadas apartadas desse processo, como se o } \\
\text { futebol não fosse para elas, e uma das consequências diretas é a capacidade de } \\
\text { geração de receita. }\end{array}$ & $\begin{array}{l}\text { Preconceito ao longo da história, } \\
\text { consequências nas receitas diferentes. }\end{array}$ \\
\hline
\end{tabular}


Fonte: Elaboração própria. Dados da pesquisa de campo

Tabela 4: Resultado Diferença Salarial

\begin{tabular}{|c|c|c|c|c|}
\hline & $\begin{array}{c}\text { Preconceito - } \\
\text { machismo }\end{array}$ & Visibilidade & $\begin{array}{l}\text { Retorno do } \\
\text { mercado/receitas } \\
\text { diferentes }\end{array}$ & $\begin{array}{l}\text { Herança } \\
\text { histórica }\end{array}$ \\
\hline ENT 1 & 1 & & & 1 \\
\hline ENT 2 & & 1 & & \\
\hline ENT 3 & & 1 & & \\
\hline ENT 4 & & & 1 & \\
\hline ENT 5 & & 1 & & \\
\hline ENT 6 & & 1 & & \\
\hline ENT 7 & & 1 & & \\
\hline ENT 8 & & 1 & 1 & \\
\hline ENT 9 & & 1 & 1 & \\
\hline ENT 10 & & & 1 & 1 \\
\hline ENT 11 & 1 & 1 & 1 & 1 \\
\hline ENT 12 & 1 & 1 & & 1 \\
\hline ENT 13 & 1 & 1 & & \\
\hline ENT 14 & & 1 & 1 & \\
\hline ENT 15 & 1 & & 1 & 1 \\
\hline & 5 & 11 & 7 & 5 \\
\hline & $33 \%$ & $73 \%$ & $47 \%$ & $33 \%$ \\
\hline
\end{tabular}

Fonte: Elaboração própria. Dados da pesquisa de campo

Diante desses resultados pode-se observar diferentes argumentos para explicar a diferença salarial entre as categorias femininas e masculinas no futebol, mais especificamente de dois ícones brasileiros: Marta e Neymar. Essa questão foi levada para a segunda rodada a fim de encontrar eventualmente um maior consenso nas justificativas.

\subsubsection{Papel da imprensa e dos veículos de comunicação}

A fim de verificar o papel e a importância da imprensa e dos veículos de comunicação na divulgação do esporte, especificamente na modalidade feminina, foram realizadas três perguntas aos especialistas. A primeira tinha a finalidade de comparar o papel da Imprensa em geral na cobertura da categoria feminina em relação à masculina segundo a avaliação dos especialistas: $60 \%$ classificaram como "Ruim", 27\% como "Regular", 13\% como "Péssima" e nenhum voto para "Excelente" e "Boa", conforme visto na tabela 5. 
Tabela 5: Avaliação da cobertura da imprensa e veículos de comunicação em geral da modalidade feminina comparado à modalidade masculina.

\begin{tabular}{|c|c|c|c|c|c|}
\hline Nome & Excelente & Boa & Regular & Ruim & Péssima \\
\hline ENT 1 & & & $\mathrm{X}$ & & \\
\hline ENT 2 & & & & & $\mathrm{X}$ \\
\hline ENT 3 & & & & $\mathrm{X}$ & \\
\hline ENT 4 & & & & $\mathrm{X}$ & \\
\hline ENT 5 & & & $\mathrm{X}$ & & \\
\hline ENT 6 & & & & $\mathrm{X}$ & \\
\hline ENT 7 & & & $\mathrm{X}$ & & \\
\hline ENT 8 & & & & $\mathrm{X}$ & \\
\hline ENT 9 & & & & $\mathrm{X}$ & \\
\hline ENT 10 & & & & $\mathrm{X}$ & \\
\hline ENT 11 & & & & $\mathrm{X}$ & \\
\hline ENT 12 & & & $\mathrm{X}$ & & \\
\hline ENT 13 & & & & & $\mathrm{X}$ \\
\hline ENT 14 & & & & $\mathrm{X}$ & \\
\hline ENT 15 & & & & $\mathrm{X}$ & \\
\hline
\end{tabular}

Fonte: elaboração própria. Dados da pesquisa de campo.

A segunda pergunta estava relacionada ao nível de importância da exposição nas mídias (imprensa e veículos de comunicação) do futebol feminino nos processos decisórios de patrocinarem o futebol feminino. Ela tinha a finalidade de averiguar o peso que as mídias têm no processo de escolha das empresas. $67 \%$ dos respondentes apontaram como "Muito Importante" e 33\% como "Importante", confirmando a hipótese da relevância dos meios de comunicação no processo decisório do patrocínio (Tabela 6). 
Tabela 6: Nível de Importância das mídias para o desenvolvimento da modalidade

\begin{tabular}{|c|c|c|l|l|l|}
\hline Nome & $\begin{array}{c}\text { Muito } \\
\text { Importante }\end{array}$ & Importante & Indiferente & $\begin{array}{c}\text { Alguma } \\
\text { Importância }\end{array}$ & $\begin{array}{c}\text { Nada } \\
\text { Importante }\end{array}$ \\
\hline ENT 1 & $\mathrm{X}$ & & & & \\
\hline ENT 2 & $\mathrm{X}$ & & & & \\
\hline ENT 3 & $\mathrm{X}$ & & & & \\
\hline ENT 4 & & $\mathrm{X}$ & & & \\
\hline ENT 5 & & $\mathrm{X}$ & & & \\
\hline ENT 6 & & $\mathrm{X}$ & & & \\
\hline ENT 7 & $\mathrm{X}$ & & & & \\
\hline ENT 8 & $\mathrm{X}$ & & & & \\
\hline ENT 9 & $\mathrm{X}$ & & & & \\
\hline ENT 10 & & $\mathrm{X}$ & & & \\
\hline ENT 11 & $\mathrm{X}$ & & & & \\
\hline ENT 12 & $\mathrm{X}$ & & & & \\
\hline ENT 13 & & $\mathrm{X}$ & & & \\
\hline ENT 14 & $\mathrm{X}$ & & & & \\
\hline ENT 15 & $\mathrm{X}$ & & & & \\
\hline
\end{tabular}

Fonte: Elaboração própria. Dados da pesquisa de campo. (2021)

A terceira e última pergunta da categoria está relacionada à evolução do nível de atuação da imprensa e dos veículos de comunicação na cobertura do futebol feminino brasileiro atualmente em comparação a 10 anos atrás. 53,3\% apontaram que "Aumentou Muito", 40\% como “Aumentou Pouco" e 6,7\% "Não Houve alteração significativa” (Tabela 7). 
Tabela 7: Evolução das mídias nos últimos anos

\begin{tabular}{|c|c|c|c|c|c|}
\hline Nome & $\begin{array}{c}\text { Aumentou } \\
\text { Muito }\end{array}$ & $\begin{array}{c}\text { Aumentou } \\
\text { pouco }\end{array}$ & $\begin{array}{c}\text { Não houve } \\
\text { alteração } \\
\text { significativa }\end{array}$ & $\begin{array}{c}\text { Diminuiu } \\
\text { um pouco }\end{array}$ & $\begin{array}{c}\text { Diminuiu } \\
\text { muito }\end{array}$ \\
\hline ENT 1 & $\mathrm{X}$ & & & & \\
\hline ENT 2 & & $\mathrm{X}$ & & & \\
\hline ENT 3 & $\mathrm{X}$ & & & & \\
\hline ENT 4 & $\mathrm{X}$ & & & & \\
\hline ENT 5 & & $\mathrm{X}$ & & & \\
\hline ENT 6 & & $\mathrm{X}$ & & & \\
\hline ENT 7 & $\mathrm{X}$ & & & & \\
\hline ENT 8 & & $\mathrm{X}$ & & & \\
\hline ENT 9 & & $\mathrm{X}$ & & & \\
\hline ENT 10 & $\mathrm{X}$ & & & & \\
\hline ENT 11 & & $\mathrm{X}$ & & & \\
\hline ENT 12 & $\mathrm{X}$ & & & & \\
\hline ENT 13 & \multicolumn{7}{|c|}{$\mathrm{X} \%$} & $\mathrm{X}$ & & & \\
\hline ENT 14 & $\mathrm{X}$ & & & & \\
\hline ENT 15 & $\mathrm{X}$ & & & & \\
\hline
\end{tabular}

Fonte: Elaboração própria. Dados da pesquisa de campo

Juntando as três perguntas é visível que avanços na modalidade feminina no futebol brasileiro estão acontecendo. A maior parte dos especialistas apontaram que as mídias têm um peso grande no processo decisório das empresas patrocinadoras e que as suas atuações vêm aumentando nos últimos 10 anos. Devido ao consenso alcançado, essas questões não foram levadas para a segunda rodada.

\subsubsection{Subvalorização dos patrocínios na modalidade feminina}

Uma informação importante acerca do patrocínio no futebol feminina é a subvalorização de seus patrocínios avaliada em aproximadamente US \$1.2 bilhão, segundo o relatório anual publicado pela Brand Finance de 2019. A fim de entender melhor o que explica isso, foi solicitado aos especialistas se posicionarem sobre o assunto.

“Mesma lógica da resposta anterior. Falando apenas no Brasil, temos que ofutebol masculino é um mercado de mais de 120 anos. O feminino, fruto inclusive de 
proibição por decreto federal, é um mercado muito mais novo e de visibilidade infinitamente menor até o momento" (ENT 9).

"Visibilidade da modalidade é infinitamente menor que o futebol masculino, por questões estruturais de federação, de falta de incentivo à prática e desenvolvimento da modalidade, muito por conta de problemas culturais históricos (machismo)"'(ENT 12).

"Visibilidade e falta de interesse do público" (ENT 8).

"Por conta de um contexto histórico de exclusão das meninas do esporte, hoje temos um passivo relevante. A diferença dos casos específicos tem a ver com a diferença de maturidade entre os dois mercados. A Marta, por sua vez, recebe muito mais que estrelas de esportes sem demanda de atenção. Há uma relação direta entre esses fatos, ainda que a distância do futebol masculino e feminino seja fruto de uma construção machista de um século” (ENT 1).

Embora semelhante em natureza à pergunta da diferença salarial, esta questão tinha como foco a discrepância de valor percebido entre as duas modalidades de futebol: masculino e feminino. As explicações apresentadas por cada participante estão expostas na tabela 8, sintetizadas com base no método da análise do conteúdo.

Surge neste conjunto de respostas argumentos de que a diferença de valor percebido por patrocinadores, além da já comentada falta de visibilidade, se deve, em parte, à não atratividade do futebol feminino junto ao público em geral, embora na última Copa do Mundo a equipe feminina tenha gerado grande admiração e envolvimento junto ao público em geral. Se deve, ainda à discriminação, restrições estruturais da modalidade e o fato do mercado ser recente. Na tabela 9 é possível visualizar os agrupamentos realizados, bem como o resumo da questão.

Tabela 8: Respostas dos Especialistas sobre a Subvalorização dos Patrocínios na Modalidade Feminina de Futebol 
Acredito que a mesma resposta anterior serve aqui. O futebol é um produto como outro qualquer. O feminino vem de uma construção recente que acompanha mudanças

fundamentais da sociedade. A capacidade de captar interesse ainda é infinitamente menor. Marcas investem para serem percebidas e se o produto ainda tem um interesse social menor, isso afeta os valores que o produto movimenta. A tendência é que melhores nos próximos anos, mas dificilmente chegará aos níveis do masculino, se tomarmos o que acontece em outros esportes mais iguais como referência. O vôlei masculino, o basquete masculino, o tênis masculino acabam tendo mais audiência. $E$ isso é fruto de uma construção social que vai além do futebol. A sociedade mudando, as distâncias vão mudar.
Construção social da sociedade, com preconceito estrutural. Marcas investem para serem percebidas e a capacidade de captar atenção do futebol é muito inferior ao masculino.

\section{ENT 2 A explicação é a mesma da pergunta subjetiva anterior: os meios de comunicação apenas dão visibilidade para o esporte masculino}

ENT 3 O futebol masculino já está sistematizado em todos os países do mundo, já há a cultura secular da prática e do consumo de futebol. É um mercado consolidado e estruturado há muito tempo, com inúmeras posições profissionais para fazê-lo rodar. O Futebol feminino está em período de implantação e evolução ainda.
Visibilidade prejudicada pela predileção ao masculino

O futebol masculino é estruturado e o feminino em período de implantação e evolução ainda.

\section{ENT 4 O mercado e o que o futebol feminino trás para os seus patrocinadores.}

ENT 5 Visibilidade. O futebol feminino ainda não se tornou uma modalidade atrativa para os fãs, patrocinadores etc.

\section{ENT 6 Exposição das competições e interesse do público em geral. \\ ENT 7 Que o mercado e a estrutura de futebol feminino ainda têm muito a crescer e se aprimorar. \\ Tanto os clubes como a imprensa. Uma sugestão difícil de executar seria parar de se comparar com o masculino e seguir o seu caminho, claro, aprendendo com os erros do masculino para não os repetir, mas enfrentando os desafios de outras formas. Exemplo: se os times de futebol feminino fossem franquias ou time empresa. \\ O futebol masculino que teria que copiar o feminino e não ao contrário.}

ENT 8 Visibilidade e falta de interesse do público

ENT 9 Mesma lógica da resposta anterior. Falando apenas em Brasil, temos que o futebol masculino é um mercado de mais de 120 anos. O feminino, fruto inclusive de proibição por decreto federal, é um mercado muito mais novo e de visibilidade infinitamente menor até o momento

ENT 10 Falta de maior exposição na mídia do futebol feminino como um esporte, não apenas como uma modalidade em expansão. O jogo precisa ganhar mais protagonismo na cobertura, trazendo o debate para o dia a dia tal qual acontece no futebol masculino.

$$
\begin{array}{|l}
\hline E \\
\hline E \\
\hline E \\
\hline E
\end{array}
$$

\section{Machismo estrutural.}

ENT 12 Visibilidade da modalidade é infinitamente menor que o futebol masculino, por questões estruturais de federação, de falta de incentivo à prática e desenvolvimento da modalidade, muito por conta de problemas culturais históricos (machismo).
Menor visibilidade face o menor interesse do público

Visibilidade. Mercado mais novo (já foi proibido legalmente); herança histórica
Visibilidade, por falta de atratividade proporcionada ao público em gera

Exposição/visibilidade e menor interesse do público

Estrutura e mercado do futebol feminino (clubes e imprensa)

\begin{tabular}{c|c} 
Discriminação \\
\hline NT 13 14 & Um número menor de marcas se preocupa em patrocinar o futebol feminino em \\
comparação com o masculino pois este primeiro traz um retorno financeiro menor pela \\
exposiça da marca. A dimensão menos expressiva da modalidade também contribui para \\
que esta seja nichada.
\end{tabular}

ENT 15 Assim como na resposta anterior, é um reflexo de anos em que o futebol feminino foi preterido e as mulheres como consumidoras foram ignoradas.

\section{Visibilidade}

Construção social da sociedade; preconceito/machismo

Restrições de sua visibilidade por questões estruturais e

preconceito/machismo; herança histórica social da sociedade.

Discriminação
$\begin{aligned} & \text { Menor retorno financeiro face sua menor } \\ & \text { visibilidade }\end{aligned}$

Preconceito/machismo; herança histórica

Fonte: Autoria própria. Dados da pesquisa de campo. 
Tabela 9: Resultado Subvalorização dos Patrocínios

\begin{tabular}{|c|c|c|c|c|c|}
\hline & $\begin{array}{l}\text { Discriminação, } \\
\text { machismo }\end{array}$ & $\begin{array}{c}\text { Menor } \\
\text { exposição/ } \\
\text { visibilidad } \\
\text { e }\end{array}$ & $\begin{array}{c}\text { Menor } \\
\text { interesse } \\
\text { do público }\end{array}$ & $\begin{array}{l}\text { Mercado } \\
\text { recente, } \\
\text { herança } \\
\text { histórica }\end{array}$ & $\begin{array}{l}\text { Restrições } \\
\text { estruturais }\end{array}$ \\
\hline ENT 1 & 1 & 1 & 1 & & \\
\hline ENT 2 & 1 & 1 & & & \\
\hline ENT 3 & & & & 1 & 1 \\
\hline \multicolumn{6}{|l|}{ ENT 4} \\
\hline ENT 5 & & 1 & 1 & & \\
\hline ENT 6 & & 1 & 1 & & \\
\hline ENT 7 & & & & 1 & 1 \\
\hline ENT 8 & & 1 & 1 & & \\
\hline ENT 9 & & 1 & & 1 & \\
\hline ENT 10 & & 1 & & & \\
\hline ENT 11 & 1 & & & & \\
\hline ENT 12 & 1 & 1 & & 1 & 1 \\
\hline ENT 13 & 1 & & & & \\
\hline ENT 14 & & 1 & & & \\
\hline \multirow[t]{3}{*}{ ENT 15} & 1 & & & 1 & \\
\hline & 6 & 9 & 4 & 5 & 3 \\
\hline & $40 \%$ & $60 \%$ & $27 \%$ & $33 \%$ & $20 \%$ \\
\hline
\end{tabular}

Fonte: Elaboração própria (2021)

De acordo com a síntese das respostas obtidas, diferentes justificativas foram apresentadas. Dessa forma ela foi para a segunda rodada, a fim de verificar se os participantes concordavam com o resultado e se tinham algo mais a comentar, visando encontrar um eventual consenso nas justificativas.

\subsubsection{Ações de patrocínio por parte da iniciativa privada}

Com o objetivo de entender a posição dos especialistas a respeito das ações praticadas por algumas marcas para incentivar o crescimento do patrocínio no futebol feminino, foi realizada uma pergunta direcionada especificamente a uma ação realizada pela marca Guaraná Antártica muito visível no mercado em 2020. A marca lançou uma campanha incentivando o futebol feminino, provocando as demais marcas a fazerem o mesmo. A Cia Antártica prometeu dividir/substituir a exposição de sua marca nas placas de publicidade nas laterais dos gramados por frases de apoio/incentivo ao futebol feminino. Dentre as respostas, destacam-se: 
"Sim, com certeza! Essa campanha, assim como aquela que colocava logo de outras empresas patrocinadoras do futebol feminino nas latas de guaraná, foram uma clara resposta a copa do mundo feminina de 2019, que para muitos foi um grande divisor de água (principalmente na Europa). O setor privado cada vez mais busca ser regenerativo, ou seja, trazer para si causas sociais importantes e a partir de suas ações transformar a sociedade. Patrocinar algo desde os primórdios da civilização humana significa suportar uma causa (ou artista) que você concorde. Acho que o caminho vem por aí, pq se depender dos órgãos como FIFA e CBF estamos fadados a não ter solução alguma"(ENT 11).

"Foi uma ação que surgiu em meio a necessidade de sensibilização, e foi muito positiva. Porém esse trabalho necessita ser feito pelas instituições responsáveis pelo Fut fem, de forma a massificar o entendimento e a oportunidade que é a modalidade. A falta de ações institucionais levou um patrocinador a ter uma ação mais assertiva e positiva que os responsáveis de fato” (ENT 3).

"Foi uma ação/atitude fantástica. A exposição da marca patrocinadora seria potencializada por essa parceria. Uma pena que a pandemia acabou ocultando essa ação" (ENT 7).

"Sim, mas não é suficiente. O produto precisa melhorar se não o ciclo de patrocínio será curto" (ENT 5).

Esta pergunta recorreu a um exemplo de uma iniciativa individual, uma empresa/marca privada, como incentivadora a outras marcas para participarem como patrocinadoras do futebol feminino. As explicações apresentadas por cada participante estão expostas na tabela 10, sintetizadas com base no método da análise do conteúdo. Surge neste conjunto de respostas um consenso em relação aos méritos de tal ação, onde todos os participantes concordam que é uma excelente iniciativa. Sendo a marca líder de mercado, ao convidar outras marcas a se engajarem num propósito, geram uma influência objetiva forte, onde as marcas, juntas, conseguem mudar o cenário atual.

Tabela 10: Respostas dos Especialistas em Relação à Ações da Iniciativa Privada (Guaraná Antárctica) 


\begin{tabular}{|c|c|c|}
\hline & Respostas & $\begin{array}{l}\text { Síntese da resposta com base no método } \\
\text { da análise de conteúdo }\end{array}$ \\
\hline ENT 1 & $\begin{array}{l}\text { Excelente iniciativa, pois, sendo líder de mercado, ao convidar outras marcas a se } \\
\text { engajarem num propósito, geram uma influência objetiva forte. }\end{array}$ & $\begin{array}{l}\text { Marca líder de mercado gerando } \\
\text { influência. }\end{array}$ \\
\hline ENT 2 & Sim. As marcas precisam de apoio para juntas conseguirem mudar o cenário & $\begin{array}{l}\text { Marcas necessitam de apoio para } \\
\text { mudarem o cenário }\end{array}$ \\
\hline ENT 3 & $\begin{array}{l}\text { Foi uma ação que surgiu em meio a necessidade de sensibilização, e foi muito positiva. } \\
\text { Porém esse trabalho necessita ser feito pelas instituições responsáveis pelo Fut. fem, de } \\
\text { forma a massificar o entendimento e a oportunidade que é a modalidade. A falta de } \\
\text { ações institucionais levou um patrocinador a ter uma ação mais assertiva e positiva que } \\
\text { os responsáveis de fato. }\end{array}$ & $\begin{array}{l}\text { Ação reflete ação de sensibilização por } \\
\text { necessidade. Este trabalho deve ser feito } \\
\text { por instituições responsáveis pelo futebol. }\end{array}$ \\
\hline ENT 4 & Acredito que todo e qualquer esforço é válido para o crescimento da modalidade. & $\begin{array}{l}\text { Todo esforço é válido para o crescimento } \\
\text { da modalidade }\end{array}$ \\
\hline ENT 5 & $\begin{array}{c}\text { Sim, mas não é suficiente. O produto precisa melhorar se não o ciclo de patrocínio será } \\
\text { curto. }\end{array}$ & $\begin{array}{l}\text { O "produto" (futebol feminino) precisa } \\
\text { melhorar (para ter sustentabilidade). }\end{array}$ \\
\hline ENT 6 & $\begin{array}{l}\text { Acho que é uma ação interessante, mas precisa ser mais aprofundada e ganhar mais } \\
\text { força entre outras marcas. Não tem que ser um tiro curto. }\end{array}$ & $\begin{array}{l}\text { Ação interessante, mas requer ações de } \\
\text { outras marcas }\end{array}$ \\
\hline ENT 7 & $\begin{array}{l}\text { Foi uma ação/atitude fantástica. A exposição da marca patrocinadora seria potencializada } \\
\text { por essa parceria. Uma pena que a pandemia acabou ocultando essa ação. }\end{array}$ & $\begin{array}{l}\text { Ação positiva que traz exposição às } \\
\text { marcas envolvidas }\end{array}$ \\
\hline ENT 8 & $\begin{array}{l}\text { É um dos fatores, mas falta engajamento do público e principalmente um bom espetáculo } \\
\text { para assistir, a maioria dos jogos são fraquíssimos }\end{array}$ & $\begin{array}{c}\text { Falta engajamento do público; falta o bom } \\
\text { espetáculo; jogos fraquíssimos }\end{array}$ \\
\hline ENT 9 & 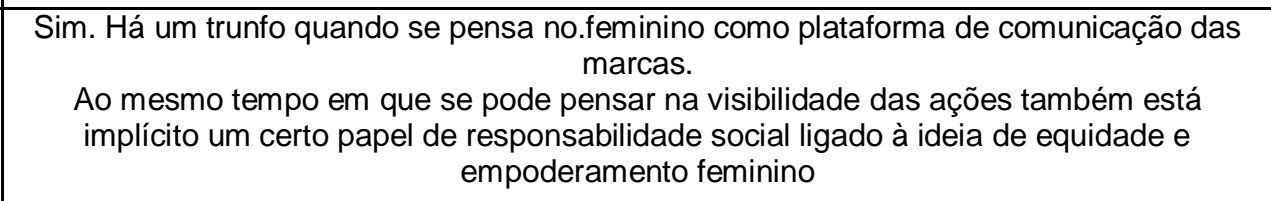 & $\begin{array}{c}\text { Oportunidade da modalidade expor } \\
\text { marcas para o mercado feminino; } \\
\text { possibilidade de promover equidade dos } \\
\text { gêneros }\end{array}$ \\
\hline ENT 10 & $\begin{array}{c}\text { Acredito que possa ajudar no curto prazo, mas não tem sustentabilidade nos médio e } \\
\text { longo prazos se a iniciativa continuar a ser promovida por uma marca, não pelos clubes e } \\
\text { entidades organizadoras das competições. }\end{array}$ & $\begin{array}{l}\text { Insustentável no médio ou longo prazos. } \\
\text { Requer ações de clubes e organizadores } \\
\text { das competições. }\end{array}$ \\
\hline ENT 11 & $\begin{array}{c}\text { Sim, ctz! Essa campanha, assim como aquela que colocava logo de outras empresas } \\
\text { patrocinadoras do futebol feminino nas latas de guaraná, foram uma clara resposta a } \\
\text { copa do mundo feminina de } 2019 \text {, que para muitos foi um grande divisor de água. O setor } \\
\text { privado cada vez mais busca ser regenerativo, ou seja, trazer para si causas sociais } \\
\text { importantes e a partir de suas ações transformar a sociedade. Patrocinar algo desde os } \\
\text { primórdios da civilização humana significa suportar uma causa que você concorde. Acho } \\
\text { que o caminho vem por aí, pq se depender dos órgãos como FIFA e CBF estamos } \\
\text { fadados a não ter solução alguma }\end{array}$ & $\begin{array}{c}\text { O setor privado como provedor de } \\
\text { mudanças com seu suporte a causas } \\
\text { sociais de interesse da sociedade. } \\
\text { Descrença dos órgãos oficiais neste } \\
\text { papel. }\end{array}$ \\
\hline ENT 12 & $\begin{array}{l}\text { Sim, mas nesse caso específico foi uma expansão do patrocínio à Seleção Masculina } \\
\text { motivada principalmente pela oportunidade de serem pioneiros. Isso, na minha visão, é o } \\
\text { melhor caminho, mais real de acontecer (tentar expandir contratos de patrocinadores } \\
\text { atuais) }\end{array}$ & $\begin{array}{l}\text { Ampliação das ações de um já } \\
\text { patrocinador do futebol, mas masculino. } \\
\text { Oportunidade de ser pioneiro. }\end{array}$ \\
\hline ENT 13 & $\begin{array}{l}\text { Sim, qualquer ação neste sentido é bem-vinda. É claro que a desigualdade de gênero } \\
\text { ainda é o maior empecilho para uma mudança. }\end{array}$ & $\begin{array}{l}\text { A desigualdade de gênero como } \\
\text { explicação para dificuldades de } \\
\text { mudanças }\end{array}$ \\
\hline ENT 14 & $\begin{array}{c}\text { Acredito que esta seja uma das formas de aumentar o patrocínio, mas não a única. As } \\
\text { marcas, no caso específico da Guaraná, sairiam "bem na foto" de se envolverem em uma } \\
\text { causa que precisa de incentivo, e ainda posariam ao lado de uma marca muito } \\
\text { importante, não apenas pelo seu tamanho como por ser também patrocinadora da } \\
\text { seleção brasileira há tantos anos. }\end{array}$ & $\begin{array}{l}\text { Associações de imagens das marcas } \\
\text { como positivas ao serem envolvidas em } \\
\text { uma causa que requer incentivo. }\end{array}$ \\
\hline ENT 15 & $\begin{array}{c}\text { Sim, é uma ação isolada, mas isoladamente não tem valor a longo prazo. Essas ações } \\
\text { teriam que ser associadas a políticas públicas e incentivo a patrocínios e } \\
\text { desenvolvimento não somente no âmbito privado. }\end{array}$ & $\begin{array}{l}\text { Ação isolada com efeito de curto prazo. } \\
\text { Requer políticas públicas de incentivo e } \\
\text { não apenas no âmbito privado. }\end{array}$ \\
\hline
\end{tabular}


Fonte: Autoria própria. Dados da pesquisa de campo.

Contudo, no conjunto das respostas há argumentos que ações desta natureza têm fôlego de curto prazo e que requerem ações de clubes e organizadores do futebol. Outros revelam descrença em relação às ações de órgãos oficiais ou públicos (organizadores do futebol), apostando no setor privado. Na tabela 11 é possível visualizar o resumo desses pontos.

Tabela 11: Resultado dos Especialistas em Relação à Ações da Iniciativa Privada (Guaraná Antárctica)

\begin{tabular}{|c|c|c|c|}
\hline & $\operatorname{sim}$ & $\mathrm{CP}$ & Quem? \\
\hline ENT 1 & 1 & & \\
\hline ENT 2 & 1 & & \\
\hline ENT 3 & 1 & & $\begin{array}{c}\text { Trabalho deve ser feito pelas } \\
\text { instituições responsáveis pelo } \\
\text { Futebol Feminino }\end{array}$ \\
\hline ENT 4 & 1 & & \\
\hline ENT 5 & 1 & 1 & \\
\hline ENT 6 & 1 & 1 & \\
\hline ENT 7 & 1 & & \\
\hline ENT 8 & 1 & & \\
\hline ENT 9 & 1 & & \\
\hline ENT 10 & 1 & 1 & \\
\hline ENT 11 & 1 & & $\begin{array}{c}\text { Se depender da FIFA e CBF } \\
\text { estamos fadados a não ter } \\
\text { solução alguma. }\end{array}$ \\
\hline ENT 12 & 1 & & \\
\hline ENT 13 & 1 & & \\
\hline ENT 14 & 1 & & \\
\hline \multirow[t]{3}{*}{ ENT 15} & 1 & 1 & Não somente no âmbito privado \\
\hline & 15 & 4 & \\
\hline & $100 \%$ & $27 \%$ & \\
\hline
\end{tabular}

Fonte: Autoria própria. Dados da pesquisa de campo.

Concluindo-se, pode-se finalizar que, diante de tal análise, ações como essa são benéficas para o crescimento do patrocínio no futebol feminino, apesar de serem um "tiro de curto prazo" /terem um fôlego curto. Pelo fato de haver divergências na resposta de alguns especialistas acerca de quem é o maior responsável por essas ações, entre a iniciativa privada e instituições responsáveis pelo futebol feminino, foi levado essa questão para a segunda rodada a fim de verificar a opinião especificamente desse ponto de todos os participantes. 


\subsubsection{Casos de sucesso no futebol feminino}

No futebol feminino brasileiro destacam-se dois times de São Paulo: Ferroviária e Corinthians. O primeiro já foi campeão 1 vez da Copa do Brasil, 2 vezes campeão do Brasileirão e 2 vezes campeão da Libertadores, enquanto a sua equipe masculina nunca conquistou nenhum título dos campeonatos citados. Já o segundo, por sua vez, na categoria feminina foi campeão 2 vezes pela Libertadores, 2 vezes campeão do Brasileirão, 2 vezes campeão do Paulistão e 1 vez campeão da Copa do Brasil. Na categoria masculina foi campeão 2 vezes da Copa do Mundo de Clubes da FIFA, 1 vez campeão das Libertadores, 7 vezes campeão do Brasileirão e 3 vezes campeão da Copa do Brasil. A partir disso, considerando suas respectivas performances no âmbito do futebol feminino, foi perguntado aos especialistas em que ambos os clubes se destacavam dos demais. Dentre as respostas, destacam-se:

"Eles possuem um investimento mais sólido na modalidade. Agora, outros clubes começaram também a investir em atletas e estrutura, o que pode ameaçar essa hegemonia tanto da Ferroviária quanto do Corinthians” (ENT 10).

"Gestão Profissional e muita atenção no extracampo - estrutura, condições de trabalho, capacitação profissional” (ENT 3).

"Investimento, profissionalização e pensamento estratégico próprio para o feminino, com profissionais e estrutura montadas especificamente para ofeminino", (ENT 15).

Novamente, para cada resposta obtida de cada especialista foi realizada uma síntese, com base no método da análise de conteúdo, conforme é possível visualizar na tabela 12 . A partir disso, agrupamentos foram realizados com o objetivo de facilitar a análise, conforme visto na tabela $13.27 \%$ dos especialistas afirmaram não ter conhecimento, $47 \%$ creem que tais resultados são devidos ao investimento, $27 \%$ creem que se devem à estrutura e gestão profissional dos times e $7 \%$ entendem que as equipes olham o futebol feminino como uma oportunidade de mercado.

Tabela 12: Respostas dos Especialistas sobre os Casos de Sucesso Ferroviária e Corinthians. 


\begin{tabular}{|c|c|c|}
\hline & Respostas & $\begin{array}{l}\text { Síntese da resposta com base no método da } \\
\text { análise de conteúdo }\end{array}$ \\
\hline ENT 1 & Não tenho conhecimento para elaborar muito nesse âmbito. & Sem conhecimento \\
\hline ENT 2 & Possivelmente por conta do nível de investimento & Hipótese: investimento \\
\hline ENT 3 & $\begin{array}{c}\text { Gestão Profissional e muita atenção no extracampo - estrutura, condições } \\
\text { de trabalho, capacitação profissional. }\end{array}$ & $\begin{array}{l}\text { Gestão profissional (estrutura, condições de } \\
\text { trabalho e capacitação profissional) }\end{array}$ \\
\hline ENT 4 & $\begin{array}{c}\text { Acredito que eles se destaquem dos demais pela organização interna e } \\
\text { projetos bem estruturados. }\end{array}$ & Organização interna e projetos bem estruturados \\
\hline ENT 5 & Não sei responder... & Sem conhecimento \\
\hline ENT 6 & Investimento. & Investimento \\
\hline ENT 7 & Não faço ideia. & Sem conhecimento \\
\hline ENT 8 & $\begin{array}{l}\text { O time chama-se Ferroviária (com "a") de Araraquara. Acredito que essas } \\
\text { equipes tenham um certo investimento, mas sem rivais a altura o esporte } \\
\text { não irá deslanchar }\end{array}$ & $\begin{array}{l}\text { Hipótese: investimento; por falta de competidores } \\
\text { a altura poderá não evoluir. }\end{array}$ \\
\hline ENT 9 & $\begin{array}{l}\text { São equipes de bom investimento. De origem distinta (creio que a } \\
\text { Ferroviária ainda tenha investimento também da prefeitura) } \\
\text { Há que se observar também que essa lista de títulos deve ser relativizada. } \\
\text { A Libertadores feminina, em que pese estar melhorando nos últimos anos, } \\
\text { ainda é um torneio de nível técnico inferior ao Paulista, por exemplo } \\
\text { Outro ponto é que são equipes que estão aí há alguns anos, antes da } \\
\text { obrigatoriedade, portanto possuem um certo know-how } \\
\text { Será interessante ver até onde vai a Ferroviária em termos de orçamento } \\
\text { posto que os mesmos têm crescido sensivelmente de um ano a outro. }\end{array}$ & $\begin{array}{l}\text { Investimento; equipes com anos de atuação, } \\
\text { portanto já com certo know-how. }\end{array}$ \\
\hline $\begin{array}{c}\text { ENT } \\
10\end{array}$ & $\begin{array}{l}\text { Eles possuem um investimento mais sólido na modalidade. Agora, outros } \\
\text { clubes começaram também a investir em atletas e estrutura, o que pode } \\
\text { ameaçar essa hegemonia tanto da Ferroviária quanto do Corinthians. }\end{array}$ & Investimento e de forma sólida \\
\hline $\begin{array}{c}\text { ENT } \\
11\end{array}$ & $\begin{array}{c}\text { Acho que ambos os times enxergam o futebol feminino como uma } \\
\text { oportunidade de mercado. O perfil do torcedor no Brasil hoje é composto } \\
\text { por } 43 \% \text { de mulheres (dados do IBOPE REPUCOM 2020), além de que e } \\
\text { um território novo a ser explorado, permitindo que clubes pequenos sejam } \\
\text { enormes e que times enormes tenham que se provar novamente. O futebol } \\
\text { tem que sair da mesmice, precisamos de novas ídolos, novos pontos de } \\
\text { vista e novos formatos / canais de comunicação. Cedo ou tarde essa } \\
\text { realidade vai cobrar os outros times do Brasil hoje... }\end{array}$ & $\begin{array}{l}\text { Clubes que enxergam o futebol feminino como } \\
\text { uma oportunidade de mercado. }\end{array}$ \\
\hline $\begin{array}{c}\text { ENT } \\
12\end{array}$ & $\begin{array}{l}\text { Não conheço o suficiente para opinar sobre as performances, mas o que } \\
\text { acompanhei por alto foi que num universo que ainda é bem amador, } \\
\text { projetos minimamente organizados e profissionais sobram e } \\
\text { consequentemente, tem uma performance superior. }\end{array}$ & Projetos e profissionais organizados \\
\hline $\begin{array}{c}\text { ENT } \\
13\end{array}$ & Investimento. & Investimento \\
\hline $\begin{array}{c}\text { ENT } \\
14\end{array}$ & Não conheço a fundo para dizer & Sem conhecimento \\
\hline $\begin{array}{c}\text { ENT } \\
15\end{array}$ & $\begin{array}{l}\text { Investimento, profissionalização e pensamento estratégico próprio para o } \\
\text { feminino, com profissionais e estrutura montadas especificamente para o } \\
\text { feminino. }\end{array}$ & $\begin{array}{l}\text { Investimento, profissionalização e estrutura } \\
\text { própria para a modalidade feminina }\end{array}$ \\
\hline
\end{tabular}

Fonte: Autoria própria. Dados da pesquisa de campo. 
Tabela 13: Resultado dos Especialistas sobre os Casos de Sucesso Ferroviária e Corinthians.

\begin{tabular}{|c|c|c|c|c|}
\hline & $\begin{array}{c}\text { Sem } \\
\text { conhecimento }\end{array}$ & Investimento & $\begin{array}{l}\text { Estrutura e } \\
\text { gestão } \\
\text { profissional }\end{array}$ & $\begin{array}{l}\text { O feminino } \\
\text { como uma } \\
\text { oportunidade de } \\
\text { mercado }\end{array}$ \\
\hline ENT 1 & 1 & & & \\
\hline ENT 2 & & 1 & & \\
\hline ENT 3 & & & 1 & \\
\hline ENT 4 & & & 1 & \\
\hline ENT 5 & 1 & & & \\
\hline ENT 6 & & 1 & & \\
\hline ENT 7 & 1 & & & \\
\hline ENT 8 & & 1 & & \\
\hline ENT 9 & & 1 & & \\
\hline ENT 10 & & 1 & & \\
\hline ENT 11 & & & & 1 \\
\hline ENT 12 & & & 1 & \\
\hline ENT 13 & & 1 & & \\
\hline ENT 14 & 1 & & & \\
\hline \multirow[t]{3}{*}{ ENT 15} & & 1 & 1 & \\
\hline & 4 & 7 & 4 & 1 \\
\hline & $27 \%$ & $47 \%$ & $27 \%$ & $7 \%$ \\
\hline
\end{tabular}

Fonte: Autoria própria. Dados da pesquisa de campo.

Esta pergunta recorreu a um exemplo de dois clubes brasileiros de futebol, com expressões bem distintas na modalidade masculina, mas ambos com grandes feitos na modalidade feminina. Neste caso, em especial, o de menor expressão na modalidade masculina e no âmbito nacional, Ferroviária, tem títulos nacionais e internacionais. Diferentes explicações foram apresentadas por cada participante. Surge neste conjunto de respostas argumentos de investimentos consistentes, profissionalização e infraestrutura adequada gerando tais resultados. A fim de obter um consenso entre todos os participantes diante dessas justificativas, essa pergunta foi para a segunda rodada.

\subsubsection{O papel da CBF no futebol feminino}

Há, por parte da CBF, movimentos para tentar diminuir as diferenças entre os gêneros no futebol. Em 2019, conforme visto no capítulo 2, a CBF determinou, através de um novo regulamento, que todas as equipes da primeira divisão do Campeonato Brasileiro Masculino 
precisam ter um time feminino adulto e, pelo menos, uma categoria de base. Diante disso, foi perguntado aos especialistas se eles acreditam que o futebol feminino precisa de imposições legais para se desenvolver e ser valorizado. Através da análise das respostas, a partir da síntese da análise de conteúdo, foi possível afirmar um certo consenso logo na primeira rodada. A Tabela 14 apresenta as respostas:

Tabela 14: Respostas dos Especialistas a respeito da Imposição feita pela CBF 


\begin{tabular}{|c|c|c|}
\hline & Respostas & $\begin{array}{l}\text { Síntese da resposta com base no método da } \\
\text { análise de conteúdo }\end{array}$ \\
\hline ENT 1 & $\begin{array}{l}\text { Não acho que tenha a ver com imposições legais, ainda que eu não fosse contra } \\
\text { elas eventualmente. Mas regulamentações de fomento e formação de produto } \\
\text { deveriam partir das próprias entidades reguladores do esporte. Elas são as mais } \\
\text { interessadas no aumento do alcance das modalidades e da geração de receita que } \\
\text { isso traria. }\end{array}$ & $\begin{array}{l}\text { Regulações de fomento e formação de } \\
\text { produto deveriam partir das entidades } \\
\text { reguladoras do esporte. }\end{array}$ \\
\hline ENT 2 & Sim. Para quebrar essa velha prática & Sim \\
\hline ENT 3 & $\begin{array}{c}\text { Sim, dada a cultura brasileira e o machismo arraigado no esporte e especialmente } \\
\text { no futebol, o futebol fem só apresentou crescimento e evolução após as medidas de } \\
\text { obrigatoriedade. Obrigatoriedade essa que iniciou com ações da FIFA, depois } \\
\text { CONMEBOL para depois passar a ser determinada pela CBF. }\end{array}$ & $\begin{array}{l}\text { Sim, apenas com medidas de } \\
\text { obrigatoriedade está tendo evolução. }\end{array}$ \\
\hline ENT 4 & $\begin{array}{c}\text { Sim, acredito que o futebol feminino brasileiro precise de imposições como esse. } \\
\text { Porém, não acredito que todos os times da } 1 \text { a Divisão do Campeonato Brasileiro } \\
\text { Masculino tenham condições financeiras de sustentar o time masculino mais Base e } \\
\text { um time Feminino + Base. Caso a CBF não os ajude de alguma maneira, as equipes } \\
\text { podem criar novos times Femininos + Base por } 1 \text { ou } 2 \text { anos e logo depois acabarem } \\
\text { por falta de investimento econômico. }\end{array}$ & $\begin{array}{l}\text { Sim, porém essa em específico pode não } \\
\text { ser sustentável (financeiramente) }\end{array}$ \\
\hline ENT 5 & $\begin{array}{c}\text { Não sei se a imposição é o melhor caminho. Faz com que os clubes tenham time } \\
\text { por ter. } \\
\text { O esporte precisa de desenvolvimento desde a formação de novos atletas até a } \\
\text { formação de grandes ídolos. Na resposta anterior foi comentado o sucesso do Time } \\
\text { Feminino da Ferroviária. }\end{array}$ & $\begin{array}{l}\text { Imposição não é o melhor caminho. Ter time } \\
\text { por ter. }\end{array}$ \\
\hline ENT 6 & $\begin{array}{l}\text { Não acho que nada que é obrigatório é saudável. Mas acho que alternativas são } \\
\text { sempre bem-vindas. }\end{array}$ & $\begin{array}{l}\text { Obrigatório não é saudável, mas alternativas } \\
\text { são bem-vindas }\end{array}$ \\
\hline ENT 7 & $\begin{array}{l}\text { Seria bonito se não fosse necessário, mas isso me parece um mal necessário para } \\
\text { estimular. Para incentivar uma coisa que todos sabem que é boa. Comparo essa } \\
\text { imposição com o cinto de segurança. Todos sabiam da sua necessidade e } \\
\text { benefícios, mas só passaram a usar quando foi imposto e as multas cresceram. }\end{array}$ & Mal necessário. \\
\hline ENT 8 & $\begin{array}{l}\text { Nesse momento acredito que sim, mas diante de tantas adversidades no futebol } \\
\text { masculino, é inviável investir no feminino que não traz retorno financeiro para o } \\
\text { clube.... É um investimento a longo prazo...e os dirigentes sempre pensam em } \\
\text { curtíssimo prazo. }\end{array}$ & Sim \\
\hline ENT 9 & $\begin{array}{l}\text { Não é que precise. Mas certamente está imposição, fruto de um movimento iniciado } \\
\text { pela FIFA, tem o poder de acelerar o.processo. Isso é bom mas há que se ter } \\
\text { cuidado com o ritmo das coisas evitando uma espécie de efeito bolha. }\end{array}$ & Não é que precise, mas acelera no processo \\
\hline ENT 10 & $\begin{array}{l}\text { A CBF nada mais fez do que seguir a determinação da Fifa e da Conmebol para } \\
\text { seus filiados. A obrigatoriedade de ter o time feminino para as equipes do masculino } \\
\text { é uma condição, hoje, para disputar torneios da Conmebol e da Fifa. Ambas } \\
\text { seguiram o que a Uefa determinou na Europa e que ajudou a desenvolver mais o } \\
\text { futebol feminino nos países do Velho Continente. }\end{array}$ & Sim, copiou de outros lugares \\
\hline ENT 11 & $\begin{array}{l}\text { Sim, acredito que seja necessária uma imposição legal. O futebol é uma profissão } \\
\text { como todas as outras, um mercado como qualquer outro, precisamos sim garantir } \\
\text { equidade de gênero a partir de órgãos regulamentadores. Minha única ressalva é } \\
\text { não achar esse regulamento o suficiente, por exemplo, o botafogo acabou de } \\
\text { desligar seu time sub-20 feminino por cair para a série B e o Flamengo possui um } \\
\text { contrato de licenciamento com a marinha, ou seja, o time do Flamengo e o time da } \\
\text { marinha com o nome do Flamengo emprestado. }\end{array}$ & Sim, necessário uma imposição legal \\
\hline ENT 12 & $\begin{array}{l}\text { Sim, sem dúvidas. Claro que se fosse espontâneo, seria ainda melhor. Mas é } \\
\text { necessário sim ser uma imposição. }\end{array}$ & Sim, necessário uma imposição legal \\
\hline ENT 13 & $\begin{array}{c}\text { Sim, as imposições legais cuidam do direito do cidadão e respingam lá nos clubes e } \\
\text { suas estruturas. }\end{array}$ & Sim \\
\hline
\end{tabular}




\begin{tabular}{|l|c|c|}
\hline ENT 14 & $\begin{array}{c}\text { Não acho que precise necessariamente, mas acredito que a obrigatoriedade auxilia } \\
\text { para que haja condição de igualdade. Se não houver saída a não ser cumprir uma } \\
\text { regra, os clubes investirão na modalidade e, com o tempo, a competitividade } \\
\text { aumentará, bem como a visibilidade }\end{array}$ & Sim \\
\hline ENT 15 & $\begin{array}{c}\text { Sim, mas acredito que não deveríamos chamar de imposição, mas sim de } \\
\text { direcionamento em política pública (via Profut). Para se desenvolver com certeza } \\
\text { isso é necessário, mas a valorização passa por instâncias mais subjetivas, que } \\
\text { acompanham a sociedade atual e a representatividade das mulheres no futebol. } \\
\text { Além da questão da formação de público, que pode levar anos. }\end{array}$ & Sim \\
\hline
\end{tabular}

Fonte: Autoria própria. Dados da pesquisa de campo.

Os especialistas concordam que alternativas são sempre bem-vindas no que diz respeito ao desenvolvimento da modalidade feminina. Alguns citaram que não deveria ser chamado de imposição, mas sim um mal necessário ou um direcionamento em política pública. Além disso, $20 \%$ dos especialistas afirmaram que o futebol feminino só apresentou crescimento e evolução após medidas de obrigatoriedade de forma geral. Nessa especificamente, a obrigatoriedade que se iniciou com as ações da FIFA, depois CONMEBOL para depois passar a ser determinada pela CBF. Dentre as respostas, destacam-se:

"Sim, mas acredito que não deveríamos chamar de imposição mas sim de direcionamento em política pública (via Profut). Para se desenvolver com certeza isso é necessário, mas a valorização passa por instâncias mais subjetivas, que acompanham a sociedade atual e a representatividade das mulheres no futebol. Além da questão da formação de público, que pode levar anos” (ENT 15).

"A CBF nada mais fez do que seguir a determinação da Fifa e da Conmebol para seus filiados. A obrigatoriedade de ter o time feminino para as equipes do masculino é uma condição, hoje, para disputar torneios da Conmebol e da Fifa. Ambas seguiram o que a Uefa determinou na Europa e que ajudou a desenvolver mais o futebol feminino nos países do Velho Continente” (ENT 10).

"Sería bonito se não fosse necessário, mas isso me parece um mal necessário para estimular. Para incentivar uma coisa que todos sabem que é boa. Comparo essa imposição com o cinto de segurança. Todos sabiam da sua necessidade e benefícios, mas só passaram a usar quando foi imposto e as multas cresceram” (ENT 7). 
Tabela 15: Resultado dos Especialistas a respeito da Imposição feita pela CBF

\begin{tabular}{|c|c|}
\cline { 2 - 2 } \multicolumn{1}{c|}{} & \multicolumn{1}{c|}{ Sim } \\
\hline ENT 1 & $\mathrm{X}$ \\
\hline ENT 2 & $\mathrm{X}$ \\
\hline ENT 3 & $\mathrm{X}$ \\
\hline ENT 4 & $\mathrm{X}$ \\
\hline ENT 5 & \\
\hline ENT 6 & \\
\hline ENT 7 & $\mathrm{X}$ \\
\hline ENT 8 & $\mathrm{X}$ \\
\hline ENT 9 & \\
\hline ENT 10 & $\mathrm{X}$ \\
\hline ENT 11 & $\mathrm{X}$ \\
\hline ENT 12 & $\mathrm{X}$ \\
\hline ENT 13 & $\mathrm{X}$ \\
\hline ENT 14 & \\
\hline ENT 15 & $\mathrm{X}$ \\
\cline { 2 - 2 } & $\mathbf{1 1}$ \\
\hline & $\mathbf{7 3} \%$ \\
&
\end{tabular}

Fonte: Autoria própria. Dados da pesquisa de campo

Analisando as respostas entre os respondentes, concluiu-se que um consenso foi alcançado, onde $73 \%$ dos especialistas afirmaram que essas imposições servem como um estímulo e uma forma de aceleração no processo, além de auxiliar para que haja condições de igualdade. Dessa forma, a questão foi encerrada e não levada para a segunda rodada.

\subsubsection{Machismo na sociedade brasileira}

Um questionamento foi feito para conhecer a opinião dos especialistas a respeito da existência ou não de preconceito no cenário do futebol brasileiro, ao se observar tantas diferenças de divulgação e investimentos entre as categorias feminina e masculina, mesmo sendo o Brasil conhecido como o país do futebol. Dentre as respostas, destacam-se:

"Sim, a cultura brasileira é machista, patriarcal. Já se tem um futebol masculino que domina completamente a área esportiva, seja na imprensa, seja nos campinhos e escolinhas, seja no consumo de produtos de clubes. O feminino vem sobrevivendo há 
décadas, e conseguindo respirar um pouco mais nos últimos 3 anos, ainda há um longo caminho para o fortalecimento e autonomia, e isso passa pela quebra de paradigmas da sociedade em relação à mulher como um todo" (ENT 3).

"Acho que o assunto está sendo cada vez mais discutido e os posicionamentos sendo mais incisivos. O futebol feminino vem chegando com "o pé na porta", e de certa forma obrigando que se fale dele. Porém ainda vejo muito preconceito com a modalidade. São crenças de que a mulher é mais fraca, de que não sabe jogar bola, entre outras" (ENT 14).

Nessa questão, novamente a partir do método de análise de conteúdo, foi encontrado um elevado nível de consenso, com 93\% de concordância, conforme é possível visualizar na tabela 16 e 17. Eles afirmaram que existe preconceito no cenário do futebol feminino brasileiro. Alguns citaram que, apesar de ser uma sociedade machista, é possível visualizar uma evolução nos últimos anos. A única resposta diferente não foi no sentido contrário exatamente, mas na semântica: costume VS preconceito.

"Não diria preconceito. Todos nascemos com o futebol masculino aí. Na infância, quando uma menina era boa de bola, já taxaram ela de macho. Uma barreira cultural que vcs, mulheres estão enfrentando e vai demorar para vencer. Não é uma coisa que vc acorda um dia e tudo mudou. É um trabalho de formiguinhas. Vai vencer e as coisas vão mudar, mas é uma luta árdua. Assim como foi de os pobres entrarem no futebol, depois os negros e assim em diante. Sugestão: tem uma série na Netflix sobre o início dos campeonatos ingleses de futebol. No início era coisa de ricos" (ENT 7).

Tabela 16: Respostas dos Especialistas sobre Existência de Machismo no Futebol 
ENT 1 1 O futebol é continuação de uma sociedade machista, ainda que tendo avanços relevantes nos últimos anos. O futebol não vai mudar isso por si. Ele deve fazer medidas afirmativas, sim, e deve investir no produto, se não pelo evidente da questão de igualdade, que já deveria ser suficiente, mas pelo menos por inteligência de mercado. O mercado feminino é um dos maiores segmentos para expansão e geração de novas riquezas.

\begin{tabular}{|c|c|}
\hline ENT 2 & $\begin{array}{r}\text { Sem dúvida! O Brasil é um país tremendamente preconceituoso, não só } \\
\text { com as mulheres, mas também com outros grupos. }\end{array}$ \\
\hline
\end{tabular}

ENT 3 Sim, a cultura brasileira é machista, patriarcal. Já se tem um futebol masculino que domina completamente a área esportiva, seja na imprensa, seja nos campinhos e escolinhas, seja no consumo de produtos de clubes. O feminino vem sobrevivendo ha décadas, e conseguindo respirar um pouco mais nos últimos 3 anos, ainda há um longo caminho para o fortalecimento e autonomia, e isso passa pela quebra de paradigmas da sociedade em relação a mulher como um todo.

\begin{tabular}{|c|c|c|}
\hline ENT 4 & $\begin{array}{c}\text { Acredito que sim. Acredito que ainda existe preconceito quanto ao futebol } \\
\text { feminino e futebol envolvendo mulheres. }\end{array}$ & Sim \\
\hline ENT 5 & $\begin{array}{c}\text { Sem dúvidas. O futebol é feito de rivalidade e competitividade. O futebol } \\
\text { feminino precisaria de algumas adaptações para tornar o esporte mais } \\
\text { atrativo }\end{array}$ & Sim \\
\hline ENT 6 & $\begin{array}{c}\text { Não sei se a palavra é preconceito. Acho que o esporte brasileiro, como um } \\
\text { todo, é pouco explorado e com recursos escassos. (Tirando o futebol } \\
\text { masculino, é claro) }\end{array}$ & $\begin{array}{l}\text { Preconceito não é a palavra. E o negócio não é o } \\
\text { futebol feminino, e sim esporte brasileiro como um } \\
\text { todo }\end{array}$ \\
\hline ENT 7 & $\begin{array}{l}\text { Não diria preconceito. É costume mesmo. Todos nascemos com o futebol } \\
\text { masculino aí. Na infância, quando uma menina era boa de bola, já taxavam } \\
\text { ela de macho. Uma barreira cultural que vocês, mulheres estão enfrentando } \\
\text { e vai demorar para vencer. Não é uma coisa que vc acorda um dia e tudo } \\
\text { mudou. É um trabalho de formiguinhas. Vai vencer e as coisas vão mudar, } \\
\text { mas é uma luta árdua. Assim como foi de os pobres entrarem no futebol, } \\
\text { depois os negros e assim em diante. Sugestão: tem uma série na Netflix } \\
\text { sobre o início dos campeonatos ingleses de futebol. No início era coisa de } \\
\text { ricos. }\end{array}$ & Preconceito não, é costume. \\
\hline ENT 8 & $\begin{array}{l}\text { Muito preconceito...o negócio futebol feminino ainda é algo que não gera } \\
\text { lucro por isso a dificuldade de deslanchar, hoje ela é encarada como } \\
\text { custo...Já o futebol masculino gera milhões e nem se compara...é uma luta } \\
\text { injusta... }\end{array}$ & $\begin{array}{c}\text { Sim. Luta injustiça. Feminino }=\text { custo e masculino }= \\
\text { gera milhões }\end{array}$ \\
\hline ENT 9 & $\begin{array}{l}\text { O Brasil é um país machista. O futebol uma espécie de lócus privilegiado } \\
\text { para a manifestação desse machismo. E sim, há muito preconceito. } \\
\text { Dito isso, não creio que valores comparativos com o masculino sejam bons } \\
\text { parâmetros de avaliação pelas razões anteriormente expostas. }\end{array}$ & $\begin{array}{l}\text { Machista, preconceito. Não é bom parâmetro } \\
\text { comparar com o masculino }\end{array}$ \\
\hline ENT 10 & $\begin{array}{l}\text { Com certeza ainda há muito preconceito. Tanto na parte da mídia quanto do } \\
\text { torcedor, o que reflete por fim nos investimentos em patrocínio. Acredito } \\
\text { que, no médio prazo, essas diferenças tendem a ser reduzidas, o que vai } \\
\text { ampliar o interesse no futebol feminino como um todo. }\end{array}$ & $\begin{array}{l}\text { Sim, refletindo nos investimentos em patrocínio. } \\
\text { Médio prazo tende a diminuir. }\end{array}$ \\
\hline ENT 11 & $\begin{array}{c}\text { Sim. A expressão pais do futebol vem de uma luta contra o racismo por } \\
\text { parte dos brasileiros, e um processo de superar o complexo de vira-lata que } \\
\text { tínhamos no início do último século. Com o tempo a nossa sociedade } \\
\text { conservadora pegou uma expressão de empoderamento de classes sociais } \\
\text { mais baixas e a transformou em algo pejorativo, como se não fosse } \\
\text { importante. O Brasil é misógino, e o preconceito contra as mulheres sempre } \\
\text { esteve lá, cabe a nós ressignificar o que significa ser o pais do futebol, } \\
\text { através de ações concretas, tanto legais, esportivas ou culturais, para } \\
\text { garantiria equidade. A diferença de investimento entre essas categorias vem } \\
\text { historicamente de um local de preconceito e é necessário criar medidas } \\
\text { para combater isso. }\end{array}$ & $\begin{array}{l}\text { Sim! Necessário ações concretas para garantir } \\
\text { equidade, criar medidas para combater isso }\end{array}$ \\
\hline
\end{tabular}




\begin{tabular}{|c|c|c|}
\hline ENT 12 & $\begin{array}{c}\text { Sim, há muito preconceito, mas também há uma grande falta de } \\
\text { conhecimento do real potencial de retorno da modalidade do futebol } \\
\text { feminino. }\end{array}$ & Sim! \\
\hline ENT 13 & $\begin{array}{c}\text { Sim, o movimento feminino veio para ficar e espero muito que as mulheres } \\
\text { consigam o seu espaço na sociedade e possam ser tratadas iguais aos } \\
\text { homens. Isso irá melhorar e evoluir no quesito esporte e condições iguais } \\
\text { para homens e mulheres. }\end{array}$ & Sim! \\
\hline ENT 14 & $\begin{array}{l}\text { Acho que o assunto está sendo cada vez mais discuto e os } \\
\text { posicionamentos sendo mais incisivos. O futebol feminino vem chegando } \\
\text { com "o pé na porta", e de certa forma obrigando que se fale dele. Porém } \\
\text { ainda vejo muito preconceito com a modalidade. São crenças de que a } \\
\text { mulher é mais fraca, de que não sabe jogar bola, entre outras }\end{array}$ & Sim! \\
\hline ENT 15 & $\begin{array}{c}\text { Sim, ainda há o preconceito, que reflete o próprio preconceito da sociedade } \\
\text { no tratamento com as mulheres. Também é importante considerar que } \\
\text { essas diferenças ao longo dos anos produziram diferenças no jogo em si } \\
\text { (qualidade técnica e competitividade) e de seu entorno (alcance das } \\
\text { competições, qualidade de transmissão etc.). }\end{array}$ & $\begin{array}{c}\text { Sim, refletindo em diferenças dos jogos em si e de } \\
\text { seu entorno }\end{array}$ \\
\hline
\end{tabular}

Fonte: Autoria própria. Dados da pesquisa de campo.

Tabela 17: Resultado dos Especialistas sobre Existência de Machismo no Futebol

\begin{tabular}{|l|c|}
\hline & Sim \\
\hline ENT 1 & 1 \\
\hline ENT 2 & 1 \\
\hline ENT 3 & 1 \\
\hline ENT 4 & 1 \\
\hline ENT 5 & 1 \\
\hline ENT 6 & 1 \\
\hline ENT 7 & \\
\hline ENT 8 & 1 \\
\hline ENT 9 & 1 \\
\hline ENT 10 & 1 \\
\hline ENT 11 & 1 \\
\hline ENT 12 & 1 \\
\hline ENT 13 & 1 \\
\hline ENT 14 & 1 \\
\hline ENT 15 & 1 \\
\hline
\end{tabular}

Fonte: Autoria própria. Dados da pesquisa de campo. 
A partir do elevado consenso, a questão foi encerrada na primeira rodada.

\subsubsection{Patrocínio nas modalidades feminina e masculina}

Para concluir o questionário inicial, foi perguntado aos especialistas, segundo à experiência de cada um, quais são os principais motivos pelos quais empresas patrocinadoras da modalidade de futebol masculina não patrocinam a modalidade feminina. Esta pergunta procurou reforçar, de modo mais enfático, as razões pelas quais a modalidade feminina de futebol recebe menor atenção e recursos do que a modalidade masculina, no Brasil. Dentre as respostas, destacam-se:

Falta de credibilidade a nível organizacional e estrutural (ligas fracas, falta de atenção por parte da confederação) e problemas culturais (machismo por parte das pessoas que têm a tomada de decisão)” (ENT 12).

"Receio dos espaços e retornos que possam ter para uso e associação das suas marcas. O Fut Fem ainda é uma aposta e o Futebol brasileiro (masculino) ainda não tem a profissionalização necessária para garantir o retorno que as marcas gostariam” (ENT 3).

"O mercado de patrocínio hoje é um mercado de mídia e visibilidade. Vc deixa de comprar mídia tradicional para adquirir espaço em backdrop, camisa e etc. os jogos femininos não estão em muitos canais e o retorno é pequeno para o investimento em share of mind" (ENT 11).

Novamente, através da síntese da resposta com base no método da análise de conteúdo a partir das respostas obtidas, agrupamentos foram realizados com o objetivo de facilitar a análise. A tabela 18 e 19 apresenta os resultados.

Tabela 18: Respostas dos Especialistas sobre as Diferenças do Patrocínio entre as Modalidades Masculina e Feminina.

\begin{tabular}{|l|l|c|}
\hline Respostas & $\begin{array}{c}\text { Síntese da resposta com base no } \\
\text { método da análise de conteúdo }\end{array}$ \\
\hline
\end{tabular}




\begin{tabular}{|c|c|c|}
\hline ENT 1 & $\begin{array}{l}\text { O produto tem muito menos alcance e interesse social. A mudança tem } \\
\text { que vir de fora para dentro para isso diminuir. Enquanto isso, contudo, } \\
\text { o futebol precisa fazer sua parte e ampliar a presença feminina e se } \\
\text { preparar para receber essas mudanças urgentes que vêm se } \\
\text { materializando no tecido social nos últimos anos, ainda bem. }\end{array}$ & $\begin{array}{l}\text { Falta de alcance (visibilidade?) e falta de } \\
\text { interesse social. A mudança deve partir } \\
\text { da sociedade }\end{array}$ \\
\hline ENT 2 & $\begin{array}{c}\text { Mais uma vez, caímos na mesma resposta: Os meios de comunicação } \\
\text { apenas dão visibilidade para as modalidades esportivas praticadas por } \\
\text { homens e aas marcas querem exposição quando patrocinam uma } \\
\text { modalidade esportiva. }\end{array}$ & $\begin{array}{l}\text { Os meios de comunicação apenas dão } \\
\text { visibilidade para as modalidades } \\
\text { esportivas praticadas por homens }\end{array}$ \\
\hline ENT 3 & $\begin{array}{c}\text { Receio dos espaços e retornos que possam ter para uso e associação } \\
\text { das suas marcas. O Fut. Fem ainda é uma aposta e o Futebol } \\
\text { brasileiro (masculino) ainda não tem a profissionalização necessária } \\
\text { para garantir o retorno que as marcas gostariam. }\end{array}$ & $\begin{array}{l}\text { Incerteza sobre retornos e baixo nível de } \\
\text { profissionalização }\end{array}$ \\
\hline ENT 4 & $\begin{array}{l}\text { Retorno financeiro baixo, pouca audiência e o produto futebol ainda } \\
\text { não é visto como um produto bom. }\end{array}$ & $\begin{array}{l}\text { Baixo retorno, pouca audiência, } \\
\text { "produto" não são bom. }\end{array}$ \\
\hline ENT 5 & Ausência de ídolos, competitividade baixa, visibilidade nula. & $\begin{array}{l}\text { Visibilidade nula, "produto" ruim, sem } \\
\text { ídolos. }\end{array}$ \\
\hline ENT 6 & Acredito que visibilidade. & Visibilidade \\
\hline ENT 7 & Simples assim - investimento $\mathrm{x}$ retorno & Baixo retorno \\
\hline ENT 8 & Visibilidade e retorno! & Visibilidade e retorno \\
\hline ENT 9 & Visibilidade & Visibilidade \\
\hline ENT 10 & $\begin{array}{l}\text { Acho que falta um projeto definido para o patrocínio, o que faz com } \\
\text { que, como a exposição do futebol feminino é menor, a empresa não se } \\
\text { interesse por manter o aporte também na equipe feminina. Além disso, } \\
\text { o fato de os clubes venderem as propriedades separadamente ajuda a } \\
\text { ficar mais claro que o patrocínio é limitado ao time masculino. }\end{array}$ & $\begin{array}{l}\text { Falta de projeto definido para o } \\
\text { patrocínio, visibilidade e foco no } \\
\text { masculino }\end{array}$ \\
\hline ENT 11 & $\begin{array}{l}\text { O mercado de patrocínio hoje é um mercado de mídia e visibilidade. Vc } \\
\text { deixa de comprar mídia tradicional para adquirir espaço em backdrop, } \\
\text { camisa e etc. Os jogos femininos não estão em muitos canais e o } \\
\text { retorno é pequeno para o investimento em share of mind. }\end{array}$ & Visibilidade e retorno \\
\hline ENT 12 & $\begin{array}{l}\text { Falta de credibilidade a nível organizacional e estrutural (ligas fracas, } \\
\text { falta de atenção por parte da confederação) e problemas culturais } \\
\text { (machismo por parte das pessoas que tem a tomada de decisão). }\end{array}$ & $\begin{array}{l}\text { Falta de credibilidade nos âmbitos } \\
\text { organizacional e estrutural; machismo }\end{array}$ \\
\hline ENT 13 & Exposição da marca. Apelo pelo esporte feminino é pequeno. & Visibilidade \\
\hline ENT 14 & $\begin{array}{c}\text { Estas empresas não estão preocupadas em se associar com uma } \\
\text { modalidade que recebe pouca visibilidade pois não enxergam } \\
\text { benefícios que a associação pode trazê-las }\end{array}$ & Visibilidade \\
\hline ENT 15 & $\begin{array}{c}\text { Por falta de retorno imediato, a falta de informação disponível } \\
\text { (relatórios de análise de comportamento, potencial de venda/retorno) e } \\
\text { muitas vezes por subestimarem o potencial de engajamento de seus } \\
\text { clientes com o futebol feminino. }\end{array}$ & $\begin{array}{l}\text { Retorno, falta de informação e } \\
\text { subestimação do potencial de } \\
\text { engajamento }\end{array}$ \\
\hline
\end{tabular}

Fonte: Autoria própria. Dados da pesquisa de campo.

Tabela 19: Resultado Diferenças do Patrocínio entre as Modalidades 


\begin{tabular}{|c|c|c|c|c|c|c|c|}
\hline & $\begin{array}{c}\text { Baixo } \\
\text { alcance; } \\
\text { visibilidade }\end{array}$ & $\begin{array}{l}\text { Baixo } \\
\text { retorno }\end{array}$ & $\begin{array}{c}\text { Falta de } \\
\text { credibilidade; nível } \\
\text { organizacional e } \\
\text { estrutural ruins }\end{array}$ & $\begin{array}{l}\text { Falta de projeto } \\
\text { definido para o } \\
\text { patrocínio }\end{array}$ & $\begin{array}{c}\text { Falta de } \\
\text { interesse da } \\
\text { sociedade }\end{array}$ & Preconceito & $\begin{array}{c}\text { Falta de } \\
\text { informação e } \\
\text { consequente } \\
\text { subestimação } \\
\text { de potencial }\end{array}$ \\
\hline ENT 1 & 1 & & & & 1 & & \\
\hline ENT 2 & 1 & & & & & 1 & \\
\hline ENT 3 & & 1 & 1 & & & & \\
\hline ENT 4 & 1 & 1 & 1 & & & & \\
\hline ENT 5 & 1 & & 1 & & & & \\
\hline ENT 6 & 1 & & & & & & \\
\hline ENT 7 & & 1 & & & & & \\
\hline ENT 8 & 1 & 1 & & & & & \\
\hline ENT 9 & 1 & & & & & & \\
\hline ENT 10 & 1 & & & 1 & & & \\
\hline ENT 11 & 1 & 1 & & & & & \\
\hline ENT 12 & & & 1 & & & 1 & \\
\hline ENT 13 & 1 & & & & & & \\
\hline ENT 14 & 1 & & & & & & \\
\hline \multirow[t]{3}{*}{ ENT 15} & & 1 & & & & & 1 \\
\hline & 11 & 6 & 4 & 1 & 1 & 2 & 1 \\
\hline & $73 \%$ & $40 \%$ & $27 \%$ & $7 \%$ & $7 \%$ & $13 \%$ & $7 \%$ \\
\hline
\end{tabular}

Fonte: Elaboração própria (2021)

Revelam-se neste conjunto de respostas diversos argumentos que incluem: baixo alcance ou visibilidade (73\%), baixo retorno dos investimentos (40\%), baixo índice de credibilidade, seja por nível organizacional, seja por serem "produtos" ruins, ausência de projetos específicos de patrocínio, falta de interesse por parte da sociedade, preconceito e falta de informação, o que leva à subestimação dos potenciais engajamentos das marcas com o público desta modalidade. A fim de obter um maior consenso nas justificativas, a questão foi levada para a segunda rodada.

\subsection{Segunda Rodada}

A segunda rodada da pesquisa de campo foi realizada através de um documento no formato WORD personalizado para cada participante da primeira rodada. Ele continha as cinco questões que não apresentaram um consenso inicial. Para cada participante foram expostas as tabelas apresentadas na seção 4.1, tanto aquelas que apresentavam as respostas de cada 
entrevistado de forma anônima quanto o quadro dos resultados. Essa rodada, a partir da síntese das respostas obtidas, tinha como objetivo que os especialistas acrescentassem ou reconsiderassem algo em suas respostas, buscando encontrar um maior consenso nas justificativas apresentadas na primeira rodada. Para melhor análise, em cada questão dessa rodada foi acrescido em vermelho nas tabelas, como por exemplo na tabela a seguir de número 21, os participantes que incluíram alguma informação em suas respostas.

Os documentos foram enviados por e-mail ou WhatsApp, de acordo com a preferência do especialista. Dos 15 que responderam o formulário na primeira rodada, apenas 6 participaram respondendo o documento enviado nesta segunda rodada.

\subsubsection{Diferença salarial entre atletas dos gêneros feminino e masculino}

Esta questão tinha como foco a discrepância de renda entre dois jogadores brasileiros de destaque no futebol, ambos de renome internacional, mas de gêneros distintos. Marta com maior número de prêmios internacionais; Neymar com maior faturamento. Foram identificadas diferentes explicações apresentadas por cada participante. A partir da resposta do especialista e analisando as respostas dos demais, bem como o quadro resumo, foi solicitado que eles, caso desejassem, se posicionassem novamente, podendo acrescentar ou reconsiderar a sua respectiva resposta. As respostas dos especialistas participantes na segunda rodada são expostas na tabela 20 .

Tabela 20: Respostas dos Especialistas (Segunda Rodada) sobre Diferença Salarial

\begin{tabular}{|c|c|c|}
\hline & Respostas & Algo a acrescentar? \\
\hline ENT 1 & Concordo com os quatro pontos mais citados. Nada mais a declarar & Todos os quadrantes \\
\hline ENT 3 & Nada a acrescentar & $\begin{array}{c}\text { Acrescentaria na minha resposta a proibição de mulheres poderem praticar futebol no } \\
\text { passado como mais um fator para discrepância entre os dois mercados. As } \\
\text { mulheres tiveram que "remar" muito mais em muito menos tempo para conseguir ser } \\
\text { ouvidas e "liberadas" para a prática do esporte. Algo totalmente fora de sentido e } \\
\text { bizarramente feito no passado. O Futebol masculino é o que é hoje porque tem anos e } \\
\text { anos de prática e desenvolvimento. Itens que ainda estão muito atrasados na } \\
\text { modalidade feminina pelos pontos que eu mencionei anteriormente. }\end{array}$ \\
\hline
\end{tabular}


Sim. O principal fator a meu ver é a ausência de receitas similares. O "bolo" a se dividir é muito menor. Mas este principal fator decorre dos demais, obviamente. A

ENT 9 visibilidade é menor porque o desenvolvimento é tardio. Então a questão histórica, inclusive referente ao período que o futebol feminino foi proibido no Brasil e em outras partes e esquecido pela FIFA, entre outros, pesa. E o que dá origem a esta história é

Questão histórica e o preconceito

\begin{tabular}{|c|c|c|}
\hline & $\begin{array}{c}\text { partes e esquecido pela FIFA, entre outros, pesa. E o que dá origem a esta história é } \\
\text { a questão de gênero. }\end{array}$ & \\
\hline ENT 14 & Incluo a questão do machismo muito evidente no Brasil & Preconceito/Machismo \\
\hline ENT 15 & $\begin{array}{l}\text { Sim, a menor visibilidade é também um dos itens dessa conta em que o resultado é a } \\
\text { diferença de ingressos para profissionais similares em relevância dentro de suas } \\
\text { modalidades. }\end{array}$ & Visibilidade \\
\hline
\end{tabular}

Fonte: Autoria própria. Dados da pesquisa de campo.

Tabela 21: Resultado Diferença Salarial

\begin{tabular}{|c|c|c|c|c|}
\hline & $\begin{array}{c}\text { Preconceito - } \\
\text { machismo }\end{array}$ & Visibilidade & $\begin{array}{l}\text { Retorno do } \\
\text { mercado/receitas } \\
\text { diferentes }\end{array}$ & $\begin{array}{l}\text { Herança } \\
\text { histórica }\end{array}$ \\
\hline ENT 1 & 1 & 1 & 1 & 1 \\
\hline ENT 2 & & 1 & & \\
\hline ENT 3 & & 1 & & \\
\hline ENT 4 & & & 1 & 1 \\
\hline ENT 5 & & 1 & & \\
\hline ENT 6 & & 1 & & \\
\hline ENT 7 & & 1 & & \\
\hline ENT 8 & & 1 & 1 & \\
\hline ENT 9 & 1 & 1 & 1 & 1 \\
\hline ENT 10 & & & 1 & 1 \\
\hline ENT 11 & 1 & 1 & 1 & 1 \\
\hline ENT 12 & 1 & 1 & & 1 \\
\hline ENT 13 & 1 & 1 & & \\
\hline ENT 14 & 1 & 1 & 1 & \\
\hline ENT 15 & 1 & 1 & 1 & 1 \\
\hline & 7 & 13 & 8 & 7 \\
\hline & $47 \%$ & $87 \%$ & $53 \%$ & $47 \%$ \\
\hline
\end{tabular}

Fonte: Autoria própria. Dados da pesquisa de campo.

Dessa forma, um maior consenso foi alcançado nas justificativas perante a diferença salarial entre os maiores ícones do futebol brasileiro. $87 \%$ apontaram a diferença de visibilidade, $53 \%$ do retorno que eles trazem, e $47 \%$ para o assunto do preconceito/machismo e a herança histórica. A questão foi encerrada devido ao maior nível de consenso no quesito "visibilidade" (acima de 67\% de consenso). 


\subsubsection{Subvalorização dos patrocínios na modalidade feminina}

$\mathrm{Na}$ primeira rodada foi visto que os especialistas expuseram diferentes argumentos em suas respectivas respostas em relação à subvalorização dos patrocínios na modalidade feminina: a falta de visibilidade (60\%), a discriminação (40\%), a herança histórica (33\%), o menor interesse do público (27\%) e restrições estruturais da modalidade (20\%). A partir dos resultados, os especialistas tiveram a oportunidade de se posicionar novamente no assunto. As respostas são apresentadas a seguir:

Tabela 22: Respostas dos Especialistas (Segunda Rodada) - Subvalorização dos Patrocínios

\begin{tabular}{|c|c|c|}
\hline & Respostas & Algo a acrescentar? \\
\hline ENT 1 & $\begin{array}{l}\text { Concordo com os pontos citados do quadro resumo. Reforço a questão do } \\
\text { menor interesse não é por conta da qualidade do futebol feminino em sí, } \\
\text { mas pelo pelo fato das mídias e do mercado não darem a importância a } \\
\text { categoria e não por conta do desinteresse do público mesmo. }\end{array}$ & $\begin{array}{l}\text { Mercado recente/questões } \\
\text { históricas e restrições } \\
\text { estruturais }\end{array}$ \\
\hline ENT 3 & $\begin{array}{l}\text { Incluiria na resposta que o engajamento com a seleção feminina ocorre de } \\
\text { forma sazonal, mais especificamente no período da Copa. Tal } \\
\text { engajamento não perdura para os anos seguintes, não tendo uma } \\
\text { constância de interesse do publico que por sua vez traria poderia gerar } \\
\text { maior interesse de investidores para a sustentabilidade da modalidade. }\end{array}$ & \\
\hline ENT 4 & $\begin{array}{c}\text { Acredito que as respostas para essa pergunta são as mesmas ou bem } \\
\text { parecidas para a pergunta anterior. O "produto" futebol feminino ainda é } \\
\text { embrionário e está caminhando ainda, se desenvolvendo. Obviamente } \\
\text { que se você tiver um maior incentivo dos times e federações, essa } \\
\text { "caminha" aumenta e acelera. Porém, o momento em que } 95 \% \text { dos times } \\
\text { brasileiros hoje se encontra é bem caótico, para não falar que estão } \\
\text { falidos. O que dificulta os times a investirem em seus times femininos, } \\
\text { portanto, acredito que quem deveria auxiliar o futebol feminino nesse } \\
\text { momento são as federações e a CBF. }\end{array}$ & $\begin{array}{l}\text { Menor exposição/visibilidade } \\
\text { e Mercado recente/questões } \\
\text { histórica }\end{array}$ \\
\hline ENT 9 & $\begin{array}{l}\text { Nada a acrescentar, exceto a mesma lógica da observação anterior. Gera } \\
\text { menos receita por ter menos visibilidade, menos visibilidade por ser mais } \\
\text { novo, é mais novo dado os preconceitos que conhecemos. }\end{array}$ & Discriminação/machismo \\
\hline ENT 14 & $\begin{array}{l}\text { O caso da Copa do Mundo foi um evento isolado, pois esse mesmo } \\
\text { público que se envolveu naquela data não se envolve o resto do ano. O } \\
\text { mesmo acontece com a Copa do Mundo masculina: um número maior de } \\
\text { pessoas se demonstra envolvida com o evento durante o período de } \\
\text { realização dele e, no resto do ano, não se envolvem com a modalidade. A } \\
\text { falta de exposição e visibilidade funcionam sim como motor para essa } \\
\text { percepção diferenciada mas fazem parte de um ciclo vicioso. Por } \\
\text { questões físicas e biológicas que diferenciam os dois sexos, poderia haver } \\
\text { um ajuste na prática da modalidade, como por exemplo traves menores. } \\
\text { Não acho que o futebol feminino não seja atraente mais há uma raiz } \\
\text { histórica de preconceito entranhada. }\end{array}$ & Discriminação/machismo \\
\hline
\end{tabular}

Fonte: Autoria própria. Dados da pesquisa de campo 
Tabela 23: Resultado sobre a Subvalorização dos Patrocínios da Modalidade Feminina do Futebol

\begin{tabular}{|c|c|c|c|c|c|}
\hline & $\begin{array}{c}\text { Discriminação, } \\
\text { machismo }\end{array}$ & $\begin{array}{c}\text { Menor } \\
\text { exposição/visibilidade }\end{array}$ & $\begin{array}{c}\text { Menor } \\
\text { interesse } \\
\text { do } \\
\text { público }\end{array}$ & $\begin{array}{l}\text { Mercado } \\
\text { recente, } \\
\text { herança } \\
\text { histórica }\end{array}$ & $\begin{array}{l}\text { Restrições } \\
\text { estruturais }\end{array}$ \\
\hline ENT 1 & 1 & 1 & 1 & 1 & 1 \\
\hline ENT 2 & 1 & 1 & & & \\
\hline ENT 3 & & & & 1 & 1 \\
\hline ENT 4 & & 1 & & 1 & \\
\hline ENT 5 & & 1 & 1 & & \\
\hline ENT 6 & & 1 & 1 & & \\
\hline ENT 7 & & & & 1 & 1 \\
\hline ENT 8 & & 1 & 1 & & \\
\hline ENT 9 & 1 & 1 & & 1 & \\
\hline ENT 10 & & 1 & & & \\
\hline ENT 11 & 1 & & & & \\
\hline ENT 12 & 1 & 1 & & 1 & 1 \\
\hline ENT 13 & 1 & & & & \\
\hline ENT 14 & 1 & 1 & & & \\
\hline ENT 15 & 1 & 1 & & 1 & \\
\hline & 8 & 11 & 4 & 7 & 4 \\
\hline & $53 \%$ & $73 \%$ & $27 \%$ & $47 \%$ & $27 \%$ \\
\hline
\end{tabular}

Fonte: Autoria própria. Dados da pesquisa de campo

Segundo os dados expostos na tabela 23, um maior consenso foi alcançado nas justificativas apresentadas entre os especialistas. A falta de visibilidade (73\%) foi a explicação que revelou um maior nível/grau de consenso. A discriminação (53\%), a herança histórica (47\%) e as restrições estruturais da modalidade (27\%) foram outras razões apresentadas, embora sem consenso.

Em relação ao menor interesse do público, o ENT 1 fez questão de deixar claro que essa questão não é por conta da qualidade do futebol feminino, mas pelo fato das mídias e do mercado não darem a importância a categoria, conforme é possível visualizar na tabela 23 . A questão foi encerrada devido ao alcance de consenso no quesito "visibilidade".

\subsubsection{Ações de patrocínio por parte da iniciativa privada}

A partir das respostas obtidas na primeira rodada, um consenso foi alcançado em relação aos méritos da ação realizada pela marca Guaraná Antártica, conforme analisado no 
item 4.1.2.5. No conjunto das respostas há argumentos que ações desta natureza têm fôlego de curto prazo e que requerem ações de clubes e organizadores do futebol. Outros revelam descrença em relação às ações de órgãos oficiais ou públicos (organizadores do futebol), apostando no setor privado. A partir disso, foi solicitado aos especialistas que se posicionassem a respeito dessas questões. Os resultados obtidos são apresentados a seguir:

Tabela 24: Respostas dos Especialistas (Segunda Rodada) -Ações Iniciativa Privada

\begin{tabular}{|c|c|c|}
\hline & Respostas & Algo a acrescentar? \\
\hline ENT 1 & $\begin{array}{l}\text { Todos devem agir. Além da instituições e empresas provadas, os } \\
\text { próprios clubes e organizadores das competições devem se } \\
\text { responsabilizar por realizar ações como essa. }\end{array}$ & Ambos devem agir \\
\hline ENT 3 & $\begin{array}{c}\text { A evolução do futebol fem está em processo, diferente de } 5 \text { anos } \\
\text { atrás quando estava estagnado e muito mal organizado. Ainda falta } \\
\text { muito a melhorar, ações positivas são bem-vindas independente de } \\
\text { quem é o agente, mas as Instituições oficiais deveriam ser mais } \\
\text { atuantes e até mesmo orquestrar essas ações para o setor público. } \\
\text { Sem sombra de dúvidas a ação do Guaraná foi extremamente } \\
\text { positiva e mostrou que é possível acolher a modalidade em ações } \\
\text { inteligentes e inovadoras. }\end{array}$ & Ambos devem agir \\
\hline ENT 4 & Nada a acrescentar & \\
\hline ENT 9 & Nada a acrescentar & \\
\hline ENT 14 & Acrescentaria os dizeres da ENT 15 à minha. & Ambos devem agir \\
\hline ENT 15 & Nada a acrescentar & Ambos devem agir \\
\hline
\end{tabular}

Fonte: Autoria própria. Dados da pesquisa de campo.

Como a segunda rodada dessa questão estava relacionada ao responsável por essas ações, sejam as instituições e/ou iniciativa privada, não foi possível realizar a tabela com o resultado. Dentre os participantes da segunda rodada, 67\% apontaram que são responsabilidades de ambos e $33 \%$ não se manifestaram. Desta forma, devido ao consenso alcançado, é possível se concluir que a responsabilidade é de todos.

\subsubsection{Casos de sucesso no futebol feminino}

A partir das justificativas apresentadas na primeira rodada a respeito do que os clubes Ferroviária e Corinthians se destacavam dos demais, foi solicitado que os especialistas se posicionassem novamente a fim de obter um maior consenso nas respostas. Na tabela 25 são apresentadas as respostas dos especialistas que participaram da segunda rodada.

Tabela 25: Respostas dos Especialistas (Segunda Rodada) - Casos de Sucesso 


\begin{tabular}{|c|c|c|}
\hline & Respostas & Algo a acrescentar? \\
\hline ENT 1 & $\begin{array}{c}\text { Apesar de não ter muito conhecimento, a estrutura e gestão } \\
\text { profissional desses times possivelmente são acima da média dos } \\
\text { outros, além, é claro, do maior investimento em cima do futebol } \\
\text { feminino }\end{array}$ & $\begin{array}{c}\text { Investimento e Estrutura e Gestão } \\
\text { Profissional }\end{array}$ \\
\hline ENT 3 & $\begin{array}{l}\text { Concordo com a colocação na resposta 9, que ambas as equipes } \\
\text { já estão trabalhando sério antes da obrigatoriedade de os clubes } \\
\text { absorverem o feminino, e por isso já tem um conhecimento maior } \\
\text { da realidade do futebol fem. }\end{array}$ & Investimento \\
\hline ENT 4 & $\begin{array}{l}\text { Acrescentaria um investimento voltado especificamente para essa } \\
\text { modalidade. }\end{array}$ & Investimento \\
\hline ENT 9 & Nada a acrescentar & \\
\hline ENT 14 & $\begin{array}{l}\text { Acredito que seria sim uma janela e que são times com maior } \\
\text { expressão no meio, mais reconhecidos por estes feitos. Porém, } \\
\text { ainda não tenho conhecimento suficiente para opinar. }\end{array}$ & \\
\hline ENT 15 & $\begin{array}{c}\text { Sim, estes exemplos mostram boas estratégia levando em } \\
\text { consideração o potencial do futebol feminino como uma } \\
\text { oportunidade para gerar recursos por meio de patrocínio e } \\
\text { investimentos privados de marcas interessadas em atingir o } \\
\text { público do futebol feminino, principalmente as consumidoras } \\
\text { mulheres. }\end{array}$ & $\begin{array}{l}\text { Futebol Feminino como uma } \\
\text { oportunidade de mercado }\end{array}$ \\
\hline
\end{tabular}

Fonte: Autoria própria. Dados da pesquisa de campo

Tabela 26: Resultado sobre os Casos de Sucesso no Futebol Feminino no Brasil

\begin{tabular}{|c|c|c|c|}
\hline & Investimento & $\begin{array}{c}\text { Estrutura e } \\
\text { gestão } \\
\text { profissional }\end{array}$ & $\begin{array}{l}\text { O feminino } \\
\text { como uma } \\
\text { oportunidade } \\
\text { de mercado }\end{array}$ \\
\hline ENT 1 & 1 & 1 & \\
\hline ENT 2 & 1 & & \\
\hline ENT 3 & 1 & 1 & \\
\hline ENT 4 & 1 & 1 & \\
\hline ENT 6 & 1 & & \\
\hline ENT 8 & 1 & & \\
\hline ENT 9 & 1 & & \\
\hline ENT 10 & 1 & & \\
\hline ENT 11 & & & 1 \\
\hline ENT 12 & & 1 & \\
\hline ENT 13 & 1 & & \\
\hline \multirow[t]{3}{*}{ ENT 15} & 1 & 1 & 1 \\
\hline & 10 & 5 & 2 \\
\hline & $83 \%$ & $42 \%$ & $17 \%$ \\
\hline
\end{tabular}

Fonte: Autoria própria. Dados da pesquisa de campo. 
Conforme é possível verificar na tabela 26, um maior consenso nas justificativas foi encontrado. Excluindo aqueles que apontaram na primeira rodada que não possuem conhecimento e que não participaram da segunda, $83 \%$ dos especialistas apontaram que ambos os times possuem um maior investimento em comparação às demais equipes, $42 \%$ justificaram que eles possuem uma estrutura e gestão profissional diferenciada e $17 \%$ entendem que as equipes olham o futebol feminino como uma oportunidade de mercado. A questão foi encerrada devido ao encontro de um elevado nível de consenso no item "Maior investimento" como explicação para os casos citados.

\subsubsection{Patrocínio nas modalidades feminina e masculina de futebol}

Foram analisadas diferentes razões pelas quais a modalidade feminina de futebol recebe menor atenção e recursos do que a modalidade masculina, no Brasil. O baixo alcance ou visibilidade, baixo retorno dos investimentos, baixo índice de credibilidade, ausência de projetos específicos de patrocínio, falta de interesse por parte da sociedade, preconceito e falta de informação foram os pontos citados na primeira rodada. A partir da visualização das respostas dos outros respondentes e o resumo dos resultados da questão, os especialistas tiveram novamente uma chance para exporem as suas ideias e experiências.

Tabela 27: Respostas dos Especialistas (Segunda Rodada) - Diferenças do Patrocínio entre as Modalidades

\begin{tabular}{|c|c|c|}
\hline & Respostas & Algo a acrescentar? \\
\hline ENT 1 & $\begin{array}{c}\text { Destaco a menor visibilidade e consequentemente o } \\
\text { baixo retorno e a falta de credibilidade }\end{array}$ & $\begin{array}{l}\text { Baixo retorno e a Falta de credibilidade; nivel } \\
\text { organizacional e estrutural ruins }\end{array}$ \\
\hline ENT 3 & $\begin{array}{l}\text { Reitero que o sistema futebol não gera a credibilidade } \\
\text { necessária para mais investimentos de patrocinadores, } \\
\text { mesmo na masculina falta profissionalização. O feminino } \\
\text { precisa melhorar seu produto geral para atrair mais } \\
\text { investimentos, e ter uma maior visibilidade }\end{array}$ & Baixo alcance/visibilidade \\
\hline ENT 4 & Nada a acrescentar & \\
\hline ENT 9 & $\begin{array}{l}\text { Acrescento que há nítida falta de projetos que } \\
\text { evidenciem os benefícios do patrocínio }\end{array}$ & Falta de projeto definido para o patrocínio \\
\hline ENT 14 & Adicionaria as respostas ENT 1, ENT 4, ENT 5 e ENT 10 & $\begin{array}{l}\text { Baixo retorno, Falta de credibilidade; nível } \\
\text { organizacional e estrutural ruins, Falta de } \\
\text { projeto definido para o patrocínio e Falta de } \\
\text { interesse da sociedade }\end{array}$ \\
\hline ENT 15 & $\begin{array}{c}\text { Sim, mais uma vez o pouco alcance e a falta de } \\
\text { visibilidade é um dos fatores dessa menor atenção por } \\
\text { parte das empresas patrocinadoras. }\end{array}$ & Baixo alcance/visibilidade \\
\hline
\end{tabular}


Fonte: Autoria própria. Dados da pesquisa de campo.

Tabela 28: Resultado Final sobre Diferenças do Patrocínio entre as Modalidades de Gênero

\begin{tabular}{|c|c|c|c|c|c|c|c|}
\hline & $\begin{array}{c}\text { Baixo } \\
\text { alcance; } \\
\text { visibilidade }\end{array}$ & $\begin{array}{l}\text { Baixo } \\
\text { retorno }\end{array}$ & $\begin{array}{c}\text { Falta de } \\
\text { credibilidade; } \\
\text { nível } \\
\text { organizacional } \\
\text { e estrutural } \\
\text { ruins }\end{array}$ & $\begin{array}{c}\text { Falta de } \\
\text { projeto } \\
\text { definido } \\
\text { para o } \\
\text { patrocínio }\end{array}$ & $\begin{array}{c}\text { Falta de } \\
\text { interesse } \\
\text { da } \\
\text { sociedade }\end{array}$ & Preconceito & $\begin{array}{c}\text { Falta de } \\
\text { informação e } \\
\text { consequente } \\
\text { subestimação } \\
\text { de potencial }\end{array}$ \\
\hline ENT 1 & 1 & 1 & 1 & & 1 & & \\
\hline ENT 2 & 1 & & & & & 1 & \\
\hline ENT 3 & 1 & 1 & 1 & & & & \\
\hline ENT 4 & 1 & 1 & 1 & & & & \\
\hline ENT 5 & 1 & & 1 & & & & \\
\hline ENT 6 & 1 & & & & & & \\
\hline ENT 7 & & 1 & & & & & \\
\hline ENT 8 & 1 & 1 & & & & & \\
\hline ENT 9 & 1 & & & 1 & & & \\
\hline ENT 10 & 1 & & & 1 & & & \\
\hline ENT 11 & 1 & 1 & & & & & \\
\hline ENT 12 & & & 1 & & & 1 & \\
\hline ENT 13 & 1 & & & & & & \\
\hline ENT 14 & 1 & 1 & 1 & 1 & 1 & & \\
\hline ENT 15 & 1 & 1 & & & & & 1 \\
\hline & 13 & 8 & 6 & 3 & 2 & 2 & 1 \\
\hline
\end{tabular}

Fonte: Autoria própria. Dados da pesquisa de campo.

Os especialistas que participaram da segunda rodada tiveram a oportunidade de realizar comentários adicionais nesse assunto. Conforme é possível analisar na tabela 28, um maior consenso foi alcançado, com destaque para o baixo alcance e visibilidade (87\%). O baixo retorno, com 53\%, e a falta de credibilidade (nível organizacional e estrutural ruins), com 40\%, foram outras razões apresentadas, mas sem nível elevado de confirmação, servindo de tópicos para pesquisas futuras. 
Um fato interessante a se observar é em relação à semelhança do resultado com a questão referente à diferença salarial entre os maiores ícones do futebol brasileiro, onde também a visibilidade e o retorno proporcionados entre as modalidades ficaram nas primeiras posições dentre as justificativas apresentadas. 


\section{Conclusão}

O trabalho tem como objetivo encontrar explicações do porquê o futebol feminino brasileiro receber tão menos atenção e recursos em comparação com a modalidade masculina. Como resultado, pretendeu-se encontrar argumentos que auxiliem no aumento da visibilidade e competitividade da modalidade feminina no Brasil.

Para o embasamento do estudo foi feita revisão de literatura sobre o marketing esportivo e fatores que influenciam o patrocínio esportivo, ambos voltados para o futebol. Além disso, foram apresentados dados importantes do mercado do futebol feminino mais recentes.

A fim de responder à pergunta de estudo, foi realizada uma pesquisa de campo utilizando o Método Delphi. Através de questionários foram realizadas perguntas abertas e fechadas a experts no assunto, com a finalidade de exporem as suas respectivas experiências. Assim, teve como objetivo identificar explicações com elevado nível de consenso por meio de rodadas intercaladas por feedbacks controlados de opiniões dos participantes. Algumas respostas encontraram considerável nível de consenso a partir de duas rodadas de envio das respostas. Com base nesses resultados pode-se concluir o seguinte:

Após analisar os resultados foi possível perceber que avanços na modalidade feminina no futebol vêm ocorrendo nos últimos anos, apesar de sua lentidão. Ainda é visível que existe uma grande discrepância entre as modalidades. Diversos avanços aconteceram, onde os patrocínios representaram uma conquista importante para o futebol feminino que busca por mais valorização.

A sociedade, as empresas patrocinadoras, os times e as instituições possuem um papel fundamental para o crescimento do futebol feminino. Quanto às empresas, vemos iniciativas fantásticas por parte da iniciativa privada em promover o aumento do patrocínio. Em relação aos times, é visível que alguns já estão na frente, com destaque para o Ferroviária e Corinthians com investimentos mais elevados. As instituições, como a FIFA e a CBF possuem também um papel importante para promover a expansão do futebol feminino no Brasil, seja através de imposições legais ou não. Por fim, a sociedade brasileira, que apesar de avanços nos últimos anos, ainda possui o preconceito e o machismo ainda muito enraizado em sua cultura.

Além disso, através das respostas dos formulários foi possível identificar que as empresas patrocinadoras possuem diferentes expectativas ao realizarem essa atividade no 
futebol feminino. Dentre elas, destaca-se o estreitamento de relacionamento com o público, busca de associações à imagem da marca e a obtenção de visibilidade com exposição da marca.

Quando foi questionado as diferenças entre as modalidades masculinas e femininas, os especialistas apontaram a questão da menor visibilidade como fator fundamental responsável por essa discrepância. Os meios de comunicação, na qual possuem uma grande importância no processo decisório das empresas patrocinadoras, dão muito mais visibilidade para a categoria masculina, apesar de avanços significativos nos últimos 10 anos.

Ademais, os especialistas apontaram que a distância do futebol masculino e feminino é fruto de uma construção machista de um século, onde na sociedade brasileira ainda é presente o preconceito com a modalidade feminina. Esse preconceito vem de um histórico, onde no Brasil o Futebol Feminino se desenvolveu muito mais tarde do que nos outros países devido às proibições dos governos na época.

Segundo dados da PNAD Contínua (Pesquisa Nacional por Amostra de Domicílios Contínua) 2019, o número de mulheres no Brasil é superior ao de homens, com aproximadamente $51,8 \%$. Tendo isso em mente e com base nos resultados da pesquisa, recomenda-se uma iniciativa empresarial para alavancar, principalmente para aquelas marcas com produtos destinados ao público feminino. O patrocínio por meio do futebol feminino pode oferecer a exposição de muitas marcas a um público de mulheres que podem ter ficado inacessíveis por meio da modalidade masculina.

Somando-se a isso, seria interessante um cenário contendo subsídios para essas empresas como forma de um "empurrão" para o desenvolvimento da modalidade. A empresa que sair na frente pode ocupar esse espaço vazio que é a marca patrocinadora oficial do futebol feminino brasileiro, ficando reconhecida por ser aquela que ajudou a promover a categoria. Essas ações podem ser consideradas o começo de uma jornada para aumentar a participação das mulheres no futebol.

Além disso, outra sugestão está relacionada à Lei de Incentivo ao Esporte - Lei 11.438/2006, na qual estabelece a possibilidade de pessoas e empresas investirem parte do que pagariam no Imposto de Renda em projetos esportivos aprovados pelo governo. Vemos diversas empresas patrocinando um time ou um determinado esporte. Essas deveriam aproveitar a oportunidade e dividir uma parcela desses investimentos nas modalidades masculinas e femininas. 


\section{Referências Bibliográficas}

AFIF, A. A bola da vez - o marketing esportivo como estratégia de sucesso. São Paulo: Infinito, 2000.

AIDAR, A. C. K.. A nova gestão do futebol. Rio de Janeiro: FGV, 2002.

AIDAR, Carlos; LEONCINI, Marvio; OLIVEIRA, João. A nova gestão do futebol. Rio de Janeiro: FGV. 2000

ALCANTARA, Rodrigo: Futebol feminino bate recordes de audiência em 2020. Bola Vip, dez.2020. Disponível em https://br.bolavip.com/noticias/Futebol-feminino-bate-recordes-deaudiencia-em-2020-20201224-0012.html Acesso em 15 de abril de 2021

ALMEIDA, CAROLINA SOARES O Estatuto da FIFA e a igualdade de gênero no futebol: histórias e contextos do Futebol Feminino no Brasil. FuLiA / UFMG. Belo Horizonte, v. 4, n. 1, p. 72-87, 2019.

BBC. Pelé, 80 anos: como o rei do futebol 'expulsou' um juiz e outras 9 histórias pouco conhecidas. Out 2020. Disponível em https://www.bbc.com/portuguese/geral-

54646183\#: :text=O\%20ex\%2Datleta\%20brasileiro\%20\%C3\%A9,clube\%20e\%20pela\%20S ele\%C3\%A7\%C3\%A3o\%20brasileira. Acesso em 30 de março de 2021.

BELLON Os contratos de patrocínio no futebol e a veiculação das marcas. Disponível em https://ibdd.com.br/os-contratos-de-patrocinio-no-futebol-e-a-veiculacao-das-marcas Acesso 09 de abril de 2021

BENNETT, R. Sports sponsorship, spectator recall and false consensus. European Journal of Marketing, v.33, n.3/4, p. 291-313, 1999.

BENTES, Ariel. Guaraná Antártica vai patrocinar o Brasileirão feminino. Mercadizar, Ago 2020. Disponível em https://mercadizar.com/noticias/guarana-antarctica-vai-patrocinarbrasileirao-feminino/_Acesso em 20 de Março de 2021

BRAND BOLA. Uma breve história do patrocínio no futebol. Disponível em: https://brandbola.com/2020/05/08/uma-breve-historia-do-patrocinio-no-futebol/ Acesso em 01 de Junho de 2021 
BRAND FINANCE: Total Potential of Women 's Football Sponsorship Undervalued by Over US\$1 Billion, jul.2019. Disponível em https://brandfinance.com/press-releases/totalpotential-of-womens-football-sponsorship-undervalued-by-over-us1-billion Acesso em 15 de abril de 2021

BRITTOS, Valério Cruz; SANTOS, Anderson David Gomes dos. Processos midiáticos do esporte: do futebol na mídia para um futebol midiatizado. Comunicação, Mídia e Consumo - Comunicação e Subjetividade. São Paulo: Escola Superior de Propaganda e Marketing, ano 9, v. 9, n. 26., p.173-190, 2012.

BUDOLlA, Marcelo da Silva; SOUZA, Alceu. O patrocínio esportivo como canal de comunicação da estratégia mercadológica: o estudo de caso do Banco do Brasil. In: ENCONTRO ANUAL DA ANPAD (ENANPAD), 29., 2005, Brasília. Anais do XXIX ENANPAD. Brasília: ANPAD, 2005.

CAPITAL CIENTÍFICO. O Policy Delphi como método de pesquisa para o desenvolvimento de framework: o caso dos papéis de promoção do consumo sustentável no contexto brasileiro Disponível em https://revistas.unicentro.br/index.php/capitalcientifico/article/view/5206/html_Acesso em 28 de maio de 2021

CBF. Impacto do futebol brasileiro. Disponível em https://conteudo.cbf.com.br/cdn/201912/20191213172843_346.pdf Acesso 07 de abril de 2021

CBF. CBF apresenta relatório sobre o papel do futebol na economia do Brasil. Dez 2019. Disponível em https://www.cbf.com.br/a-cbf/informes/index/cbf-apresenta-relatorio-sobrepapel-do-futebol-na-economia-do-brasil Acesso 16 de abril de 2021

CHURCHULL, Gilbert A; PETER, J.Paul. Marketing: Criando valor para os clientes. São Paulo: Ed Saraiva, 2000.

CONGENTI Marketing Esportivo no Futebol: Um Estudo das Publicações Sobre Marketing no Meio Futebolístico Brasileiro Disponível em file://C:/Users/mberg/Downloads/8441-30054-1-PB\%20(1).pdf. Acesso em 19 de novembro 2020

CONTURSI, Ernani Benvilaqua. Marketing de Patrocínio. São Paulo: Sprint, 2003. 
CORNWELL, T. B; MAIGNAN, I. An international review of sponsorship research. Journal of advertising, v. 27, n. 1, p. 1-21, 1998.

DA REDAÇÃO. Após queda na indústria do patrocínio esportivo, agências formam consórcio para captar recursos. Caderno informativo 2020 Disponível em: https://www.cadernoinformativo.com.br/apos-queda-na-industria-do-patrocinio-esportivoagencias-formam-consorcio-para-captar-recursos/. Acesso 15 de maio de 2021

DOLIVEIRA, Matheus. Riachuelo assina contrato para patrocinar o futebol feminino . Exame, Nov 2020 Disponível em https://exame.com/casual/riachuelo-assina-contrato-comcbf-para-patrocinar-futebol-feminino/ Acesso 14 de maio de 2021

ELER, Guilherme: A ascensão do futebol feminino. Jun 2019 Disponível em https://super.abril.com.br/especiais/a-vez-do-futebol-feminino/ Acesso em 5 de novembro 2020

ESCOBAR, Roberto. Marketing esportivo aplicado ao futebol: uma fonte de viabilidade econômica. Rio de Janeiro, 2010. 62 p. Monografia, (Economia), Universidade Federal do Rio de Janeiro Disponível em https://pantheon.ufrj.br/bitstream/11422/2544/1/RGEscobar.pdf Acesso em 19 de novembro 2020

ESPM. Patrocínio Esportivo sob a Perspectiva de Gênero. Disponível em https://tede2.espm.br/bitstream/tede/411/2/Sandra\%20Maira\%20Siqueira\%20Naves\%20Leite .pdf Acesso em 28 de maio de 2021

FERA. Audiência do futebol feminino cresceu nos últimos anos, segundo o Ibope. Jul 2019. Disponível em https://esportefera.com.br/noticias/futebol,audiencia-do-futebolfeminino-registra-crescimento-nos-ultimosanos,70002860504\#: :text=Entre\%202014\%20e\%202018\%2C\%20houve,aumento\%20no\%2 0tempo\%20m\%C3\%A9dio\%20assistido. Acesso em 30 de março de 2021.

FERRARI, Débora. Patrocínio Esportivo no Futebol: Convergência das Percepções entre Gestores e Torcedores. FAE, Curitiba, v. 14, n. 1, p. 142-153, jan./jun. 2011

FIRMINO, CAROLINA BORTOLETO A evolução histórica da participação feminina nos Jogos Olímpicos da Era Moderna e a inclusão das mulheres no esporte de competição , Tríade: Revista de Comunicação, Cultura e Mídia: v. 5 n. 10 ,2017. 
FRANCO, Giullya. "História do Futebol"; Brasil Escola. Disponível em: https://brasilescola.uol.com.br/educacao-fisica/historia-do-futebol.htm. Acesso em 30 de março de 2021.

FRANKLIN, Kathy K.; HART, Jan K. Idea generation and exploration: Benefits and limitations of the policy Delphi research method. Innovative Higher Education, v. 31, n. 4, p. 237-246, 2007.

FUTEBOL INTERIOR. Exemplos de sucesso no futebol e fatores a se verificar antes do acordo. Nov 2020 Disponível em https://m.futebolinterior.com.br/noticias/patrociniosexemplos-de-sucesso-no-futebol-e-fatores-a-severificar\#: :text=Outros\%20exemplos\%20de\%20times\%20que,cal\%C3\%A7\%C3\%A3o\%20 do\%20uniforme\%20do\%20clube. Acesso em 14 de abril de 2021

GASPAR, M. A.; MORAIS, D. M. G. VALLADA JÚNIOR, A. C.; DEBIA, C. A. Marketing esportivo: um estudo das ações praticadas por grandes clubes de futebol do Brasil. PODIUM Sport, Leisure and Tourism Review, v. 3, n. 1, p. 12-28, 2014

GASTIN, Vinicius : Escola de Futebol Feminino é aposta para fortalecer modalidade Disponível em https://avozdaserra.com.br/noticias/escola-de-futebol-feminino-e-aposta-parafortalecer-modalidade Acesso em 5 de novembro 2020

GENTE: Linha do tempo do futebol feminino. Jun 2019 Disponível em https://gente.globo.com/linha-do-tempo-do-futebol-feminino/ Acesso em 5 de novembro 2020

GLOBO. Copa do Mundo feminina bate recorde com mais de 1 bi de audiência, out. 2020 Disponível em https://oglobo.globo.com/esportes/copa-do-mundo-feminina-bate-recordecom-mais-de-1-bi-de-audiencia-24026615. Acesso em 15 de abril de 2021

GOAL. Quais são e quanto pagam os patrocínios máster no Brasil? Terra, Jan 2021. Disponível em https://www.goal.com/br/listas/patrocinador-master-times-brasileiros-valoresempresas/jliuotx1769x1grjrvk0q2dcs Acesso 15 de maio de 2021

Grisham, T. (2009). The Delphi technique: a method for testing complex and multifaceted topics. International Journal of Managing Projects in Business, 2(1), 112-130. 
GWINNER, K. A model of image creation and image transfer in event sponsorship. International Marketing Review, v.14, n.3; p. 145-158, 1997.

GWINNER, K. P.; EATON, J. Building brand image through event sponsorship: The role of image transfer. Journal of Advertising, n. 28, vol. 4, p. 47-57, 1999.

GWINNER, K.; BEnNETT, G. The Impact of Brand Cohesiveness and Sport Identification on Brand Fit in a Sponsorship Context. Journal of Sport Management, n.22, p. 410-426, 2008.

HASSON, F.; KEENEY, S.; MCKENNA, H. Research guidelines for the Delphi technique.Journal of Advanced Nursing, v. 32, n. 4, p. 1008-1015, 2000

IBGE. Quantidade de homens e mulheres. Maio 2020. Disponível em https://educa.ibge.gov.br/jovens/conheca-o-brasil/populacao/18320-quantidade-de-homens-emulheres.html\#: :text=Segundo\%20dados\%20da\%20PNAD\%20Cont $\%$ C3\%ADnu,51\%2C8 $\% 25 \% 20 \mathrm{de} \% 20$ mulheres. Acesso 27 Maio 2021

IBOPE REPUCOM. Mapa dos patrocinadores dos clubes da série A do Campeonato Brasileiro Disponível em https://www.iboperepucom.com/media/2019/12/IBOPE-RepucomMapa-do-patroc\%c3\%adnio-2019-Campeonato-Brasileiro-S\%c3\%a9rie-A.pdf Acesso 14 de maio de 2021

IEG SPONSORSHIP. What sponsors want and where dollars will go in . Disponível em http://www.sponsorship.com/IEG/files/f3/f3cfac41-2983-49be-8df6-3546345e27de.pdf Acesso em 14 de abril de 2021

INSIDER SPORT. Two Circles strengthens hospitality capabilities with Sport Ink takeover Jan 2021. Disponível em https://insidersport.com/2021/01/19/two-circlesstrengthens-hospitality-capabilities-with-sport-ink-takeover/. Acesso 16 de abril de 2021

IRWIN, R. L.; LACHOWETZ, T.; CORNWELL, B. e CLARK, J. Cause-related sport sponsorship: an assessment of spectator beliefs, attitudes, and behavioral intensions, Sport 94 Marketing Quarterly, Vol. 12 No. 3, pp. 131-9, 2003. 
JAVALGI, R.; TRAYLOR, M.; GROSS, A.; LAMPMAN, E. Awareness of sponsorship and corporate image: an empirical investigation. Journal of Advertising, v. 23, n.4, p. 47-58, dec. 1994

JENSEN, J. A.; CORNWELL, T. B., 2017. Why Do Marketing Relationships End? Findings from an Integrated Model of Sport Sponsorship Decision-Making, Journal of Sport Management, p. 1-48, 2017.

JORNAL DO COMÉRCIO. Receita do futebol supera 100 milhões e o esporte já é maior que o PIB de 90 países. Porto Alegre, Jul 2018. Disponível em https://www.jornal do commercio.com/_conteudo/esportes/2018/06/631581-receita-do-futebol-supera-r-100bilhões-e-esporte-já-é-maior-que-pib-de-90-países.html Acesso 15 de maio de 2021

LINS Marketing esportivo como estratégia empresarial. Disponível em file:///C:/Users/local_kttiylr/Downloads/Dialnet-

MarketingEsportivoComoEstrategiaEmpresarial-5126471.pdf Acesso em 29 de novembro 2020

MAIS BOLSAS. Futebol: História e Regras. Disponível em https://www.maisbolsas.com.br/enem/educacao-fisica/futebol-historia-e-regras. Acesso em 28 de Abril de 2021

MÁQUINA DO ESPORTE. Nike supera adidas em valor de patrocínios. Jan 2021. Disponível em https://maquinadoesporte.com.br/outros/nike-supera-adidas-em-valor-depatrocinio.Acesso em 20 de Março de 2021

MARKETING ESPORTIVO. Fifa seguirá com investimento de 1 bilhão no futebol feminino. Abr 2020.Disponível em https://www.mktesportivo.com/2020/04/fifa-seguira-cominvestimento-de-us-1-bilhao-no-futebol-feminino/ Acesso em 20 de Janeiro de 2021

MARKETING ESPORTIVO. O mercado e os desafios do patrocínio esportivo. Jan 2018. Disponível em https://www.mktesportivo.com/2018/01/o-mercado-e-os-desafios-dopatrocinio-esportivo/ Acesso 21 de fevereiro de 2021

MARKETING ESPORTIVO. Pesquisa prevê queda de US\$ 17.2 bilhões no patrocínio esportivo. Maio 2020. Disponível em https://www.mktesportivo.com/2020/05/pesquisapreve-queda-de-us-17-2-bilhoes-no-patrocinio-esportivo/ Acesso em 14 de abril de 2021 
MARKETING ESPORTIVO. Subvalorização de patrocínios do futebol feminino é de US \$1.2 bilhão. Jul 2019. Disponível em

https://www.mktesportivo.com/2019/07/subvalorizacao-de-patrocinios-do-futebol-femininoe-de-us-1-2-bilhao/. Acesso em 20 de Janeiro de 2021

MEENAGHAN, T. The role of sponsorship in the marketing communications mix. International Journal of Advertising, v. 10, n. 1, p. 35-47, 1991.

Melo Neto, F. P. de. (2003). Marketing esportivo. Record, Rio de Janeiro

MELO NETO, Francisco Paulo de. Marketing esportivo. Rio de Janeiro: Record, 1995.

MICHAELIS. Dicionário Escolar da Língua Portuguesa. São Paulo: Editora Melhoramentos, 2002. NARDONE, J.; SEE, E.; Measure Sponsorships to Drive Sales. Advertising Age, v.78, n.10, p. 20-21, 2007.

MORAES, Roque. Análise de conteúdo. Revista Educação, Porto Alegre, v. 22, n. 37, p. 732, 1999. Acesso em 25 de maio de 2021

MORETTI, Isabela. O que é análise de conteúdo: 2020 Disponível em https://viacarreira.com/analise-de-conteudo/ Acesso 07 de junho de 2021

MORGAN, M. J.; SUMMERS, J. Marketing Esportivo. São Paulo: Thomson, 2008.

Mullin, B. J., Hardy, S. \& Sutton, W. (2004). Marketing esportivo. Artmed, Porto Alegre

MURAD, Fernando. O patrocínio no mundo do futebol mudou. Meio Mensagem, Abr 2020. Disponível em https://www.meioemensagem.com.br/home/marketing/2020/04/30/opatrocinio-no-mundo-do-futebol-mudou.html Acesso 09 de abril de 2021

NOVO ESPORTE. Tendências de patrocínio no futebol. Jan 2020. Disponível em https://novoesporte.com.br/tendencias-patrocinio-no-futebol/.Acesso 28 de fevereiro de 2021

OLIVEIRA, J. S. P. COSTA, M. M.; WILLE, M. F.C.; MARCHIORI, P. Z. Introdução ao Método Delphi. Curitiba: Mundo Material, 2008

OLIVEIRA, Caio. Mídia Programática: identificação e ranqueamento dos principais problemas e desafios para sua utilização. 2019. Disponível em https://www.maxwell.vrac.puc-rio.br/45847/45847.PDF Acesso em 28 de maio de 2021 
PAIXÃO, Jéssica: Não existe glamour, a invisibilidade do futebol feminino Disponível em https://medium.com/neworder/n\%C3\% A3o-existe-glamour-a-invisibilidade-no-futebolfeminino-b54f2a688c8e Acesso em 5 de novembro 2020

PETROCCHI, Thiago. Marketing de Patrocínio. Mar 2019. Rock Content Disponível em https://rockcontent.com/br/blog/marketing-de-patrocinio/ Acesso 09 de abril de 2021

PITTS, Brenda G; STOTLAR, David K. Fundamentos de marketing esportivo. São Paulo: Phorte, 2002.

POLITIZE. O que a copa do mundo feminina revelou sobre a desigualdade de gênero? Agosto 2019. Disponível em https://www.politize.com.br/copa-do-mundo-feminina-edesigualdade-de-genero/ . Acesso em 19 outubro. 2020

POPE N. K.; VOGES, K. E. The impact of sport sponsorship activities, corporate image, and prior use on consumer purchase intention. Sport Marketing Quarterly, v. 9, n. 2, 2000..

Powell, C. (2003). The Delphi technique: myths and realities. Journal of Advanced Nursing, 41(4), p. 376-382.

POZZI, Luís Fernando. A grande jogada. Teoria e prática do marketing esportivo. São Paulo: Globo, 1998.

PROMOVIEW. Uber é o primeiro patrocinador brasileiro de futebol feminino. Máquina do Esporte, Jul 2019. Disponível em https://www.promoview.com.br/categoria/esportes/ubere-o-1o-patrocinador-do-brasileiro-de-futebol-feminino.html. Acesso 15 de maio de 2021

RAYENS, Mary Kay; HAHN, Ellen J. Building consensus using the Policy Delphi Method. Policy, Politics, \& Nursing Practice, 2000, v. 1, n. 4, p. 308-315.

Rocha, A. da., Ferreira, J. B. \& Silva, J. F. da. (2012). Administração de marketing: conceitos, estratégias e aplicações. Atlas, São Paulo.

ROCHE, F. P. Gestão desportiva - planejamento estratégico nas organizações desportivas. Porto Alegre: Artmed, 2002.

SÁFADI, C. M. Q. Delphi: um estudo sobre sua aceitação. In IV Semed (Seminários de Administração FEA-USP), 2001, São Paulo. Anais. São Paulo: FEA-USP 
SALVINI, L.; MARCHI JÚNIOR, W. "Guerreiras de chuteiras" na luta pelo reconhecimento: relatos acerca do preconceito no futebol feminino brasileiro, Revista Brasileira de Educação Física e Esporte, v. 30 , p. 303-311, 2016.

SANDLER, D. M.; SHANI, D. Sponsorship and the Olympic Games: The consumer perspective. Sport Marketing Quarterly Margaly, v. 2, n. 3, p. 38-43, 1993.

SANTOMIER, J. New media, branding, and global sports sponsorship, International Journal of Sports Marketing \& Sponsorship, Vol. 10 No. 1, p. 15-28, 2008.

SCHARF, E. R.O patrocínio do futebol como ferramenta do marketing esportivo para a construção de brand awareness. Revista Economia \& Gestão, v. 10, n. 23, p. 80-99, 2010.

SCHMIDT, R.; LYYTINEN, K.; KEIL, M.; CULE, P. Identifying Software Project Risks: An International Delphi Study. J. of Management Information Systems. 17, 5-36, 2001.

SCIELO. Método Delphi: caracterização e potencialidades na pesquisa em Educação. Disponível em https://www.scielo.br/scielo.php?pid=S010373072018000200389\&script=sci_arttext Disponível em

SHAW, Sally; AMIS, John M. Image and Investmente: Sponsorship and Womens Sport. Journal Of Sport Management v. 15. DO 10.1123/jsm. 15.3.219. Disponível em file:///C:/Users/local_kttiylr/Downloads/ShawAmis2001JSMImageandinvestment.pdf.

Acesso 26 de maio de 2021

SMOGGI, Amir. Desafios para os patrocinadores em 2021. Sports Value, Jan 2021. Disponível em https://www.sportsvalue.com.br/desafios-para-os-patrocinadores-em-2021/. Acesso 16 de abril de 2021

SOUSA, Eustáquia Salvadora de; ALTMANN, Helena. Meninos e meninas: expectativas corporais e implicações na educação física escolar. Cad. CEDES, Campinas, v. 19, n. 48, p. 52-68, $\quad$ ago. $1999 . \quad$ Disponível em $<$ http://www.scielo.br/scielo.php?script=sci_arttext\&pid=S010132621999000100004\&lng=pt\&nrm=iso.$\quad$ acessos em 28 abr. 2021. https://doi.org/10.1590/S0101-32621999000100004. 
SPORT BUZZ. Maiores patrocinadores do futebol mundial: conheça as empresas que $\begin{array}{llllll}\text { financiam } & 0 & \text { esporte. } & \text { Jan } & \text { Disponível }\end{array}$ https://sportbuzz.uol.com.br/noticias/futebol/maiores-patrocinadores-do-futebol-mundialconheca-empresas-que-financiam-o-esporte.phtml Acesso 28 de fevereiro de 2021

TINGA. Futebol feminino e o diamante a ser lapidado no Brasil. UOL Nov 2020. Disponível em https://www.uol.com.br/esporte/colunas/tinga/2020/11/05/futebol-feminino-eo-diamante-a-ser-lapidado-nobrasil.htm\#: :text=A\%20Nike\%20divulgou\%20em\%202019,das\%2024\%20equipes\%20naqu ele\%20Mundial. Acesso 15 de maio de 2021

TRIVELA. Como o futebol mudou a identidade cultural do brasileiro. Disponível em https://observatorioracialfutebol.com.br/textos/como-o-futebol-moldou-a-identidade-culturaldo-brasileiro/ Acesso 21 de fevereiro de 2021

TUROFF, Murray. The design of a policy Delphi. Technological forecasting and social change, v. 2, n. 2, p. 149-171, 1970.

UNITED NATIONS. Women, gender equality and sport. 2007 Disponível em: . Acesso em: 3 set. 2017.

VERGARA, S. C. Métodos de pesquisa em administração. $3^{\text {a }}$ Ed. São Paulo: Atlas, 2008.

VERGARA, Sylvia Constant. Projetos e relatórios de pesquisa em administração. 3.ed. São Paulo: Atlas, 2009.

Vieira, Bruna. A utilização do marketing esportivo para a valorização de uma marca Revista Científica do Unisalesiano - Lins - SP, ano 3., n.7, jul/dez de 2012 Disponível em http://www.salesianolins.br/universitaria/artigos/no7/artigo24.pdf Acesso em 23 de novembro de 2020

WHEELlER, Brian; HART, Trevor; WHYSALl, Paul. Application of the Delphi technique: A reply to Green, Hunter and Moore. Tourism Management, v. 11, n. 2, p. 121-122, 1990.

WISHART, T.; LEE, S. P.; CORNWELL, T.B. Exploring the relationship between sponsorship characteristics and sponsorship asking price. Journal of Sport Management, v. 26, n. 4, p. 335-349, 2012. 
WRIGHT, J. T. J.; GIOVINAZZO, R. A. Delphi - Uma ferramenta de apoio ao planejamento prospectivo. Caderno de Pesquisas em Administração, São Paulo, v. 01, nº 12, $2^{\circ}$ trim. $/ 2000$.

YAU, Yung; CHIU, Shuk Man. Combating building illegality in Hong Kong: A policy Delphi study. Habitat International, v. 49, p. 349-356, 2015.

\section{Apêndice 1 - Convite Formal}

Prezado(a) Senhor(a):

Estou realizando o trabalho de conclusão de curso de Graduação em Administração na PUC-Rio que tem como objetivo identificar as razões pelas quais o futebol feminino brasileiro recebe menos atenção e recursos do que a modalidade masculina. Assim, busco encontrar explicações para o cenário que revela desigualdades entre essas duas categorias, no Brasil. Devido à sua experiência com o mundo dos esportes, gostaria de convidá-lo(a) para participar dessa pesquisa como especialista.

O trabalho seguirá o método Delphi, o qual requer que cada participante responda um questionário, de forma anônima. As respostas recebidas serão processadas e analisadas em busca de consensos. Quando não forem encontrados consensos entre os experts haverá uma nova rodada de questionamentos para apresentar os argumentos dos demais participantes, quando você poderá ponderá-los e manter ou alterar suas respostas em uma nova rodada. Estima-se que a pesquisa terá, no máximo, 3 fases (rodadas). Cada rodada será mais curta do que a anterior.

Cada questionário deverá ser respondido dentro do período de 3 dias, a contar do seu recebimento. Todos os participantes e suas respostas serão mantidos em sigilo.

O resultado dessa pesquisa será compartilhado com os participantes.

Agradeço antecipadamente por sua atenção.

Mariana Bergier 


\section{Apêndice 2 - Primeira Rodada (Formulário 1)}

Prezado(a) Senhor(a):

Conforme meu último contato, estou realizando um trabalho de conclusão de curso no Departamento de Administração da PUC-Rio. O objetivo é encontrar explicações do porquê o futebol feminino brasileiro recebe tão menos atenção e recursos em comparação com a modalidade masculina. Como resultado, pretende-se encontrar argumentos que auxiliem no aumento da visibilidade e competitividade da modalidade feminina no Brasil. Por conta da sua experiência com o mundo dos esportes, gostaria de convidá-lo(a) para participar dessa pesquisa como especialista!

O trabalho seguirá o método Delphi. As respostas enviadas serão processadas em busca de consensos. Quando não forem encontrados consensos haverá uma nova rodada de questionamentos para apresentar os argumentos dos demais participantes, de forma anônima, quando você poderá ponderá-los e manter ou alterar suas respostas. Estima-se que a pesquisa terá, no máximo, 3 fases (rodadas). Cada rodada será mais curta do que a anterior.

Abaixo o questionário da primeira fase (a mais demorada, rs)! Peço, por gentileza, que as respostas sejam enviadas até o dia 15/05.

Muito obrigado por participar!!

Atenciosamente,

Mariana Bergier

mbergier1@ hotmail.com

$2199982-7798$

\section{Parte 1: Perfil do respondente:}

1) Qual é o seu primeiro nome?

2) Quantos anos de atividade profissional você tem relacionada a esportes?

3) Quantos anos de atividade profissional você tem relacionada ao futebol, em particular?

4) Sobre atividades relacionadas a patrocínio, você já teve alguma? 
( ) Sim ( ) Não

Em caso afirmativo, por quantos anos?

5) Ainda em caso afirmativo, essas atividades com patrocínio tiveram relação com o futebol? ( ) Sim ( ) Não

Em caso afirmativo, por quantos anos?

6) Quantos anos de atividade profissional você tem/teve envolvido com patrocínio no futebol feminino?

\section{Parte 2: Sobre o futebol feminino no Brasil}

7) Com base em sua experiência, a que você atribui a expectativa de retorno das empresas ao patrocinarem o futebol no Brasil? Considere as opções abaixo e marque quantas julgar aplicáveis.

( ) Buscar associações à imagem da marca

( ) Estreitamento de relacionamento com os clubes

( ) Estreitamento de relacionamento com outras empresas

( ) Estreitamento de relacionamento com o público

( ) Obter visibilidade com exposição da marca

( ) Possibilidade de aumento nas vendas

( ) Se diferenciar da concorrência

( ) Obter vantagens fiscais

( ) Atender desejos pessoais dos executivos

( ) Outro: Favor especificar

8) Segundo dados divulgados pela revista americana Forbes em 2019, Marta, eleita pela FIFA seis vezes como a melhor jogadora de futebol do mundo, recebe de salário anual cerca de US\$400 mil. Neymar, jogador brasileiro com maior projeção internacional, embora não tenha sido eleito pela FIFA ainda como melhor jogador do mundo, recebe US\$17 milhões, vindos apenas de publicidade e patrocínio. Em sua opinião, o que explica essa diferença? 
9) Comparando o futebol feminino com a categoria masculina, como você classifica o papel da imprensa e dos veículos de comunicação quanto à divulgação da modalidade feminina?
( ) Excelente
( ) Boa
( ) Regular
( ) Ruim
( ) Péssima

10) Como você classifica o nível de importância da exposição nas mídias (imprensa e veículos de comunicação em geral) do futebol feminino no processo decisório das empresas de patrocinarem a modalidade neste gênero?

( ) Muito Importante

( ) Importante

( ) Indiferente

( ) Alguma importância

( ) Nada Importante

11) Como você classifica o nível de atuação da imprensa e dos veículos de comunicação na cobertura do futebol feminino brasileiro atualmente em comparação a 10 anos atrás?

( ) Aumentou muito

( ) Aumentou um pouco

( ) Não houve alteração significativa

( ) Diminuiu um pouco

( ) Diminuiu muito

12) Segundo o relatório anual publicado pela Brand Finance em 2019, no âmbito mundial a categoria feminina de futebol tem uma subvalorização de seus patrocínios avaliada em aproximadamente US \$1.2 bilhão, em comparação ao masculino. Em sua opinião, o que explica isso? 
13) Dentre as marcas patrocinadoras do futebol feminino, destaca-se a Guaraná Antártica. Em 2020 a marca lançou uma campanha incentivando o futebol feminino, provocando as demais marcas a fazerem o mesmo. A Cia Antártica prometeu dividir/substituir a exposição de sua marca nas placas de publicidade nas laterais dos gramados por frases de apoio/incentivo ao futebol feminino. Você acredita que este tipo de ação é um caminho para o crescimento do patrocínio no futebol feminino? Por favor, justifique sua resposta.

14) No futebol feminino brasileiro destaca-se o time do Ferroviária, clube do interior de São Paulo. O mesmo já foi campeão 1 vez da Copa do Brasil, 2 vezes campeão do Brasileirão e 2 vezes campeão das Libertadores, enquanto que a sua equipe masculina nunca conquistou nenhum título dos campeonatos citados. O Corinthians, por sua vez, na categoria feminina foi campeão 2 vezes pela Libertadores, 2 vezes campeão do Brasileirão, 2 vezes campeão do Paulistão e 1 vez campeão da Copa do Brasil. Na categoria masculina foi campeão 2 vezes da Copa do Mundo de Clubes da FIFA, 1 vez campeão das Libertadores, 7 vezes campeão do Brasileirão e 3 vezes campeão da Copa do Brasil. Considerando suas performances no âmbito do futebol feminino, em que esses dois clubes se destacam dos demais?

15) Há, por parte da CBF, movimentos para tentar diminuir as diferenças entre os gêneros no futebol. Uma dessas ações foi o novo regulamento publicado em 2019, determinando que todas as equipes da primeira divisão do Campeonato Brasileiro Masculino tenham um time feminino adulto e, pelo menos, uma categoria de base. Em sua opinião, o futebol feminino brasileiro precisa de imposições legais para se desenvolver e ser valorizado? Por favor, justifique sua resposta:

16) Sendo o Brasil conhecido como o país do futebol, em sua opinião, há preconceito no cenário do futebol brasileiro ao se observar tantas diferenças de divulgação e investimentos entre as categorias feminina e masculina? Por favor, comente:

17) Segundo sua experiência, quais são os principais motivos pelos quais empresas patrocinadoras da modalidade de futebol masculina não patrocinam a modalidade feminina?

\section{Apêndice 3 - Segunda Rodada (Formulário 2)}

\section{Prezada XXX,}

Muito obrigado por sua participação na primeira etapa de minha pesquisa!! Conforme explicado no último e-mail enviado, o trabalho segue o método Delphi. Nesta segunda rodada 
serão reapresentadas as questões (5, especificamente) que não obtiveram consenso nas respostas, os respectivos argumentos apresentados, bem como o resultado sintetizado de cada questão, a partir das respostas dos participantes. A partir delas, você vai poder comentar, manter ou alterar suas considerações.

Agradeço antecipadamente, mais uma vez, por sua participação.

Orientações Gerais:

1) Você está recebendo a seguir as questões que não alcançaram consenso, assim como uma síntese das respostas atribuídas a elas.

2) Em destaque você verá a íntegra de suas respostas a cada uma dessas perguntas. Solicito que pondere sobre as respostas e argumentos apresentados pelos demais experts e, a partir delas, avalie se há algo mais a considerar em sua resposta, conforme apresentada originariamente. De novo, você tem liberdade para mantê-la como está, complementá-la ou alterá-la.

3) Para cada questão, apresento duas folhas contendo: pergunta do primeiro formulário, quadro com as respostas de todos os participantes da pesquisa de forma anônima (inclusive a sua), quadro com o resumo das respostas, "nova pergunta". No final de cada questão, peço por favor para inserir as suas considerações.

O prazo para o encerramento da segunda fase é até o dia 23/05.

Atenciosamente,

Mariana Bergier

(21 99982-7798)

Pergunta 1 da segunda rodada: Esta questão tinha como foco a discrepância de renda entre dois jogadores brasileiros de destaque no futebol, ambos de renome internacional, mas de gêneros distintos. Ela, com maior número de prêmios internacionais; ele com maior faturamento. As explicações apresentadas por cada participante estão expostas conforme o quadro acima *. Sua resposta foi a seguinte: "XX"

De acordo com a síntese das respostas obtidas você teria algo mais a acrescentar ou algo a reconsiderar em sua resposta? Em caso afirmativo, por favor, utilize o espaço abaixo:

Pergunta 2 da segunda rodada: Embora semelhante em natureza à pergunta anterior, esta questão tinha como foco a discrepância de valor percebido entre as duas modalidades de futebol: masculino e feminino. As explicações apresentadas por cada participante estão expostas conforme o quadro acima*. Surge neste conjunto de respostas argumentos de que a diferença de valor percebido por patrocinadores, além da já comentada falta de visibilidade, se deve, em parte, à não atratividade do futebol feminino junto ao público em geral, embora na última Copa do Mundo realizada no Brasil o esquete feminino gerou grande admiração e envolvimento junto ao público em geral. Seria o caso de haver de fato menor atratividade 
nesta modalidade ou seria o menor valor um efeito de sua menor exposição/visibilidade? Sua resposta foi a seguinte: "XX"

De acordo com a síntese das respostas obtidas você teria algo mais a acrescentar ou algo a reconsiderar em sua resposta? Em caso afirmativo, por favor, utilize o espaço abaixo:

Pergunta 3 da segunda rodada: Esta pergunta recorreu a um exemplo de uma iniciativa individual, uma empresa/marca privada, como incentivadora a outras marcas para participarem como patrocinadoras do futebol feminino. As explicações apresentadas por cada participante estão expostas conforme o quadro acima*. Surge neste conjunto de respostas um consenso em relação aos méritos de tal ação. Contudo, no conjunto das respostas há argumentos que ações desta natureza têm fôlego de curto prazo e que requerem ações de clubes e organizadores do futebol. Outros revelam descrença em relação às ações de órgãos oficiais ou públicos (organizadores do futebol), apostando no setor privado. Sua resposta foi a seguinte: " $X X$ "

De acordo com a síntese das respostas obtidas você teria algo mais a acrescentar ou algo a reconsiderar em sua resposta? Em caso afirmativo, por favor, utilize o espaço abaixo:

Pergunta 4 da segunda rodada: Esta pergunta recorreu a um exemplo de dois clubes brasileiros de futebol, com expressões bem distintas na modalidade masculina, mas ambos com grandes feitos na modalidade feminina. Neste caso, em especial, o de menor expressão na modalidade masculina e no âmbito nacional, Ferroviária, tem títulos nacionais e internacionais. O que os difere, no âmbito feminino, dos demais clubes de futebol no Brasil? As explicações apresentadas por cada participante estão expostas conforme o quadro acima. Surge neste conjunto de respostas argumentos que investimentos consistentes, profissionalização e infraestrutura adequada geram tais resultados. Não seria este também um exemplo do potencial do futebol feminino e uma janela de oportunidades para marcas e patrocinadores interessados no público feminino, maior parcela da população brasileira? (IBGE, 2010). Sua resposta foi a seguinte: " $X X$ "

De acordo com a síntese das respostas obtidas você teria algo mais a acrescentar ou algo a reconsiderar em sua resposta? Em caso afirmativo, por favor, utilize o espaço abaixo:

Pergunta 5 da segunda rodada: Esta pergunta procurou reforçar, de modo mais enfático, as razões pelas quais a modalidade feminina de futebol recebe menor atenção e recursos do que a modalidade masculina, no Brasil. As explicações apresentadas por cada participante estão expostas conforme o quadro acima*. Revelam-se neste conjunto de respostas diversos argumentos que incluem: baixo alcance ou visibilidade (maioria), baixo retorno dos investimentos, baixo índice de credibilidade, seja por nível organizacional, seja por serem "produtos" ruins, ausência de projetos específicos de patrocínio, falta de interesse por parte da sociedade, preconceito e falta de informação, o que leva à subestimação dos potenciais engajamentos das marcas com o público desta modalidade. Sua resposta a esta pergunta foi a seguinte: " $X X$ "

De acordo com a síntese das respostas obtidas você teria algo mais a acrescentar ou algo a reconsiderar em sua resposta? Em caso afirmativo, por favor, utilize o espaço abaixo: 
*Em todas as questões foram apresentadas as respostas dos participantes da primeira rodada de forma anônima, bem como o quadro resumo. 